OECDpublishing

\title{
VULNERABILITY \\ OF SOCIAL INSTITUTIONS
}

OECD ECONOMIC POLICY PAPER

July 2014 No. 11 


\section{Vulnerability of Social Institutions}

This paper was prepared by:

Falilou Fall

Debbie Bloch

Peter Hoeller

Jon Pareliussen

Mauro Pisu

Authorised for publication by Jean-Luc Schneider, Deputy Director, Policy Studies Branch, Economics Department 
The OECD Economic Policy Paper Series is published on the responsibility of the Secretary-General of the OECD. This paper is published under the responsibility of the Secretary-General of the OECD. The opinions expressed and the arguments employed herein do not necessarily reflect the official views of OECD member countries.

An earlier version of this paper was discussed at the Working Party No. 1 of the OECD

Economic Policy Committee. The authors would like to thank the participants.

More detailed information is available from the following:

Fall, F., M. Pisu, J. Pareliussen and D. Bloch (2014), Vulnerability of Social Institutions: Lessons from the Recent Crisis and Historical Episodes, OECD Economics Department Working Papers, No. 1130

Pareliussen, J. (2014), Overcoming Vulnerabilities of Unemployment Insurance Schemes, OECD Economics Department Working Papers, No. 1131.

Pisu, M. (2014), "Overcoming Vulnerabilities of Health Care Systems", OECD Economics Department Working Papers, No. 1132.

Fall, F. and D. Bloch (2014), "Overcoming Vulnerabilities of Pension Systems", OECD Economics Department Working Papers, No. 1133.

Fall, F. (2014), "Comparing the Robustness of PAYG Pension Schemes", OECD Economics Department Working Papers, No. 1134.

Series: OECD Economic Policy Papers

ISSN $2226583 \mathrm{X}$

This document and any map included herein are without prejudice to the status of or sovereignty over any territory, to the delimitation of international frontiers and boundaries and to the name of any territory, city or area.

The statistical data for Israel are supplied by and under the responsibility of the relevant Israeli authorities. The use of such data by the OECD is without prejudice to the status of the Golan Heights, East Jerusalem and Israeli settlements in the West Bank under the terms of international law.

\section{๑) OECD 2014}

You can copy, download or print OECD content for your own use, and you can include excerpts from OECD publications, databases and multimedia products in your own documents, presentations, blogs, websites and teaching materials, provided that suitable acknowledgment of OECD as source and copyright owner is given. All requests for public or commercial use and translation rights should be submitted to rights@oecd.org. Requests for permission to photocopy portions of this material for public or commercial use shall be addressed directly to the Copyright Clearance Center (CCC) at info@copyright.com or the Centre français d'exploitation du droit de copie (CFC) at contact@cfcopies.com. 


\section{Table of contents}

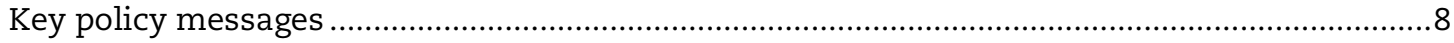

Overcoming vulnerabilities of pension systems ……………...............................................

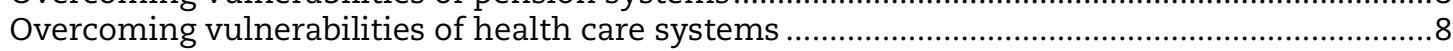

Overcoming vulnerabilities of unemployment insurance systems .............................................9

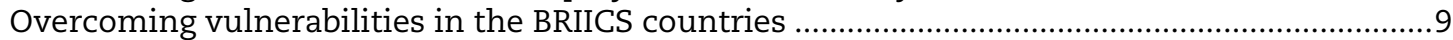

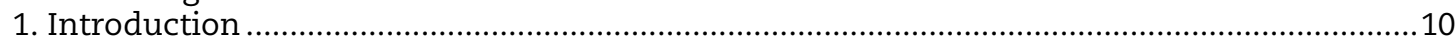

2. Shocks and adaptability: A framework for the analysis ..........................................................10

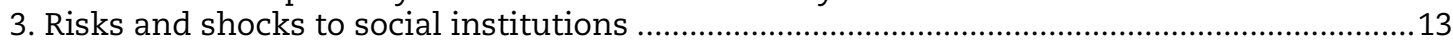

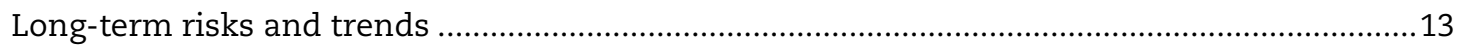

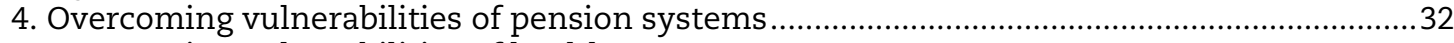

5. Overcoming vulnerabilities of health care systems ..................................................................42

6. Overcoming vulnerabilities of unemployment insurance schemes .........................................47

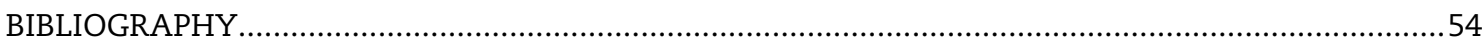

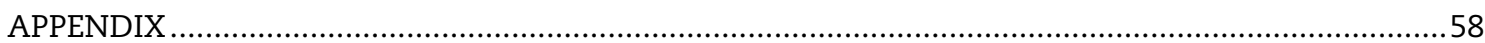

Tables

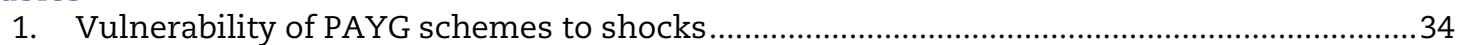

2. Reforming PAYG schemes to cope with the ageing shock ...................................................36

3. Automatic adjustment mechanisms to ensure the sustainability of pension schemes......38

A1. Social spending before and after the crisis .........................................................................58

Figures

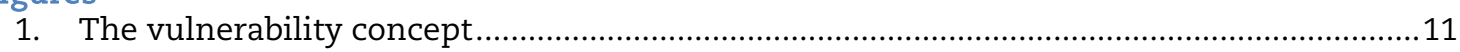

2. Schematic example of the sustainability and adequacy trade-off........................................13

3. The old-age support ratio will halve in the OECD and by more in some BRIICS countries 14

4. The impact of future health and pension spending on consolidation needs.........................14

5. Health status in old age affects public health care spending ..............................................16

6. The public health spending to GDP ratio is little affected by productivity changes............17

7. Price and technological developments affect the public health spending-to-GDP ratio ....18

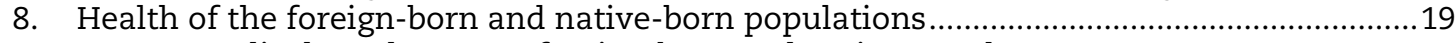

9. Unmet medical needs among foreign-born and native people ...............................................2

10. Unemployment rates are often higher among immigrants than natives.............................21

11. Volatility index of social protection systems' revenues .........................................................23

12. Hike in effective VAT rate needed to replace social security contributions ...........................24

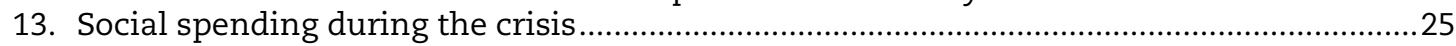

14. Unemployment and ALMP spending before and during the initial phase of the crisis ......26

15. Unemployment, volatility and expenditure response .............................................................22

16. Vulnerability of unemployment insurance schemes to GDP shocks...................................29

17. The vulnerability of public health spending to GDP shocks is modest in most countries .30

18. Average real net investment return of pension fund assets.................................................... 31

19. Real disposable income shocks affect private health insurance coverage ............................45

20. Health care spending is low in the BRIICS countries ........................................................46

21. Youth poverty has soared during the crisis, while older people were better protected ......48

22. The responsiveness of active labour market policies to unemployment .............................50 
23. Employment and unemployment of older workers ..........................................................5 51

24. Affiliation to social security by earnings quintile in lower income countries.........................53

Boxes

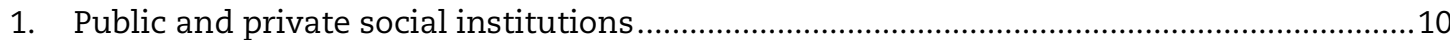

2. Short-run shocks and the financing of social institutions.................................................22

3. GDP shocks can lead to an upward creep in unemployment

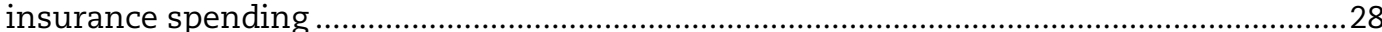

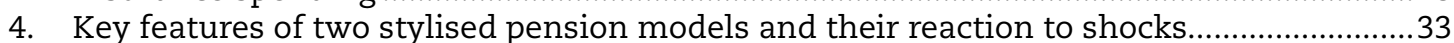

5. Pension reforms to cope with an ageing shock ..............................................................36

6. Political economy of reforms: Independent bodies and consensus building .....................39

7. Review of policies to contain the secular increase in health care spending ......................43 


\section{Abstract / Résumé \\ Vulnerability of social institutions}

Social institutions face many challenges. The recent economic crisis has provided a stress test as it has left a legacy of high unemployment and high government debt in many countries. It also lowered potential output and thus the revenue base for social protection schemes. At the same time, ageing and other secular trends raise long-term sustainability issues. The design of social institutions determines their capacity to deal with shocks and trend changes and the way risks are shared between the institutions and their stakeholders. They also circumscribe the scope for automatic or discretionary adjustments, when trade-offs between sustainability, adequacy and efficiency arise. This report examines the sustainability of social institutions and their ability to absorb and cope with short-term shocks and longer-term trends by providing risk sharing and expenditure smoothing, focusing on pension, health care and unemployment insurance schemes.

JEL classification codes: H51; H53; H55; I13; I38; J11; J26; J65

Keywords: Social protection, health care, pension schemes, unemployment insurance

\section{Vulnérabilité des institutions sociales}

Les systèmes de protection sociale sont confrontés à de nombreux défis. La récente crise économique a été un test de robustesse avec son lot de chômage élevé et de hausse de la dette publique dans de nombreux pays. La crise a également réduit le PIB potentiel et donc la base de financement des régimes de protection sociale. Dans le même temps, le vieillissement et les autres tendances séculaires soulèvent des questions de durabilité financière à long terme. Les caractéristiques structurelles des institutions sociales déterminent leur capacité à faire face aux chocs et aux changements de tendance, et également le partage des risques entre les institutions et leurs parties prenantes. Elles définissent aussi la possibilité d'ajustements automatiques ou discrétionnaires lorsqu'il faut faire des arbitrages entre la durabilité financière, l'adéquation des services et des gains d'efficacité. Ce rapport examine la viabilité des institutions sociales et leur capacité à absorber et à faire face aux chocs à court terme et aux tendances de long terme par le partage des risques et le lissage des dépenses, en se concentrant sur les régimes de retraite, de soins de santé et d'assurancechômage.

Classification JEL : H51 ; H53 ; H55 ; I13 ; I38 ; J11 ; J26 ; J65

Mots clés: Protection sociale, santé, retraite, assurance chômage 


\section{Vulnerability of Social Institutions}

Key policy messages

- Social institutions, especially unemployment insurance, shelter individuals from the full effects of adverse, temporary shocks through risk sharing and play a useful role as automatic stabilisers.

- In the long run, policy settings of social institutions need to be adjusted to cope with permanent shocks and trend changes.

- The design of social institutions determines their capacity to deal with shocks and trend changes, the way risks are shared between the institutions and their stakeholders, and the scope for automatic or discretionary adjustments, when trade-offs between sustainability, adequacy and efficiency arise.

\section{Overcoming vulnerabilities of pension systems}

- PAYG pension schemes face sustainability issues in many countries. They are exposed to ageing and uncertainties surrounding future productivity trends. Funded pension schemes are affected by interest rate, asset price and longevity risks.

- Increasing the retirement age is more efficient to balance PAYG pension schemes, including defined-contribution point schemes, while preserving pension adequacy, than increasing the contribution rate or decreasing the pension rate. However, raising the retirement age is not sufficient, if options for early retirement exist; the employment of older workers needs to be facilitated.

- Adjusting key parameters automatically to trend changes enhances the financial robustness of pension systems. The adjustment can link the pension level, the retirement age, the contribution period or a combination of them to life expectancy.

- To ensure adequacy in the future and avoid ageing costs unduly weighing on social budgets, widening the coverage of voluntary private pensions should be a prime objective in countries where they represent an important complement to (relatively low) public pensions.

\section{Overcoming vulnerabilities of health care systems}

- Health care spending could rise considerably in the future due to price and technology developments. Some policy reforms to contain the secular rise in health spending face sustainability-adequacy trade-offs, whereas others do not. For instance, high cost sharing can help curb public spending, but also worsen adequacy. Tax incentives for private health insurance enrolment are often regressive and ineffective in reducing spending.

- On the other hand, regulated competition among health care service providers, well-designed budgetary caps, hospital payments based on diagnostic related groups and health technology assessments can improve sustainability without damaging the adequacy of services.

- Reforms aimed at enhancing the efficiency of the health care sector could generate large savings and partly offset future spending pressures, thus easing the sustainability-adequacy trade-off. 


\section{Overcoming vulnerabilities of unemployment insurance systems}

- The recent crisis has led to soaring unemployment in many countries. Generous benefits, long duration and high coverage generate large spending spikes during a severe downturn and can create disincentives to work. On the other hand, stringent eligibility criteria or very short benefit duration can jeopardise the core functions of unemployment insurance as a tool for risk sharing and efficient reallocation of labour.

- Trade-offs can be eased. For instance, an effective labour activation policy can reduce spending on unemployment benefits and, by getting people back to work, buttresses government revenues.

- Contingency plans should be in place to cope with a surge in unemployment. Activation policies should be scaled up during crises. Temporary extensions of unemployment benefit duration and temporary loosening of eligibility criteria may play a useful role in countries where duration is low and access to social assistance is limited.

\section{Overcoming vulnerabilities in the BRIICS countries}

- For most BRIICS countries, the low adequacy provided by social institutions, or even complete absence of institutional risk sharing for a large part of the population, is the main issue. The prevalence of the informal sector with many low income earners is the most important barrier to providing adequate social risk coverage for all. 


\section{Introduction}

Individual risk protection is the most important function of social protection schemes, be they public or private. The recent economic crisis has provided a stress test for these schemes as it has left a legacy of high unemployment and high government debt in many countries. It also lowered potential output and thus the revenue base for social protection schemes. At the same time, ageing and other secular trends raise long-term sustainability issues. This paper examines the sustainability of social institutions and their ability to absorb and cope with short-term shocks and longer-term trends by providing risk sharing and expenditure smoothing, focusing on pension, health care and unemployment insurance schemes.

If shocks and trends necessitate reforms to social protection schemes, this can raise trade-offs between the sustainability of the systems and the generosity of benefits. However, there can also be synergies. Higher employment, for instance due to longer working lives, can ease constraints because it reduces spending on pensions and provides more funding for other social protection schemes. Challenges differ between the OECD countries, which have a well-developed welfare state, where ensuring sustainability is often the most important policy challenge and the BRIICS countries, where raising the adequacy of social protection is often the most burning issue.

The remainder of this paper is structured as follows. Section 2 presents the framework for analysing the vulnerability of social institutions. Section 3 focuses on the short and long-run shocks to which social institutions are exposed. In Sections 4, 5 and 6, policies to overcome vulnerabilities of pension, health care and unemployment insurance schemes are presented.

\section{Shocks and adaptability: A framework for the analysis}

Social institutions protect individuals from risks, such as losing a job, suffering from a disease or incurring large income or saving losses. These events can lead to large welfare losses as they do not only affect people's current living conditions but also their future income and well-being. Because it is virtually impossible for individuals to cope with all of the risks they face on their own, risk sharing is a central purpose of social institutions (Box 1). However, in case of large negative shocks or if the effects of adverse trends go unaddressed, social institutions may become unable to continue to perform their core functions. This may lead to lower benefits, higher contributions or even default. The vulnerability of social institutions can be analysed along three dimensions: i) the types of adverse shocks social institutions face; ii) the institutional capacity to absorb, cope with and recover from shocks; iii) and the outcomes or promises of social institutions, such as expected services or transfer payments (Figure 1).

\section{Box 1. Public and private social institutions}

Social protection can be provided by the private or public sector or a mixture of both (Barr, 2012).

Family-based social institutions: They mainly provide intra and inter-generational redistribution of resources among family members. This can take the form of supporting and caring for children and the elderly besides offering a safety net - in case of job loss and illness - to other adult family members and provide thus the protection of last resort, when other institutions fail. While declining in importance, the family is still an important form of social institution, in particular in some BRIICS countries. In the face of liquidity constraints, the effectiveness of family-based insurance is limited, especially among the poor.

Market-based social institutions: The main purpose of private insurance is risk sharing among participants. Even defined-contribution pension schemes provide risk sharing as they allow participants to share longevity risks. Private insurance markets work well, if individuals are fully informed and rational, there are no market failures and when shocks are idiosyncratic. The larger the pool of participants, the greater the likelihood that risks are not correlated. When these conditions are not met, the design of private social institutions becomes more complex. In the presence of market failures, such as moral hazard, adverse selection or insufficient property rights, markets for some risks 
may not exist or function poorly. For instance, private unemployment insurance hardly exists because of severe moral hazard and adverse selection problems. Also, the insurance market for long-term care has struggled to develop, because of uncertainty surrounding the costs of an event that will take place in the distant future and people's aversion to get insured for such risks - an example of myopic behaviour or bounded rationality (Brown and Finkelstein, 2007; Johnson and Uccello, 2005). On the other hand, private health insurance and pension markets are well developed in several OECD countries, but sound regulation of private insurance is necessary to mitigate the adverse effects of market failures.

State-based social institutions: Public social institutions often provide risk sharing and some redistribution at the same time, through a variety of cash and in-kind benefits. Public insurance schemes complement or substitute for those provided by markets depending on the prevalence of market failures. The scope for public provision is largely affected by two factors: as for private provision, insurance can lead to moral hazard, while adverse selection problems do not exist, if a scheme is mandatory. In addition, incentive problems can arise and the settings of schemes need to strike a balance between providing insurance and adverse incentives effects (Chetty and Finkelstein, 2012).

State based social institutions also aim at lowering inequality and offer poverty relief. Poverty relief and redistribution are important, especially for the less well-off, because they have little or no savings to cushion income shortfalls and because they can prevent permanent damage to human and social capital (Barr, 2012). However, the extent and form of redistribution are grounded in views about social justice and therefore vary markedly across countries.

Non-profit social institutions: They are independent of government, but may be partly financed by it. They provide services, such as running hospitals and social insurance (health care, pension). As market institutions, they provide risk-sharing for their members.

Figure 1. The vulnerability concept

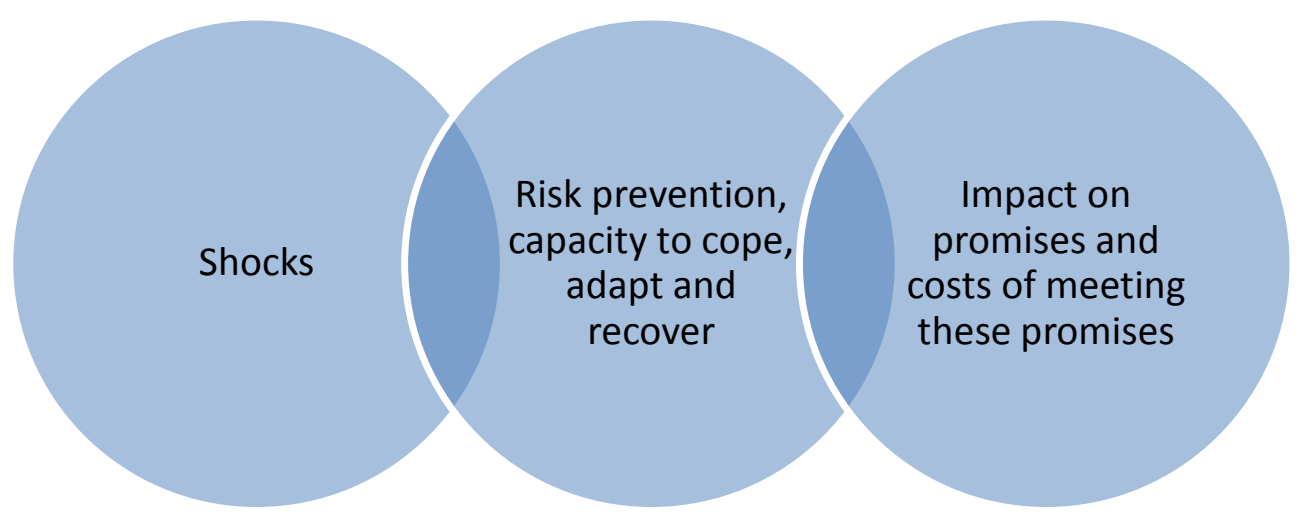

The analysis focuses on three main social protection schemes: health care, pension schemes and unemployment insurance. On average across the OECD, these schemes account for more than $70 \%$ of total social spending (Table A1). These institutions are exposed to shocks affecting their spending and financing. As public social institutions are in general financed by social insurance contributions or tax revenues, GDP slumps and sharp unemployment increases can trigger financial distress of social institutions. Private social institutions (pension funds, private health insurance) are more exposed to financial markets risks. Pension fund investment strategies can cope with idiosyncratic risks, but are still vulnerable to aggregate risk or covariance in risks. 
Vulnerabilities also arise because of secular trends. Ageing will put increasing pressure on social institutions both on the spending and financing side. Other structural trends such as globalisation via trade and financial integration raise overall welfare, but these gains may not be widely shared or raise the variability of outcomes. Future productivity developments are uncertain and lower productivity growth could affect social institutions through various channels. Although immigrants tend to adopt the behaviour of residents and become beneficiaries in the same way, changes in migration trends can affect the outlook of social institutions. New OECD simulations of bilateral international migration flows over the period to 2060 suggest that the OECD may experience net emigration of economic migrants between 2010 and 2060 (OECD, 2014). This will affect dependency ratios and unemployment rates.

In reacting to shocks, reforms need to balance sustainability, adequacy and efficiency considerations

The economic literature has long investigated the optimal design of social institutions and the role of public policies so as to best trade off individual risk protection with minimising moral hazard (e.g. Chetty and Finkelstein, 2012). The main lesson from these studies is that the characteristics of welfare-maximising social institutions are context specific as they depend on the existence, extent and types of market failures. In addition, most of the policy-oriented studies focus on marginal changes in the arrangement of existing programmes, such as the optimal level of benefits given their current structure, and are silent about more drastic policy changes and how to make social institutions more resilient to large aggregate shocks.

Irrespective of specific design issues, reforms of social protection systems need to balance their long-term economic sustainability and adequacy of services (Figure 2):

Sustainability refers to the matching of spending with revenues over the medium to long term. It is a key characteristic of resilient social protection systems, because unsustainability will either lead to a curtailing of benefits and thus a weakening of social protection or an ever rising tax burden, which undermines efficiency and thus the revenue base of social protection systems.

Adequacy refers to the coverage, generosity and equity of benefits or services received. Following a shock that undermines sustainability, a reduction of the coverage of services or of the generosity of transfers enhances sustainability at the expense of adequacy.

Adverse shock can make the trade-off between sustainability and maintaining adequacy more acute. If hit by aggregate shocks undermining the sustainability of their social protection systems countries lying close to the sustainability-adequacy frontier ( $\mathrm{A}$ and $\mathrm{B}$ in Figure 2) may have to implement deep cuts in adequacy to preserve the sustainability of the system. Global shocks (such as a general adverse productivity shock) could move the frontier inward, affecting both the sustainability and adequacy of social protection systems negatively. On the other hand, deep policy reforms and technological developments can lead to improvements in both sustainability and adequacy by shifting the frontier outward.

Policy settings outside the social protection schemes are also important. Macroeconomic and structural policies influence the size of shocks, their amplitude and their persistence. Recent work for EPC (Sutherland and Hoeller, 2014) has shown complementarities and trade-offs between various policy levers that promote growth and those that promote macroeconomic stability. Moreover, the existence of fiscal space provides a shock absorber in times of crisis, while well-functioning labour markets are important, as high employment rates provide a more ample revenue base for social insurance systems. Finally, social institutions can interact. For example, decisions about retirement can be influenced by the design of the unemployment scheme or health care coverage. 
Figure 2. Schematic example of the sustainability and adequacy trade-off

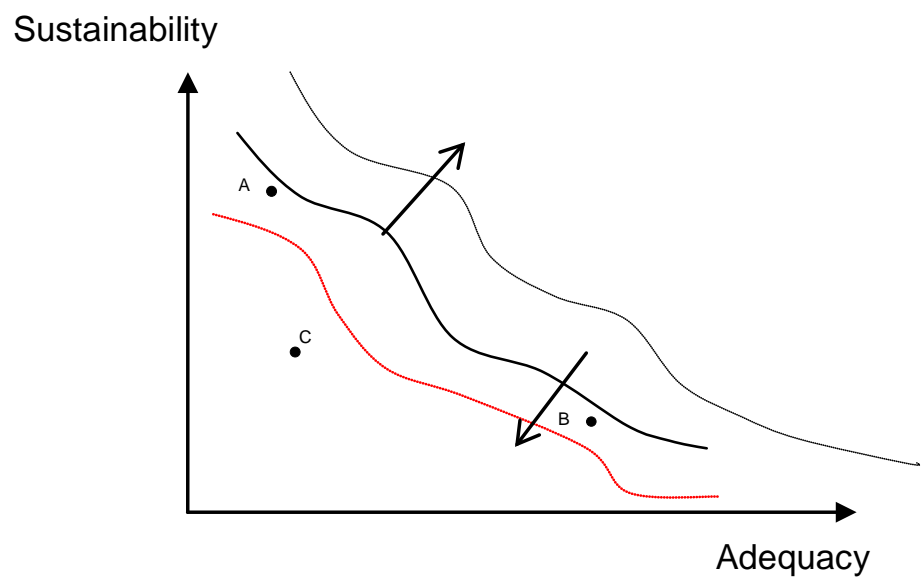

\section{Risks and shocks to social institutions}

This section reviews the vulnerability of health and unemployment insurance schemes to longterm risks and trends as well as to various short-term shocks. It also assesses the vulnerability of funded pension schemes to ageing and financial market risks. The analysis of the vulnerability of PAYG pension schemes will be deepened in the next section, and discussed together with reform options.

\section{Long-term risks and trends}

\section{Demographic trends and the outlook for social institutions}

\section{Demographic developments and their fiscal effects}

Rising life expectancy and decreasing fertility rates will reduce the old-age support ratio (working-age population over those older than 65 years) from 4.2 currently to 2.1 in 2050 in the OECD on average and the decline will be even more marked for the BRIICs countries (Figure 3). This development is particularly detrimental for Pay-as-You-Go (PAYG) pension schemes as pension spending is financed by contributions of current working cohorts. It also affects health care spending, but to a lesser degree, with health technology developments playing a prominent role, but ageing has a strong effect on long-term care.

Consolidation needs calculated by Cournède et al. (2013) were updated with the latest vintage of pension and health care projections (Figure 4). They indicate that future public health care and pension spending pressures could be a considerable vulnerability source in many OECD countries. Policies to address spending pressures now are needed to avoid a considerable tax hike or benefit cut in the future. 
Figure 3. The old-age support ratio will halve in the OECD and by more in some BRIICS countries

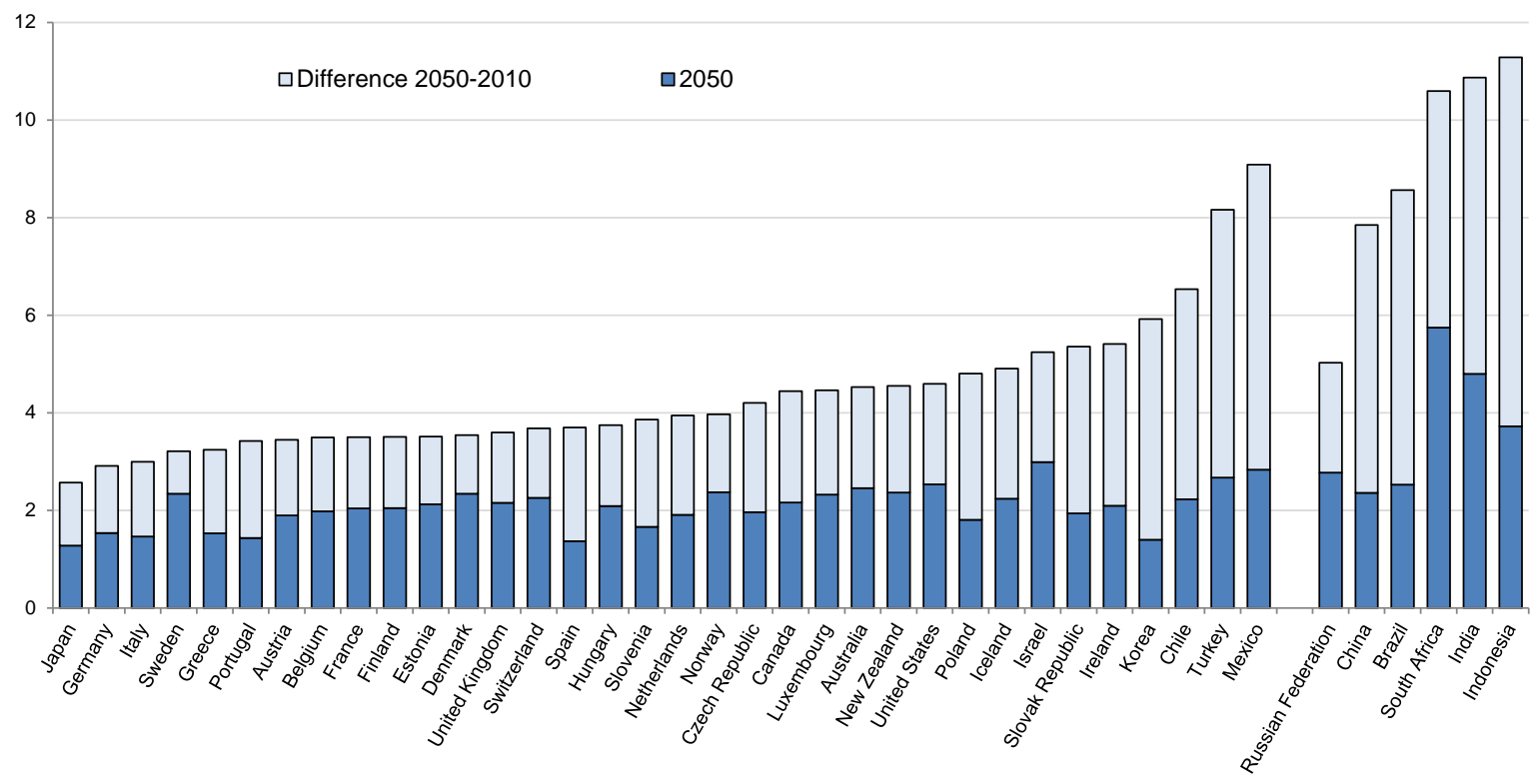

Source: OECD (2013), Pensions at a Glance 2013: Retirement-Income Systems in OECD and G20 Countries.

StatLink ants http://dx.doi.org/10.1787/888933080504

Figure 4. The impact of future health and pension spending on consolidation needs

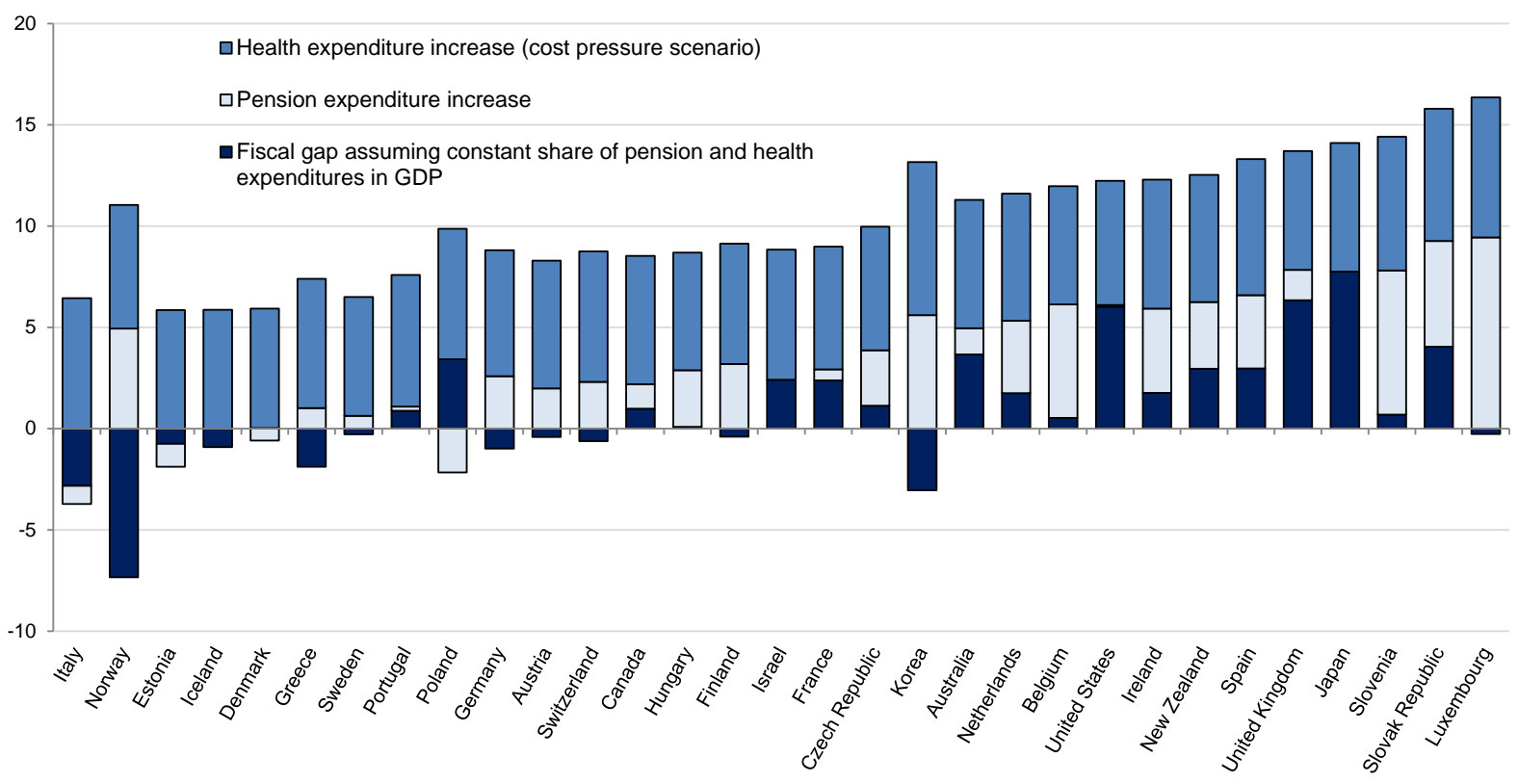

Note: The long-term consolidation needs (shown in dark blue) measure the difference between the underlying primary balance as a per cent of GDP that keeps gross general government debt stable at 60\% of GDP in 2060 and its baseline projection for the same year assuming unchanged GDP shares of public expenditure on pension and health.

Source: Cournède, B. et al. (2013), "How to Achieve Growth- and Equity-friendly Fiscal Consolidation? A Proposed Methodology for Instrument Choice with an Illustrative Application to OECD Countries", OECD Economics Department Working Papers, No. 1088; OECD (2013), Pensions at a Glance 2013: OECD and G20 Indicators; de la Maisonneuve and OliveiraMartins (2013), "A Projection Method for Public Health and Long-term Care Expenditures", OECD Economics Department Working Papers, No. 1048. 


\section{Ageing and pension systems}

\section{Impact of ageing on funded schemes}

The main impact of ageing on private funded pension systems results from the improvements in life expectancy and the uncertainty surrounding it (i.e. longevity risk). An increase in life expectancy lengthens the time people remain in retirement, which in turn increases the liabilities of definedbenefit (DB) pension plans and annuity providers (Antolín, 2007). In addition, the uncertainty about future longevity gains has affected the ability of $\mathrm{DB}$ pension funds to provide the level of retirement income participants were promised. In defined-contribution (DC) pension plans, individuals bear the risk and can counterbalance the effects of anticipated longer life spans by either saving more or working longer.

Population ageing will also affect funded private pensions through its impact on financial markets, in particular, on portfolio allocation and returns on investment. The impact of ageing on market returns is not straightforward and controversial. However, as far as pension fund managers can diversify their investments, they can cope with ageing by investing in countries with a younger population and stronger growth (at the cost of some exchange rate risk).

\section{Ageing and health care systems}

Increasing life expectancy explains little of the rising health care costs experienced in previous decades. Assuming that longevity gains will translate into additional years in good health (i.e. healthy ageing), a longer life is not among the main determinants of the projected rise in spending over the coming decades (de la Maisonneuve and Oliveira Martins, 2013).

Figure 5 shows that the health care spending-to-GDP ratio in 2060 is greatly affected by the assumption about healthy ageing. "Morbidity expansion" (which assumes that longevity gains do not translate into more years in good health) raises the projected health care spending-to-GDP ratio by 1.2 percentage points for the OECD countries on average and by 2.3 percentage points for the BRIICS countries. On the other hand, "morbidity compression" (which assumes that longevity gains lead to even more years spent in good health) leads to noticeably lower health care spending as a share of GDP. On average, morbidity compression could reduce the health care spending to GDP ratio by a 1 percentage point for the OECD countries and by more for the BRIICS countries. 
Figure 5. Health status in old age affects public health care spending Projections of public health care spending to GDP ratio, 2060

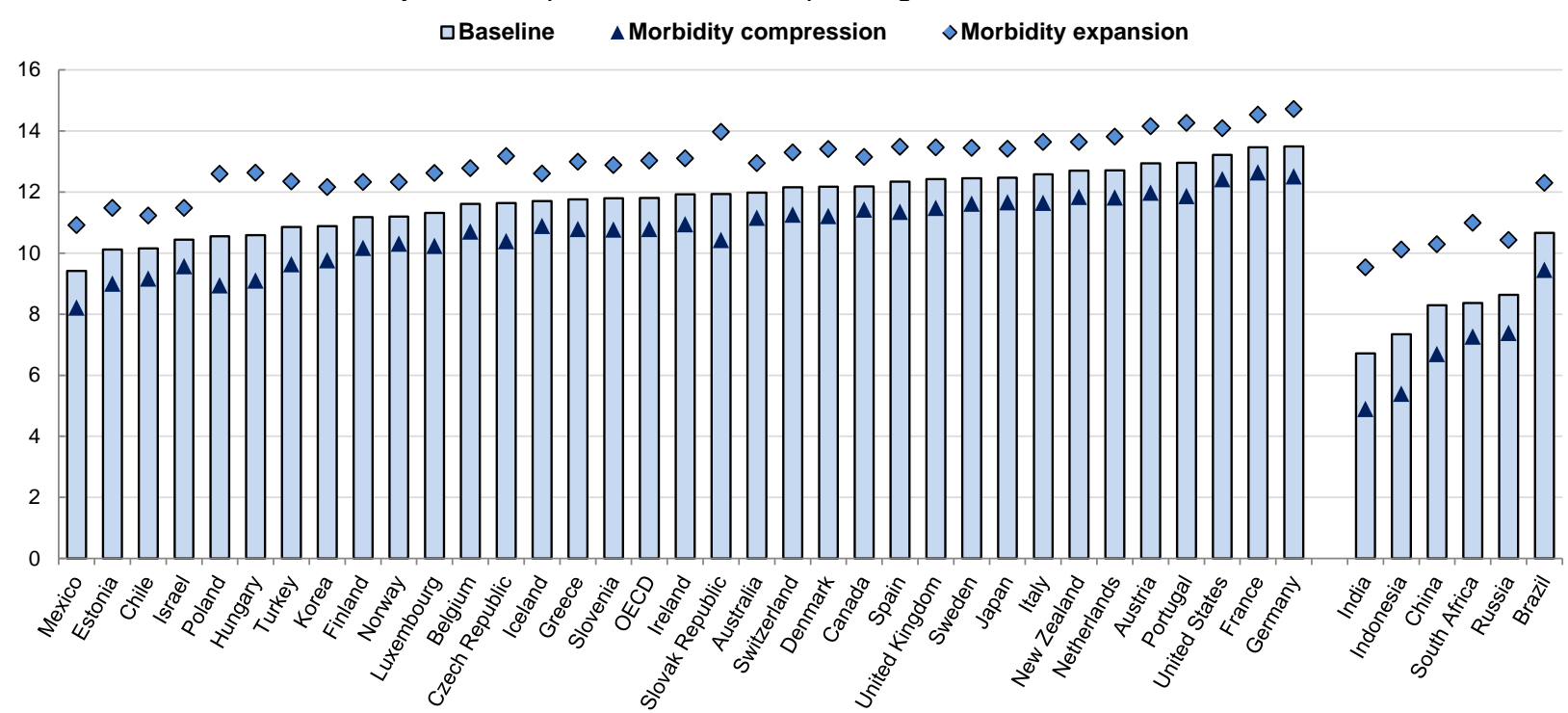

Note: In the baseline it is assumed that longevity gains translate into as many years spent in good health; "morbidity expansion" assumes that longevity gains do not translate into more years in good health; "morbidity compression" assumes that longevity gains lead to more years spent in good health.

Source: OECD calculations; de la Maisonneuve and Oliveira Martins (2013), "A Projection Method for Public Health and Long-term Care Expenditures", OECD Economics Department Working Papers, No. 1048.

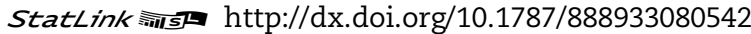

\section{Ageing and unemployment insurance schemes}

The recent labour market performance of older individuals has been good. The employment rate of older individuals increased, continuing a trend apparent before the crisis (OECD, 2013a). Earlier, older workers tended to withdraw from the labour market during downturns. Pension reforms, the phasing out of early retirement schemes and the tightening of eligibility criteria for other social transfer programmes that operated as de facto early retirement schemes have contributed to this outcome.

Unemployment rates among older workers are low relative to the average in almost all OECD countries. On the other hand, employment rates of older workers are still low in many countries, reflecting the tendency of older workers to leave the workforce rather than becoming unemployed. Reforms to increase employment among older workers and raising the retirement age may have the negative side-effect of increasing unemployment, since closing the remaining routes to early retirement and a better screening in disability schemes would increase participation rates of older workers, who may have difficulties finding a job. 


\section{Productivity growth trend and the sustainability of social systems}

\section{The outlook for health care spending under a lower productivity growth scenario}

Lower economy-wide productivity growth affects the public health spending-to-GDP ratio over the long run only marginally (Figure 6). A lower trend productivity growth rate of half percentage point was assumed and the productivity changes were translated into new GDP growth paths using the OECD Long-term Model. The effect of lower GDP on the health spending to GDP ratio is small, because the elasticity of health spending to GDP is relatively high, being 0.8 (de la Maisonneuve and Oliveira Martins, 2013).

Figure 6. The public health spending to GDP ratio is little affected by productivity changes

Health spending-to-GDP ratio (2060)

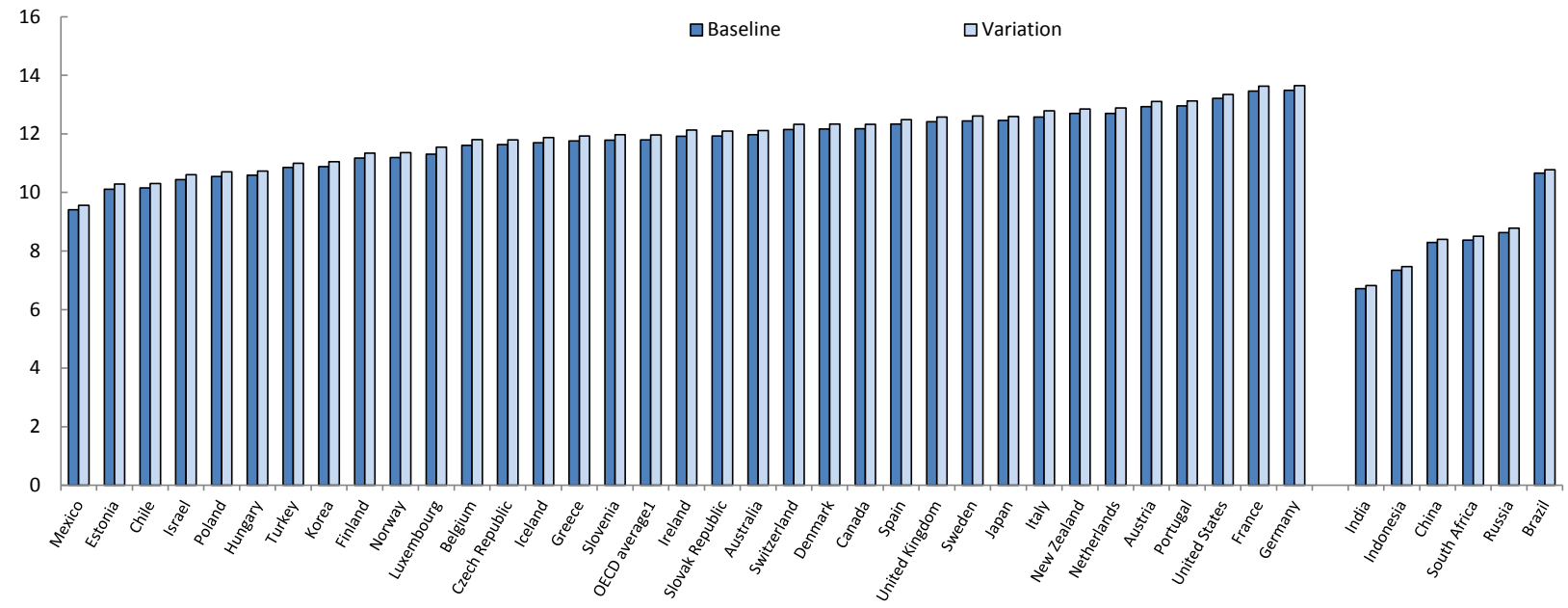

Note: The variant refers to a scenario with a $1 \%$ yearly productivity growth rate instead of $1.5 \%$ as in the OECD long-term baseline scenario. The elasticity of health spending to GDP is 0.8 .

Source: de la Maisonneuve and Oliveira-Martins (2013), "A Projection Method for Public Health and Long-term Care Expenditures", OECD Economics Department Working Papers, No. 1048; OECD (2013), OECD Economic Outlook No. 93: Statistics and Projections (database).

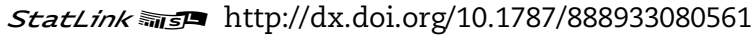

\section{Price and technology developments}

Price and health technology developments are an important determinant of health spending growth. De la Maisonneuve and Oliveira Martins (2013) show that for OECD countries they explain about $50 \%$ of the public health care spending variation from the 1990 s to the late 2000 s and $40 \%$ for the BRIICS countries. The rest is due to demographic and income effects.

Figure 7 shows that the impact of alternative price and technological developments to 2060 on the projected health care spending-to-GDP ratio could be large. The difference between the costpressure and cost-containment scenarios, as defined by de la Maisonneuve and Oliveira Martins (2013), approaches 4 percentage points. The cost-pressure scenario assumes that health care spending attributable to price, technology and health care policies and institutions will keep growing as in the past (1.7\% annually). The cost-containment scenario assumes a gradual decrease in the yearly growth of health care spending relating to price, technology and health care policies and institutions from $1.7 \%$ to zero in 2060. 
Figure 7.Price and technological developments affect the public health spending-to-GDP ratio

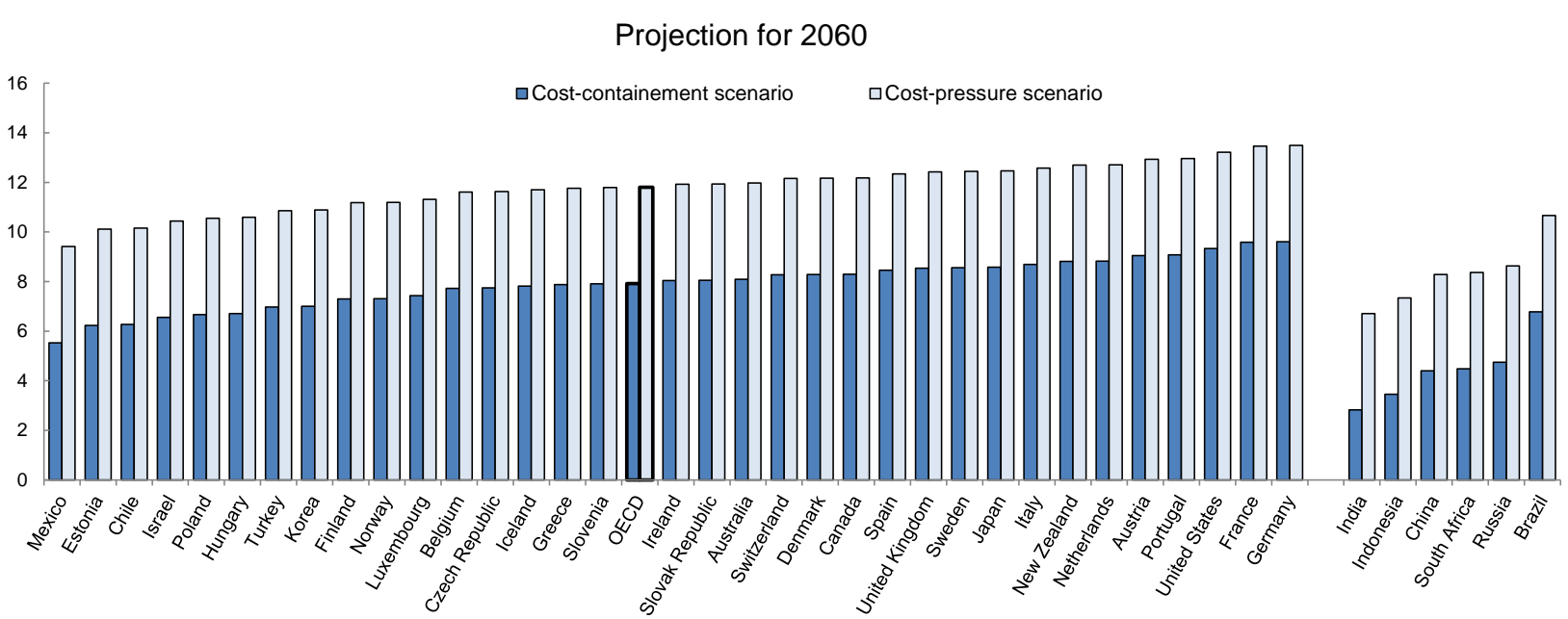

Note: The cost-pressure scenario is based on the assumption that the health care spending attributable to price, technology and health are policies and institutions will keep growing as in the past (1.7\% annually). The cost-containment scenario assumes a gradual decrease in the yearly growth of health spending relating to price, technology and health care policies and institutions from $1.7 \%$ to zero in 2060 .

Source: de la Maisonneuve and Oliveira Martins (2013). "A Projection Method for Public Health and Long-term Care Expenditures", OECD Economics Department Working Papers, No. 1048.

StatLink त्ञाs http://dx.doi.org/10.1787/888933080580

\section{Migration dynamics and social institutions}

\section{The effects of migration on health systems}

At the end of the 2000s, foreign-born people accounted for around $9 \%$ of the total population in OECD countries (OECD, 2012a). Despite a recent drop in migratory flows related to the economic crisis, which was especially sharp in the countries hardest hit during the recent crisis, the number of foreign-born people living in OECD countries increased by a third over the 2000s. The rise was especially marked in Spain, which experienced a three-fold increase and in Ireland and Iceland, where the share of the foreign-born people almost doubled.

How migration flows affect the health care sector depends on the health care needs of the immigrants and whether they have access to the same medical services as the native population. As recently arrived immigrants tend to be younger than the native-born population, countries with a recent wave of immigration are likely to experience a "healthy migrant effect" and immigrants are likely to weigh less than natives on the health care system. However, other factors, such as the level of education and income also determine the health care needs of immigrants, making the overall effect of immigration on health care expenditure difficult to pin down (OECD, 2012a).

On average, a larger share of foreign-born people report being in good health compared with natives (Figure 8). However, in Estonia, the Czech Republic and Slovenia the opposite is the case. Adjusting responses for age, educational and income characteristics results in lower differences in most countries. Notable exceptions are Norway, where the gap with the natives increases - most probably because of the large share of humanitarian immigrants - and to a lesser extent Australia, Canada, Sweden, Switzerland and the United States. Natives report more frequently chronic health conditions and health related limitations (i.e. disabilities). Overall, the cross-country correlation of the gaps between native and foreign-born people (both adjusted and unadjusted for age, education and income characteristics) along these three dimensions is high (above 0.6). This suggests that countries where immigrants report being in good health also report lower frequencies of disabilities and chronic conditions. 
Figure 8. Health of the foreign-born and native populations

Percentage of foreign-born and native adults reporting to be in good health, 2009

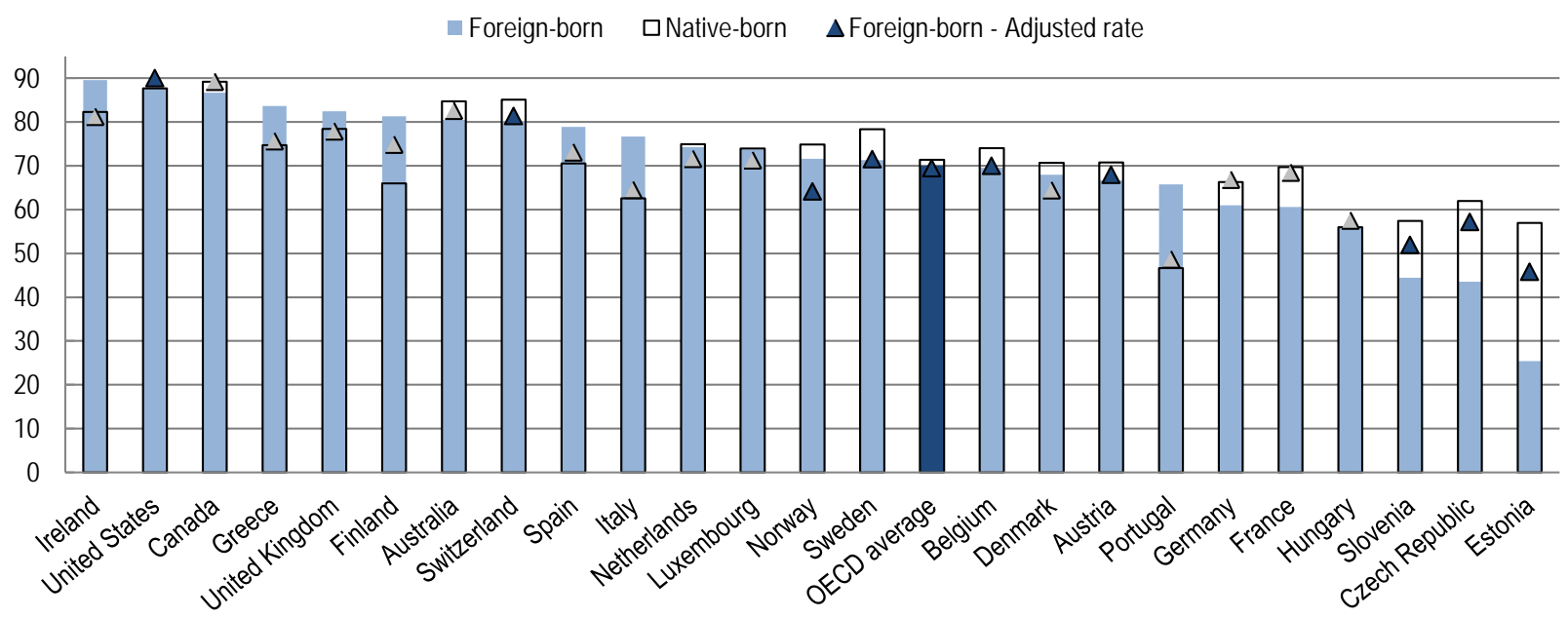

Note: The dark triangles show the foreign-born shares adjusted for age, education and income levels; grey triangles indicate differences not statistically significant at $5 \%$ level.

Source: OECD (2012), Settling In: OECD Indicators of Immigrant Integration 2012.

StatLink : inls http://dx.doi.org/10.1787/888933080599

As regards service adequacy, immigrants may not have the same access to health care services as natives for various reasons. Lower income may be one of these, but legislation can also prevent immigrants from having the same access to health care services as natives. Also, migrant workers retiring in a different country (often the origin country) from where they have worked can face limited or no access to health care services as access can be conditional on having contributed to the pension system of the country of residence. A study by the World Bank estimated that less than $25 \%$ of migrants work in host countries having bilateral agreements with the origin country, which guarantees access to health care services (Holzmann et al., 2005).

Immigrants in OECD countries do not seem to enjoy the same level of health care services as the natives. On average, across the OECD countries for which data are available, $7.1 \%$ of immigrants reported having experienced unmet medical needs over the $2009-10$ period, against $5.6 \%$ for the native population (Figure 9). Differences in the prevalence of unmet needs between the foreign-born and native populations are significant for about half of the countries. In all these countries, the foreignborn are more likely to have unmet needs than the natives. 
Figure 9. Unmet medical needs among foreign-born and native people

2009-10

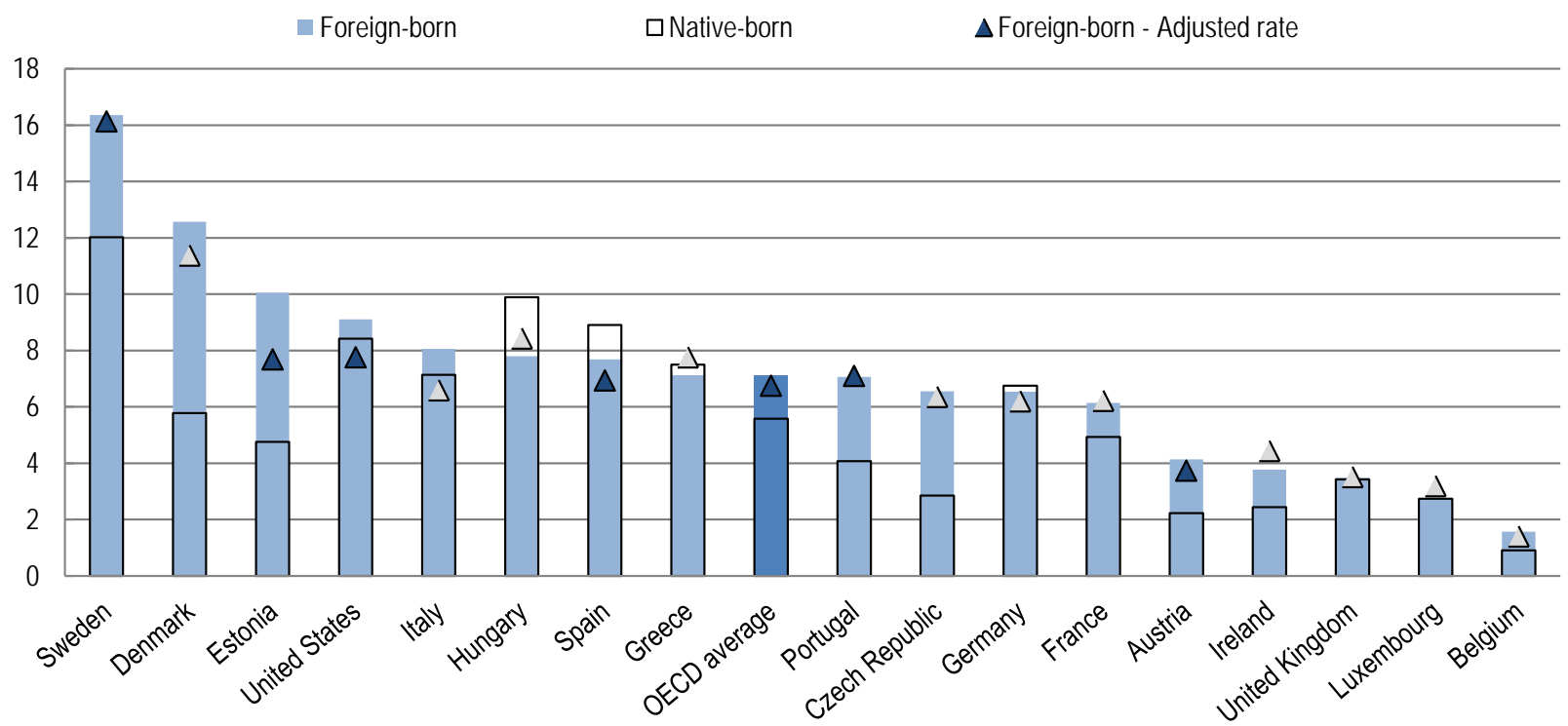

Note: The triangles show the foreign-born shares adjusted for age, education and income levels; grey diamonds indicate differences not statistically significant at $5 \%$ level.

Source: OECD (2012), Settling In: OECD Indicators of Immigrant Integration 2012.

StatLink :-ins http://dx.doi.org/10.1787/888933080618

\section{Migration, employment and unemployment insurance}

In 2012, the unemployment rate of immigrants in OECD countries was on average considerably above that of natives (Figure 10). Immigrants also tend to be more vulnerable to shocks, with a stronger increase in unemployment during the recent crisis than among natives. The immigrant unemployment rate is highest in those countries which were the hardest hit by the crisis. These countries have also cut back on public funds devoted to integration policies. Measures to integrate immigrants into labour markets in the destination country, as well as language, culture and skills play a role in shaping the labour market performance of immigrants. The propensity to be unemployed varies considerably across different immigrant groups. Mexicans in the United States have today the lowest employment rates among the foreign-born, partly as a result of their strong presence in construction and manufacturing sectors and their over-representation among the low-skilled. Also migrants from North Africa in Europe have experienced sharp employment losses. At $26.6 \%$, their unemployment rate reached a record high in 2012. 
Figure 10. Unemployment rates are often higher among immigrants than natives

2012

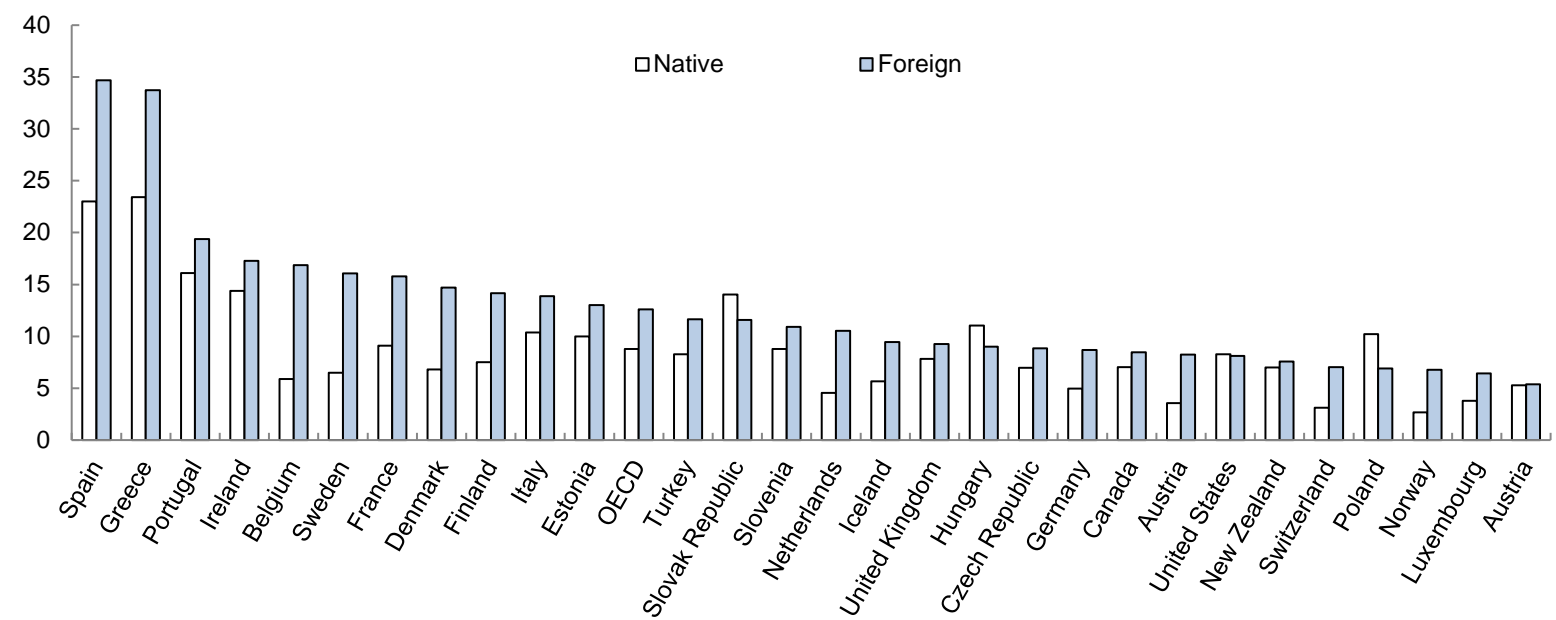

Note: Data refer to the working-age population (15-64).

Source: OECD (2013), International Migration Outlook 2013.

StatLink 需化 http://dx.doi.org/10.1787/888933080637

The population projections by the UN and Eurostat assume that past migration patterns will largely persist and strong flows of South-to-North migration are expected to continue. For the countries which have difficulties with integrating immigrants into the labour market, this does not augur well for future unemployment developments. On the other hand, migration projections based on a gravity model indicate that the expected rapid income convergence between OECD and emerging countries will lower the economic incentives for migration, and that the OECD may experience net emigration of economic migrants between 2010 and 2060 (OECD, 2014). While the United States could experience a net inflow of migrants, net emigration would be especially marked for the euro area, which would experience a substantial decline in the flow of low-skilled immigrants that have traditionally moved to the euro area, owing to relatively strong projected wage growth in their countries of origin. This would reduce unemployment in the countries that have difficulties in integrating immigrants.

\section{Vulnerability to short-run shocks}

\section{The impact of short-run shocks on the financing of social institutions}

Public social institutions mostly rely on taxation and social security contributions as sources of funding, which can be strongly affected by macroeconomic shocks. Taxation is mainly affected by GDP fluctuations and social insurance contributions by changes in the payroll. Box 2 reviews the different options to finance short-term shortfalls in social security revenues. No detailed internationally comparable data exist on the revenue sources of unemployment, health and pension schemes. Therefore, the volatility of social institutions' revenues is assessed looking at the volatility of total social security contributions and the part of general taxation that finances social institutions. 


\section{Box 2. Short-run shocks and the financing of social institutions}

The options for social institutions to adapt to revenue shocks depend on the type of the shock. Permanent shocks (such as ageing or lower productivity growth) require adjusting spending or raising additional revenue so as to ensure long-term sustainability. As social institutions, especially unemployment insurance, have an important automatic stabiliser role, bringing spending in line with revenues over the course of the cycle would be inefficient and reduce welfare. Besides limiting intertemporal risk sharing, changing spending to match revenues over a short period of time would result in benefits being closely linked to the economic cycle rather than actual social needs.

Revenue shocks around the trend (i.e. temporary shocks) can in principle be dealt with by two strategies. The first involves covering revenue shortfalls of social institutions during downturns by providing government transfers or by allowing social security schemes to borrow. This approach would ensure the smooth functioning of social institutions irrespective of macroeconomic conditions. The feasibility of this strategy depends on whether surpluses are accumulated in good times to offset the revenue shortfalls during downturns. In countries, which are prone to deficit bias the credibility of this approach may be limited. Strengthening fiscal institutions to reduce the deficit bias by defining clear fiscal rules and establishing independent institutions to monitor the application of such rules or act as official watchdogs could render this approach more credible (Wyplosz, 2012).

The other strategy involves the accumulation of reserve or buffer funds, which can be drawn upon in case of need. Many OECD countries have already pension reserve funds (Fall and Bloch, 2014), some have unemployment reserve funds, but health care buffer funds are rare (only Estonia has one). Buffer or reserve funds can have different functions (Fall and Ferrari, 2008). They help smoothing the fluctuations of social institutions' financing sources, thus ensuring benefits are available when most needed. For instance, during the recent crisis, Estonia has benefited from its health care reserve fund as it enabled the financing of health care expenditure despite the steepness of the Estonian downturn (Pisu, 2014). Buffer funds can also help finance expected temporary over-spending (compared to trend) resulting from the phasing in of structural reforms or a foreseeable structural change (for example, the retirement of the baby boom generation). Such funds could be wound down once structural reforms have been introduced and the impact of the shock has waned. Finally, buffer funds can provide additional permanent funding for social institutions; after the fund's build-up phase, its capital is preserved and its investment income contributes to the financing of social spending.

However, buffer and reserve funds are not a panacea. First, it can be difficult to distinguish between the structural and cyclical components of changes in target variables. Second, buffer funds can induce undue delays in structural reforms. Thirdly, the accumulation of buffer funds may involve intergenerational transfers, which may be difficult to justify in terms of equity. Finally, time inconsistency problems can arise as policy makers can be tempted to spend the resources of such funds during good times. Clear rules regulating the use of these funds coupled with independent institutions can mitigate time inconsistency problems relating to buffer funds (Wyplosz, 2012).

Even if buffer funds exist, central governments provide the ultimate back-stop for social institutions. The recent crisis has shown that a sound fiscal policy is most important in this respect as some OECD countries have been forced to introduce deep changes to their social protection systems during the crisis. In addition, there is very little scope to raise taxation in many European countries as tax pressure is already high.

Figure 11 ranks countries according to the volatility of the revenues of social security schemes, decomposing them into the volatility of social security contributions, transfers financed by taxation and a covariance term. Estonia and Finland show the most volatile revenue. On the other hand, Switzerland, Portugal, Germany and Australia have the most stable revenue. Countries with highly volatile social security revenues would benefit from having mechanisms in place (for instance, buffer funds) to deal with large revenue swings. 
Figure 11. Volatility index of social protection systems' revenues Contributions to overall volatility

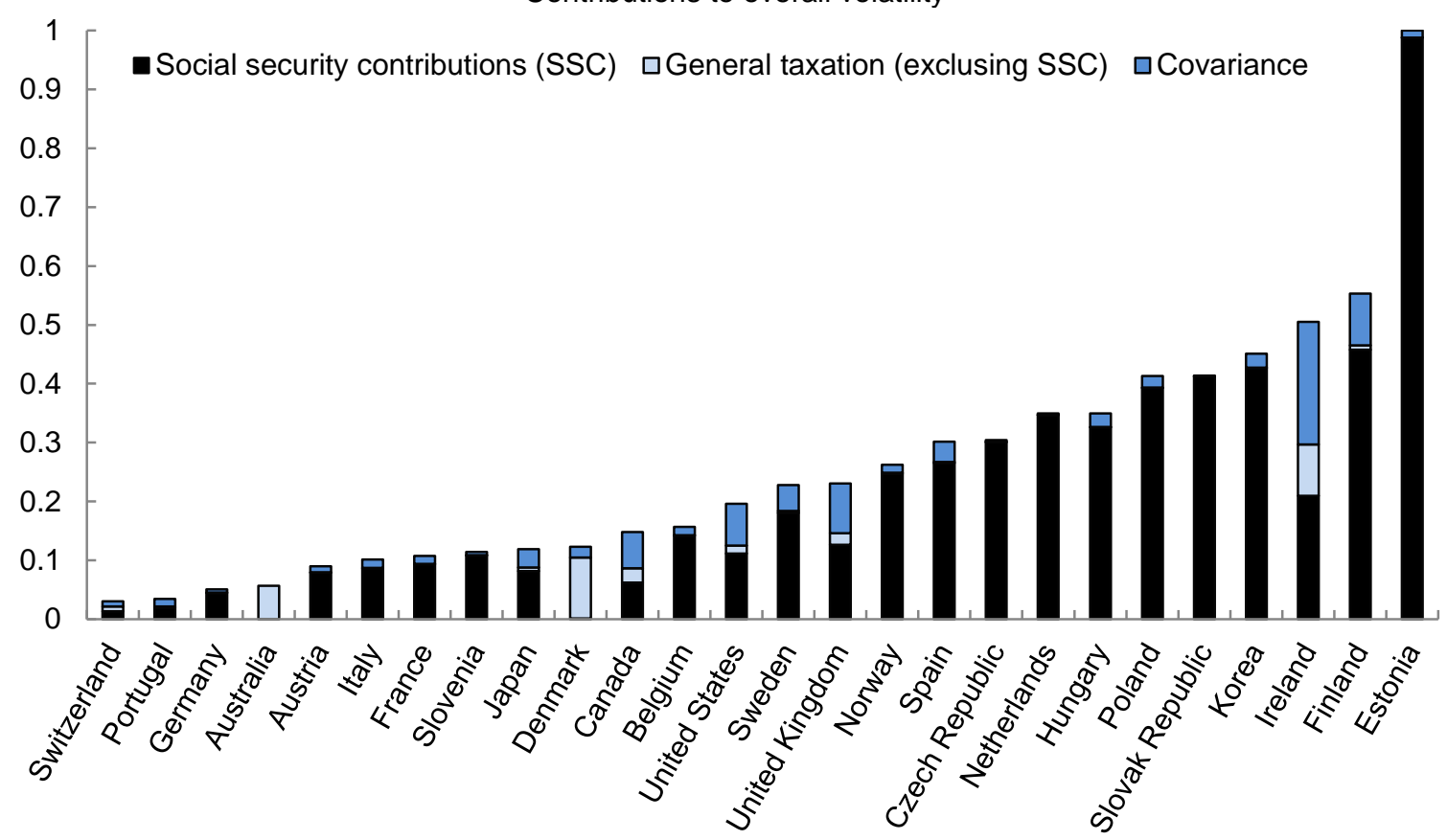

Note: The index is calculated as the coefficient of variation (i.e. ratio of the variance to the squared mean) of the deviation of real social security revenues (social security contributions plus transfers financed by general taxation) from a non-linear trend and is rescaled to lie between zero and one. To abstract from policy changes affecting tax rates and social security contributions, which would inflate revenue volatility, the index was calculated using constant implicit tax rates and therefore capture only the variation in the base, which is the wage bill for social security contribution and GDP for transfers. The contributions to the total reflect the volatility of the components and the share of the components in total revenue. Shares are kept constant and are based on 2006-10 averages. The coefficient of variation is decomposed into three components: the variability of social security contributions, of transfers and a covariance term capturing the co-movement of the two components. The estimation period differs across the countries. The whole time span for which data are available is used.

Source: OECD (2013), OECD Economic Outlook: Statistics and Projections (database), accessed October 2013.

StatLink त्ञाज http://dx.doi.org/10.1787/888933080656

The financing of social institutions also raises long-term macroeconomic efficiency issues, which may eventually affect the sustainability and adequacy of services. There is wide agreement that social security contributions are generally less efficient than some other government revenue sources, such as VAT, as the former distort labour markets (OECD, 2011a). ${ }^{1}$ For this reason, some countries have shifted - or consider doing so - part of the financing of public social institutions from social security contributions to other revenue sources. Australia and New Zealand are the only OECD countries that do not impose social security contributions and finance their entire social protection system through taxes. Relying more on general taxation rather than social insurance contributions would be advantageous for BRIICS countries as well, given widespread labour market informality.

Replacing social security contributions with VAT as a way of financing social institutions would involve large VAT rate increases. Figure 12 provides an approximate gauge of the effective VAT rate hikes that would be needed to offset the loss of revenues due to abolishing employer and employee social security contributions. The increase in effective VAT rates would be extremely steep (more than 20 percentage points) in countries with high social security contributions rates. However, even in countries that rely little on social security contributions, compared with other funding sources, effective VAT rates would need to rise by several percentage points. As regards the United States,

1.

However, VAT at high levels can have negative macroeconomic side effects. 
which has no VAT, imposing a VAT of about $7 \%$ would be enough to make up for the loss of social security contributions.

Figure 12. Hike in effective VAT rate needed to replace social security contributions

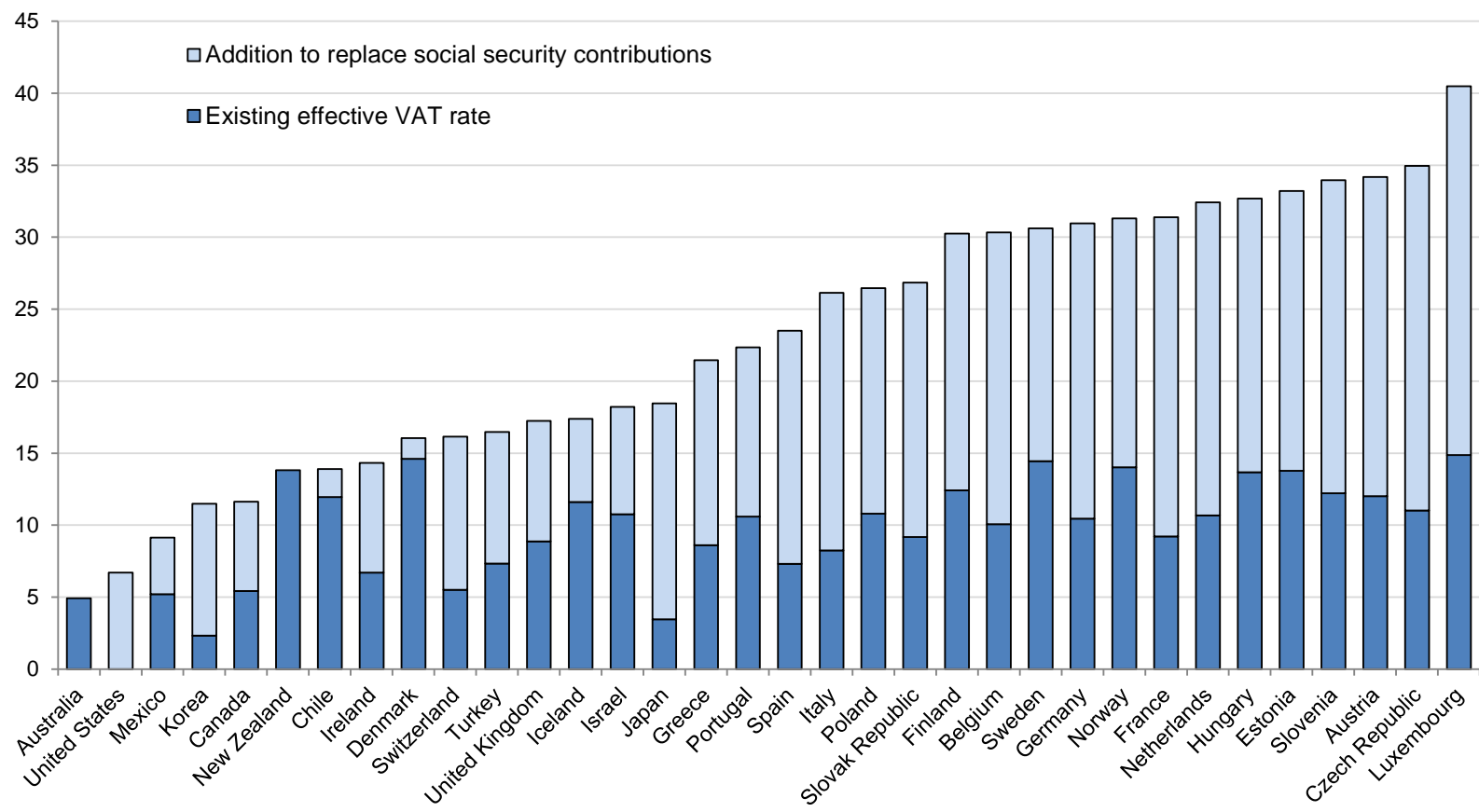

Note: The calculation is based on average 2010-12 data. Effective VAT tax rates are calculated as VAT revenue divided by private consumption net of VAT revenue. The effective tax rate compensating for the loss of social security contributions is calculated as VAT revenue plus social security contributions divided by private consumption net of VAT revenue. For Australia and New Zealand, no social security revenues are collected.

Source: OECD (2014), OECD Tax Statistics (database), accessed January 2014; OECD (2012), Consumption Tax Trends 2012: VAT/GST and Excise Rates, Trends and Administration Issues.

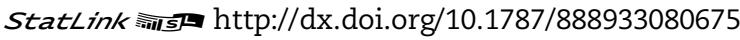

Private social institutions (i.e. private insurance) could play a more important role so as to relieve public budgets in the future, especially for health care and pensions. Different ways exist to further the development of private insurance: tax incentives and compulsory or quasi-compulsory enrolment. ${ }^{2}$ Non-targeted tax incentives have been criticised on cost (e.g. Yoo and De Serres, 2004; Martin and Whitehouse, 2008; Tapay and Colombo, 2004) and equity grounds (e.g. Toder et al., 2009; Antolín et al., 2004). However, tax incentives could play a useful role, if they were targeted at low income people. Mandatory private insurance schemes (such as in Switzerland for health care) or quasi-mandatory schemes (such as the KiwiSaver retirement accounts in New Zealand) are effective ways of promoting private insurance-based social institutions. Accompanied by subsidies for the less well-off and appropriate regulation (to counter asymmetric information and moral hazard), they could have the benefits of enhancing competition and driving down costs, providing more choice to consumers, while ensuring access to services for the less well off.

\section{Macroeconomic shocks and social spending}

The recent crisis caused a sharp increase in public social spending, both as a share of GDP (Figure 13) and in real terms. In Figure 13, in the countries in the upper-left panel, which saw a decline in GDP, social spending was counter-cyclical playing their automatic stabiliser role. Social spending increased in hard-hit countries, such as Spain, Portugal and Finland. Strikingly, the rise in social

2. Quasi compulsory are those schemes in which enrolment is automatic but participants can opt out. 
spending tended to be even higher in countries with relatively strong GDP growth (upper-right panel). Only Greece and Hungary could not maintain counter-cyclical social spending given the severe downturn and heavy fiscal retrenchment.

Figure 13. Social spending during the crisis

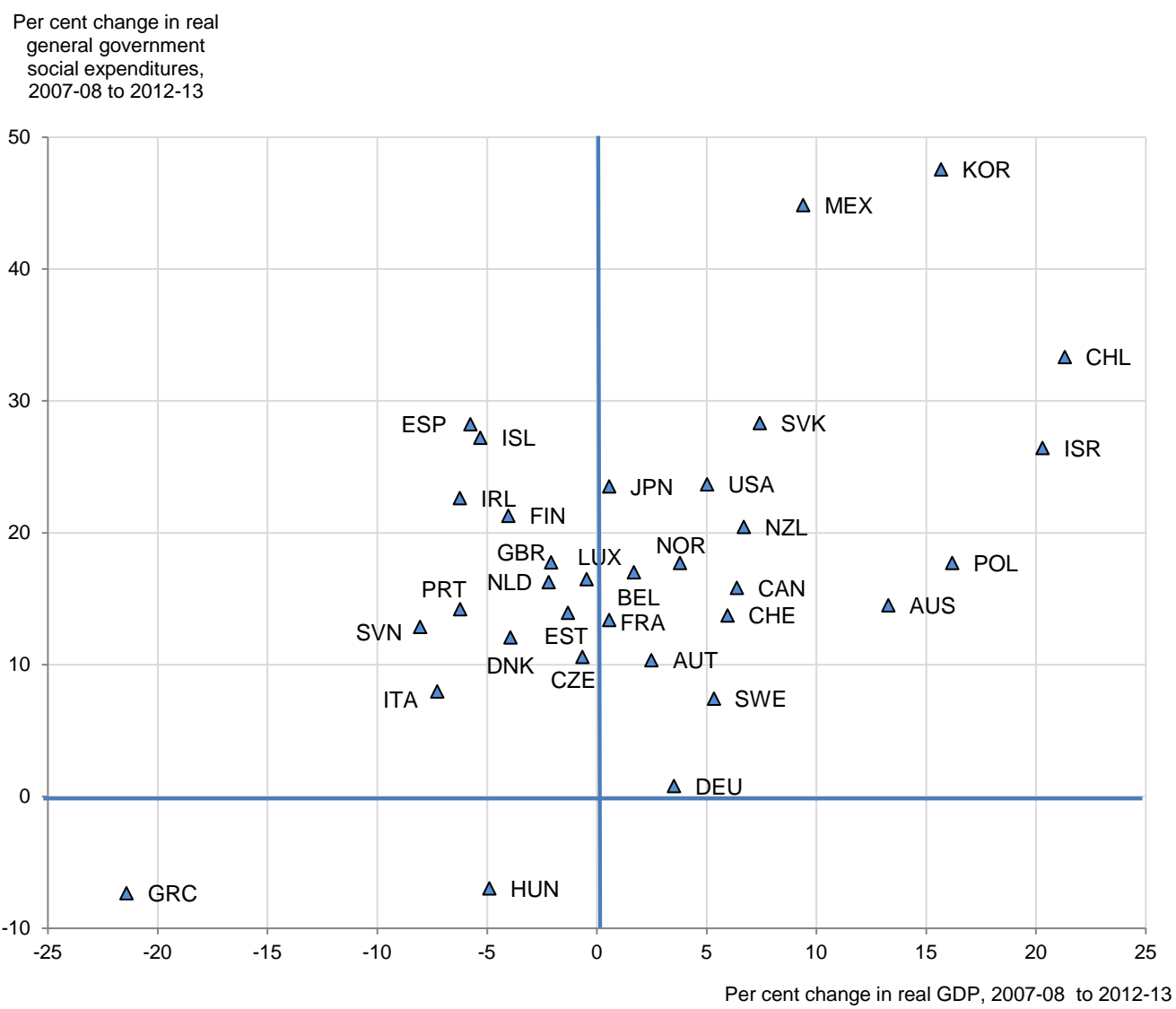

Note: Social spending is general government social security cash spending, thus not only including spending on unemployment health care and pensions, but also other items, such as family, housing or invalidity benefits. Detailed data on the various spending items are for some countries only available until 2009 and would thus cover only the beginning of the crisis. Unemployment, health care and pension spending are the bulk of social spending in most countries (Appendix Table 1).

Source: OECD (2013), OECD Economic Outlook No. 94: Statistics and Projections (database).

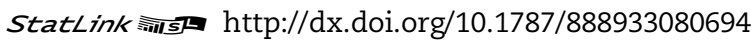

Social spending is affected by macroeconomic fluctuations, but there are marked differences across the schemes. Health care and, especially, unemployment insurance spending are correlated with cyclical variables, unlike pension spending. A rise in the unemployment rate has a negative effect on private health care spending (income effect) and a positive impact on unemployment insurance outlays. On the other hand, pension expenditure was mainly affected by long-run trends (the population over 65 and the female labour force participation rate) (Fall et al., 2014).

\section{Unemployment insurance and macroeconomic shocks}

As a prominent automatic stabiliser and risk-sharing tool, unemployment insurance is a counter-cyclical and volatile spending item by design. During the recent crisis unemployment insurance and active labour market policies expenditure increased in most OECD countries (Figure 14). In 10 countries, spending more than doubled from 2007 to 
2009-10. In some countries spending rose considerably more than the number of unemployed, reflecting high numbers of new entrants to unemployment insurance, an extension of duration, less stringent eligibility criteria, more generous benefits and increased ALMP spending, while in others the increase was considerably smaller, mainly because of reduced coverage, pointing to possible adequacy problems.

Figure 14. Unemployment and ALMP spending before and during the initial phase of the crisis

Average annual per cent changes, based on per capita spending in 2000 prices

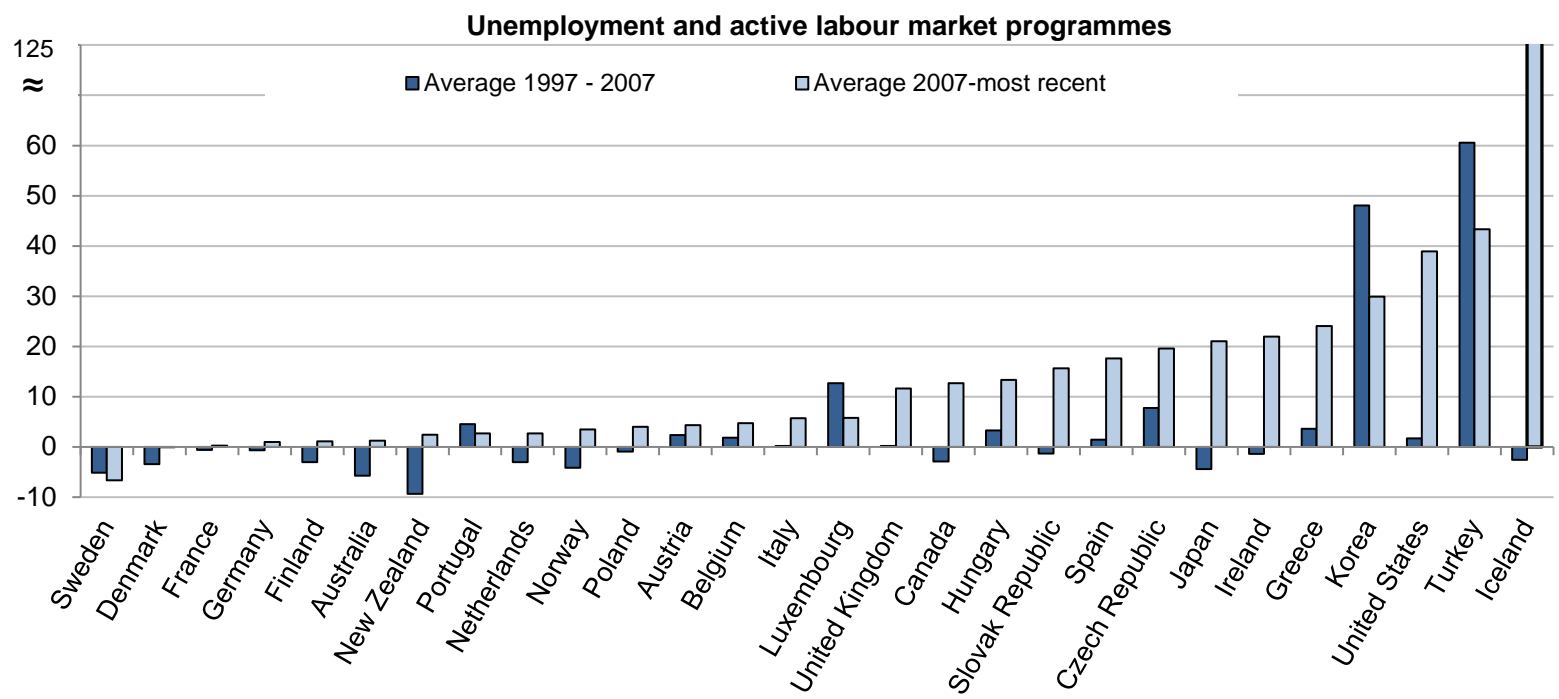

Note: Most recent data refer to 2010 for Australia, Germany, Ireland, Korea, Mexico, New Zealand and the United States. For all other countries shown, most recent data refer to 2009. Data are not available for Chile, Estonia, Israel, Slovenia and Turkey. Data are not shown for Switzerland, where the most recent data available refer to 2008.

Source: OECD Social Expenditure Statistics (database), accessed September 2013.

StatLink त्ञाI http://dx.doi.org/10.1787/888933080713

The vulnerability of unemployment insurance schemes to adverse macroeconomic shocks depends on how they translate into unemployment fluctuations and whether they affect structural unemployment via hysteresis effects. The structural unemployment rate has drifted up between the 1960s and 1990s in the OECD on average. It was then stable during the 2000s, but has drifted up again during the recent crisis (Figure 15, Panel A). A rise in structural unemployment puts upward pressure on unemployment insurance spending.

Unemployment volatility is an important aspect of the vulnerability of unemployment insurance schemes to macroeconomic shocks. Estonia, Ireland and Spain are the countries with the highest volatility of the unemployment rate around the mean (Figure 15, Panel B). The variability of expenditure, however, depends not only on unemployment fluctuations, but also how they translate into higher expenditure, which can be captured by the elasticity of unemployment spending with respect to the number of unemployed (Figure 15, Panel C). 


\section{Figure 15. Unemployment, volatility and expenditure response}

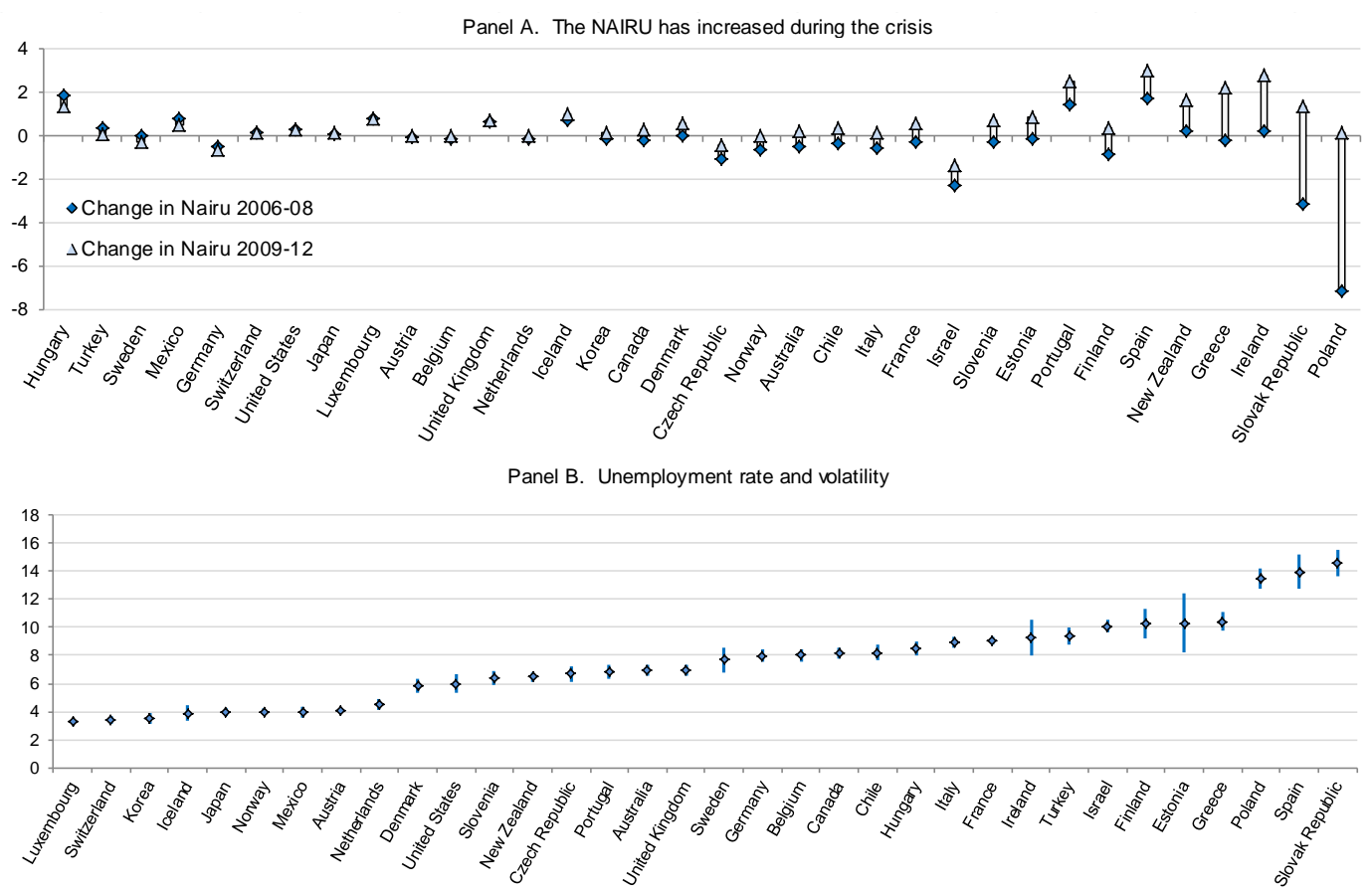

Panel C. Unemployment insurance expenditure elasticity to unemployment

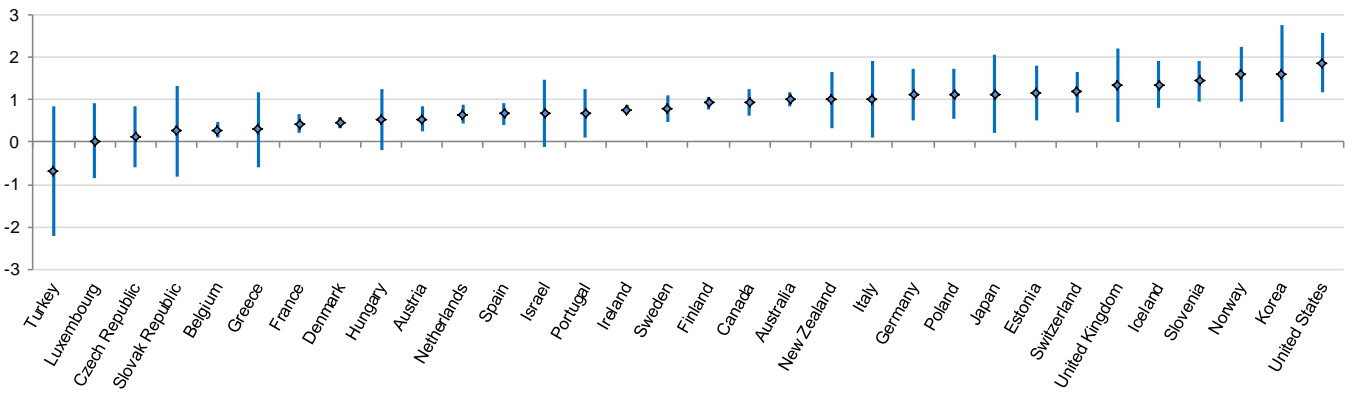

Panel D. Spending assymetries over the cycle exist in some countries

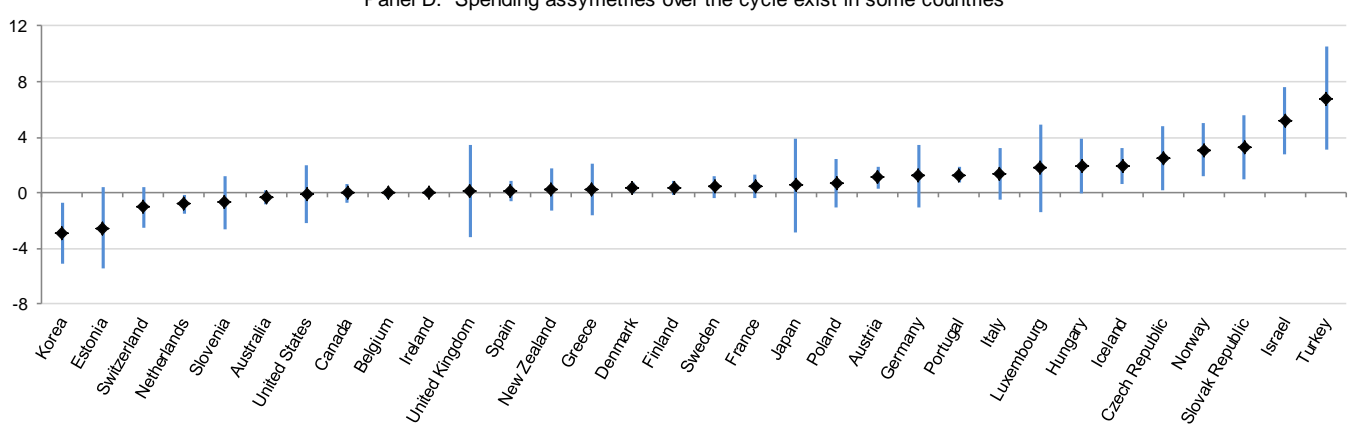

Note: Panel B shows the average unemployment rate from 1990-12 and 95\% confidence intervals around the averages. Panel $\mathrm{C}$ shows the expenditure elasticity of unemployment insurance with respect to unemployment, calculated with a simple bivariate OLS regression along with a $90 \%$ confidence interval of the regression coefficient. Panel D shows the difference of the elasticity of unemployment insurance expenditure to rising unemployment and declining unemployment with a $90 \%$ confidence interval. The sample period is 1990 to 2012 in panel B, C and D. Regressions on historical data do not necessarily reflect current challenges for all countries.

Source: OECD (2013), OECD Economic Outlook No. 93: Statistics and Projections (database); OECD Social Expenditure Statistics (database), accessed September 2013; OECD calculations. 
The very existence of volatility can contribute to undermine the sustainability of the scheme, if spending increases more in bad times than it is reduced in good times, as it does in some countries (Figure 15, Panel D). On average in the OECD, a 1\% increase in the unemployment rate since 1990 has led to a $1 \%$ increase in unemployment insurance expenditure, but a $1 \%$ drop in unemployment has only led to a $0.5 \%$ reduction in expenditure. The asymmetry may also reflect pro-cyclical generosity in unemployment benefits. Cross-country differences are large, with some countries (Turkey, Israel, the Slovak Republic, Norway, the Czech Republic, Iceland, Portugal and Austria) showing large and statistically significant asymmetries.

Such "stickiness" of expenditure leads to unemployment insurance increasing more than the wage base, which is unsustainable in the long run (Box 3). Increasing benefits during a crisis and then maintaining a higher level can make good sense if benefit generosity or coverage are too low. On the other hand, increasing benefits might reduce work incentives and turn the cyclical increase in unemployment into a structural increase (hysteresis). This can deepen and prolong a downturn and lead to structural weaknesses if comparable measures to improve incentives and public finances in good times are held back due to institutional and political factors.

\section{Box 3. GDP shocks can lead to an upward creep in unemployment insurance spending}

A way of looking at the long-term financial soundness of unemployment insurance schemes is whether financing can be expected to keep pace with spending in the face of shocks. In most countries, the financing of unemployment insurance schemes is based on social security contributions levied on wages. For a given contribution rate, the vulnerability of a scheme increases when unemployment insurance spending shows a tendency to increase as a share of the total wage bill.

This type of vulnerability can be captured by stochastic simulations of the ratio of unemployment insurance spending to the total payroll. The unemployment insurance spending to the wage bill ratio can be projected to 2050 using stochastic simulations (Appendix in Pareliussen, 2014). These past shocks are used in country-specific equations simulating the impact of such shocks on the ratio of unemployment insurance expenditure to the total wage bill. It is expected, that the greater GDP volatility is, the larger will be the dispersion of the unemployment benefit-to-payroll ratio. In addition, the skewness of the distribution of the unemployment spending-to-wage bill ratio is increasing with the degree of asymmetry of the GDP shock distribution and the difference in the response of the unemployment spending-to-wage bill ratio to positive and negative GDP shocks.

Some countries were more exposed to GDP shocks as illustrated by the differences in the sensitivity of unemployment spending and revenues to GDP shocks. However, whether future shocks will follow the patterns of the past is an open question and expenditure responses to shocks may change as fundamentals and institutions change. Figure 16 shows the average unemployment benefitto-payroll ratio in 2007-10, the projected values in 2050 and the $90 \%$ confidence interval under the assumption that GDP shocks are the same as in the past. Countries such as Ireland, Denmark and Portugal face a central estimate much above today's level, whereas others (Finland, Spain and Italy) display high risks as their spending ratio distribution is heavily skewed towards the right. Some countries display a combination of several unfortunate trends, as is the case for Finland and Hungary, with high current spending, a substantial tendency to drift upwards as revealed by past stickiness, and high upside risks to spending. 


\section{Box 3. GDP shocks can lead to an upward creep in unemployment insurance spending (cont.)}

Figure 16. Vulnerability of unemployment insurance schemes to GDP shocks

Projected unemployment insurance expenditure as a ratio of the wage bill (2050)

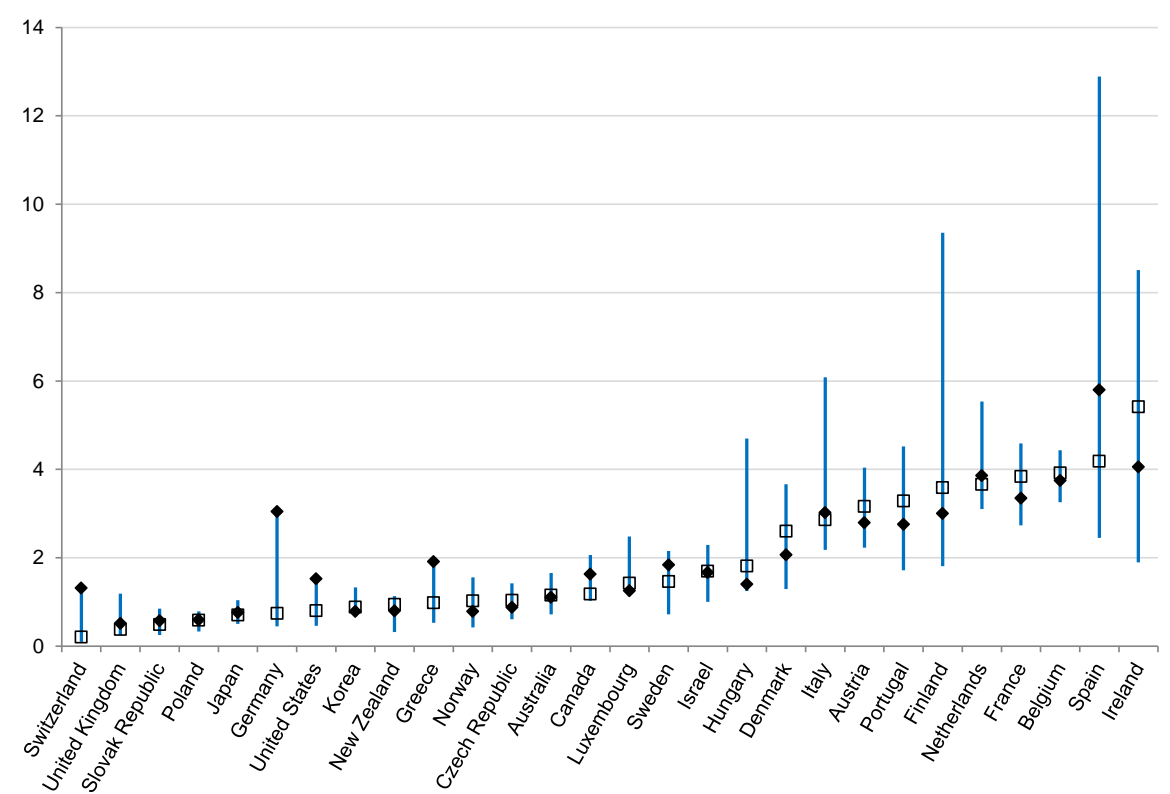

Note: The solid diamonds represent the 2007-10 average of the ratio of unemployment insurance spending to the wage bill; the squares represent the 2050 central projection (median); the lines represent the $90 \%$ confidence interval. The 2050 estimates and confidence intervals are based on country-specific equations of the ratio of unemployment insurance expenditure to the total wage bill on its lagged value and positive and negative output shocks. This model captures the asymmetric responses to positive and negative shocks. The methodology for extracting output shocks is described in Pareliussen, 2014.

Sources: OECD Social Expenditure Database; OECD (2013), OECD Economic Outlook No. 93: Statistics and Projections (database); OECD calculations.

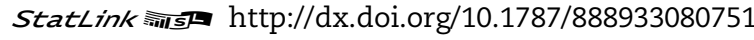

\section{Health care systems and GDP shocks}

Health care systems are also vulnerable to large GDP variations as health spending responds differently to positive and negative GDP changes. Figure 17 shows projected health care expenditure as a percentage of GDP by de la Maisonneuve and Oliveira Martins (2013) and the $90 \%$ confidence bands associated with the cumulative effect of GDP shocks. There is evidence that the elasticity of health spending with respect to GDP is close to 0.8 when GDP rises and close to zero when it declines (Pisu, 2014). As a consequence, GDP shocks will have a cumulative effect over time, possibly leading to a higher health spending to GDP ratio than that based on trend GDP growth. The simulation of GDP shocks to 2060 suggests that health care systems are more vulnerable to GDP shocks in Portugal, Ireland, Estonia, Spain and Iceland because of the large GDP shocks these countries have experienced. Overall in the BRIICS, health care systems do not seem to be significantly more vulnerable to GDP shocks than OECD countries. On average, the impact of GDP shocks on future health spending is modest as GDP contributes little to explain health spending growth across countries (de la Maisonneuve and Oliveira Martins, 2013). 
Figure 17. The vulnerability of public health spending to GDP shocks is modest in most countries

Health care spending as \% of GDP

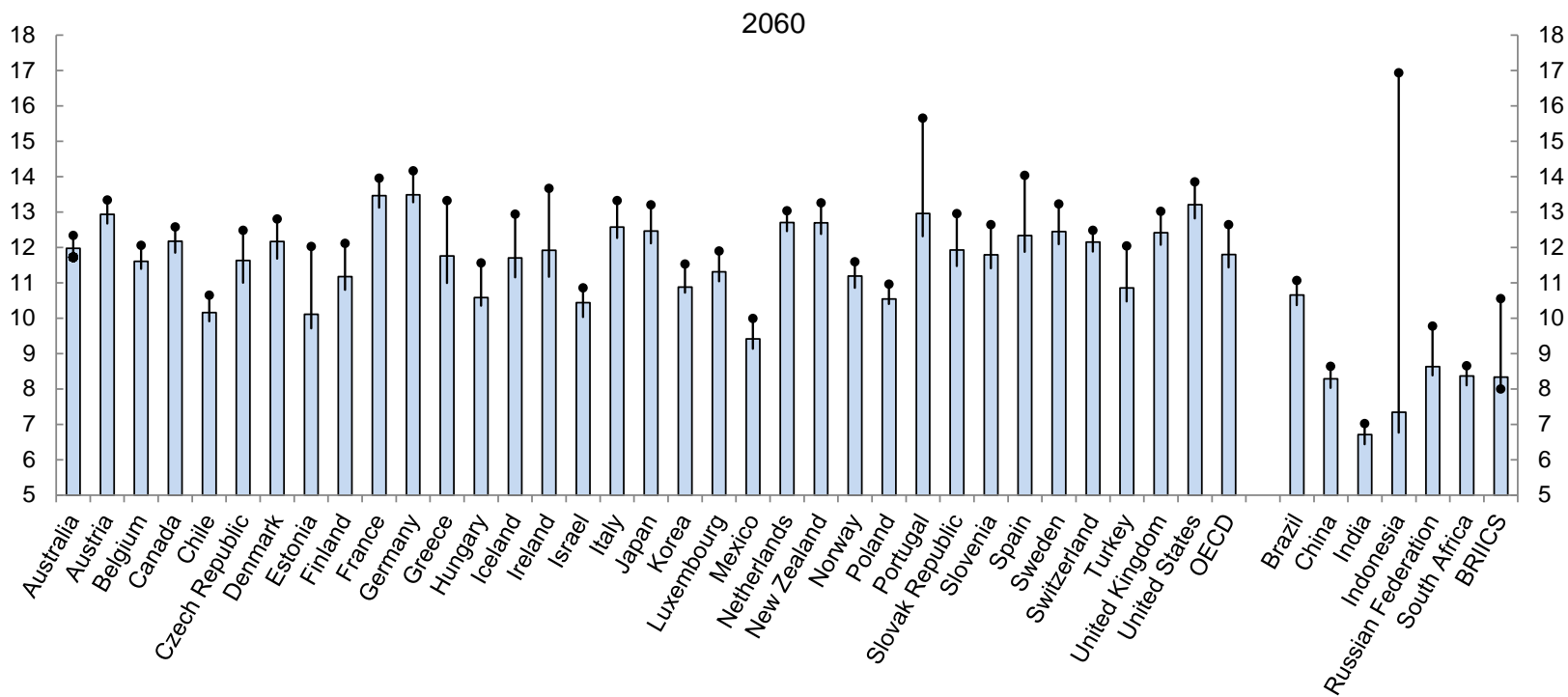

Note: The bars show the health spending to GDP ratio projections under the cost-pressure scenario of de la Maisonneuve and Oliveira Martins (2013). The top and bottom circles represent the 95th and 5th percentiles of the simulated health care spending distribution in 2060. They are obtained assuming an elasticity of health-care expenditure to GDP equal to 0.8, when real GDP rises and zero when GDP diminishes in line with the estimates provided in Pisu (2014).

Source: OECD (2013), OECD Economic Outlook No. 93: Statistics and Projections (database); and de la Maisonneuve and Oliveira Martins (2013), "A Projection Method for Public Health and Long-term Care Expenditures", OECD Economics Department Working Papers, No. 1048; OECD calculations.

StatLink 세프 http://dx.doi.org/10.1787/888933080770

Investment risks, interest rate variations, inflation and their effects on pension systems

Funded pension schemes are exposed to investment risks and changes in asset prices. The recent crisis illustrates the high uncertainty and risks surrounding investment in stocks (Figure 18). OECD (2009) estimates that pension funds lost 23\% of their value in 2008, worth about USD 5.4 trillion.

D'Addio et al. (2009) using historical data on returns on equities and bonds in major OECD economies over the past quarter century show a median annual real return of $7.3 \%$ on a portfolio equally split between equities and bonds (averaging across the countries studied). It might be expected that, over a very long period, the degree of uncertainty in investment returns is small, as a few bad years in the market are likely to be offset by boom years. However, they found the degree of uncertainty to be large, even for the relatively long investment horizons of pensions. In $10 \%$ of cases, an annual return of less than $5.5 \%$ was achieved, while in $10 \%$ of cases, it exceeded $9.0 \%$. Also, returns achieved by individuals on their pension fund assets are less than the market return due to administrative charges that can be large (OECD, 2013c), agency and governance effects. 
Figure 18. Average real net investment return of pension fund assets

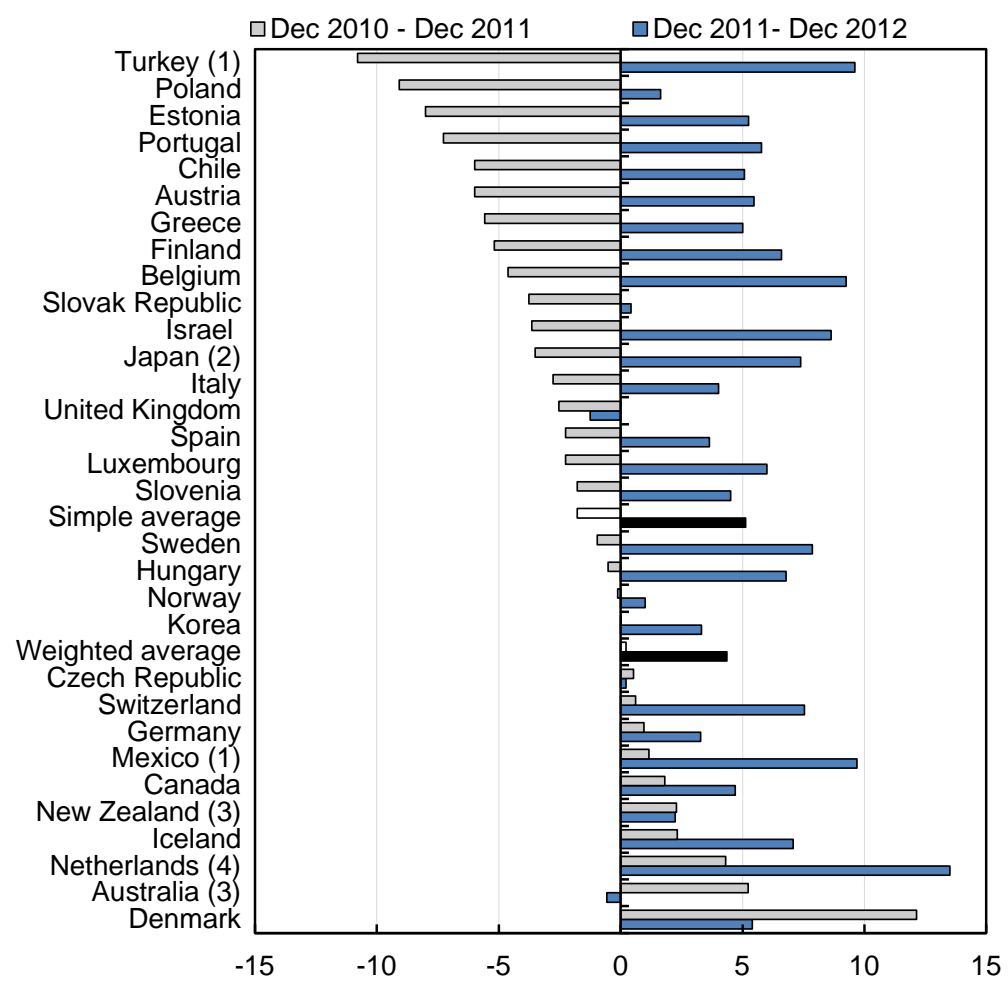

Note: Data have been calculated using a common formula for the average nominal net investment return (ratio between the net investment income at the end of the year and the average level of assets during the year). Average real net investment returns have been calculated using the nominal interest rate and the variation of the end-of-period consumer price index between 2010 and 2011, and 2011 and 2012 for all countries, except for Austria, Israel, Korea, and Sweden, for which values have been provided by the countries. The 2010-Q2, 2011-Q2 and 2012-Q2 consumer price index per year have been used for Australia and New Zealand. Averages are calculated over countries for which data for both 2011 and 2012 are available.

1. Data refer to personal pension plans only.

2. Source: Bank of Japan.

3. The average rates of return are calculated over the period June 2010-June 2011, and June 2011-June 2012

4. Data for 2012 are preliminary.

Source: OECD Pensions Statistics (database); OECD (2013), Pension Markets in Focus 2013.

StatLink הत्माs http://dx.doi.org/10.1787/888933080789

Inflation shocks affect both PAYG and funded schemes. In PAYG schemes, price indices are often the basis for the indexation and revaluation of pensions which play an important role in determining the level of pensions. First, they determine the level of the pension as they are used as the revaluation rate for past contributions or income to calculate the reference wage in defined-benefit schemes. Second, they determine the level of pensions during retirement. In many countries, pension indexation has been shifted from average nation-wide wage growth rate to inflation. Pensions are nowadays indexed to price developments in 13 OECD countries, a mix of wage and price weighting in six countries, wage or a fraction of the wage evolution in five countries and a mix of inflation and GDP growth in two countries.

As prices tend to grow at a slower pace than earnings, indexing pensions to price developments increases financial sustainability. However, in the long run and for future generations, there is a risk of creating an important income gap between workers and old retired people. This, in turn, may pose a sizeable risk to social safety nets for the elderly, regardless of whether they are financed by the pension system or other government entities. 
In funded schemes, inflation and interest rate risks are also related to pension payments. Funded DB schemes are exposed to inflation risk as far as they guarantee pension payments in real terms. ${ }^{3}$ If this is not the case, the pensioner can suffer from a large decline in the pension in real terms in the case of an inflation shock. The insufficient availability of appropriate asset types to hedge interest rate and inflation risks partly explain the limited availability of annuity products.

\section{Overcoming vulnerabilities of pension systems}

In most OECD countries, mandatory public pension schemes are pay-as-you-go (PAYG) definedbenefit (DB) schemes. In only four countries (Australia, Chile, Israel and Mexico), there is no public contributory mandatory scheme, but private mandatory defined-contribution (DC) schemes exist. In addition, there are many funded DC schemes in OECD countries. PAYG and funded schemes are exposed to various shocks in different ways.

Demographic shocks are a main source of vulnerability of pension systems. Demographic developments are unfavourable to the financial sustainability of pension systems in all OECD countries. Ageing is particularly detrimental for PAYG pension schemes as pension spending is financed by contributions of current workers. This is compounded by lasting effects of the recent crisis and slowing productivity growth.

Public pension spending is projected to increase up to 2050 in all OECD countries except in Estonia, Denmark and Poland. According to European Commission projections, with unchanged legislation, pension systems would be in deficit in fourteen EU-OECD countries in 2060 (Fall and Bloch, 2014).

A combination of different policy measures can ensure the sustainability of pension systems. For instance, many countries are phasing in increases in the retirement age to restore the financial health of pension schemes. More generally, adjusting key parameters automatically to cope with changes in structural variables can increase both the financial robustness of pension systems and the risk awareness of their participants. This section focuses first on the exposure of PAYG schemes to shocks and trend changes and on policies to cope with ageing. Then, it considers policies that can make funded schemes more resilient to assets price, investment and interest rate shocks.

\section{Vulnerability of PAYG pension schemes to shocks}

OECD-wide, public pension spending is expected to increase from 9\% of GDP in 2010 to $12 \%$ of GDP in 2050. Pension spending is expected to be above 15\% of GDP in 2050 in France, Greece, Italy, Austria, Belgium, Slovenia and Luxembourg (OECD, 2013b). However, countries are also exposed to productivity growth changes or negative migration developments (OECD, 2014) that can undermine the sustainability of PAYG pension schemes.

Two stylised PAYG models, a defined-benefit and a point scheme, have been developed to illustrate the transitional and permanent impacts of different types of shocks (Box 4). Fall (2014) provides more detail on the model parameters, the simulation assumptions and results.

3. For instance, in the Netherlands $93.5 \%$ of the employees in pension funds at the beginning of 2012 were covered by a defined-benefit scheme (OECD, 2013b). 


\section{Box 4. Key features of two stylised pension models and their reaction to shocks}

\section{The PAYG DB scheme}

- In the PAYG defined-benefit scheme, employees contribute to the financing of the scheme during their career. At retirement, the pension is calculated by applying a pension rate to the reference salary, which is the average career salary. The reference salary depends on the revaluation index used to up-rate past salaries at the retirement year, which is the growth rate of wages. During retirement, pensions are indexed to the inflation rate.

- At the scheme level, each year's contributions pay current pensions. The annual balance depends, on the financing side, on the size of the payroll and the contribution rate and, on the spending side, on the number of retirees and on the average pension. If pension spending exceeds total contributions the scheme is in deficit. The actuarial balance of the scheme is the discounted sum of the expected annual balances of the scheme over the projection period.

\section{The PAYG DC point scheme}

- The accumulated rights of an individual are calculated in terms of the number of points accumulated over the working life. The number of points acquired is determined by dividing contributions paid by the purchasing value of the point, which is determined as the price of one unit of differed life annuity. The pension at retirement is calculated by multiplying the number of points by the service (or selling) value of the point, which is the balancing value of the scheme. The service value of the point is identical for all insured individuals. It converts the points into monetary values at the retirement year and also during retirement. Thus, pension levels during retirement are revalued with respect to its development.

- The purchasing value of the point and the service value of the point are the two key parameters for the steering of the scheme. They are adjusted to ensure that the scheme remains in balance. Point prices depend on the projection of life expectancy by age cohort.

Both schemes are in steady state in the baseline scenario and balanced. In the baseline demographic scenario the mortality rate is constant. There is thus no ageing and the number of retirees is constant. Alternative scenarios show the effect of various shocks as deviations from the baseline.

Notional defined-contribution (NDC) schemes (as in Sweden and Italy) are not modelled, but their functioning is close to a point scheme with the difference that contributions are recorded in individual accounts. In particular, the internal rate of return on accumulated capital is set to guarantee the actuarial balance of the scheme. It has the same function as the adjustment mechanisms of the point scheme. In both cases, the determination of the adjustment mechanisms takes into account the evolution of life expectancy.

\section{The impact of a productivity shock}

The stylised model was used to simulate the impact of a productivity shock on a DB scheme. Under the assumption that productivity and real wages move in tandem over longer periods, the productivity shock is simulated as a permanent reduction in the growth rate of the real wage by 1 percentage point.

Due to the shock, the balance of the DB scheme moves gradually into deficit up to year $40(-17 \%$ of baseline revenues) and then it improves gradually to $-5 \%$ of baseline revenues in the long run (Table 1). As initial pensions are tied to wage developments, the average pension decreases considerably in the long run in comparison with the baseline average pension. Revenues go down by even more, as revenues depend on the wage bill, which is much larger than the pension bill. 


\section{Box 4. Key features of two stylised pension models and their reaction to shocks (cont.)}

The PAYG DC point scheme is balanced by definition. As the revenues of the scheme decrease, pension benefits shrink progressively leading to a reduction in the average pension by $50 \%$ compared with the baseline average pension. The service value of the scheme decreases in line with the revenues of the scheme. In the long run as the cohorts entering into retirement are affected by the productivity shock and therefore have accumulated less capital points, the decrease of the service value necessary to balance the scheme is lower than that the one in the medium term.

Table 1. Vulnerability of PAYG schemes to shocks Difference with respect to the baseline

\begin{tabular}{|c|c|c|c|c|}
\hline & $\begin{array}{c}\text { Year } 10 \\
\text { after the } \\
\text { shock }\end{array}$ & $\begin{array}{c}\text { Year } 30 \\
\text { after the } \\
\text { shock }\end{array}$ & $\begin{array}{l}\text { Year } 40 \\
\text { after the } \\
\text { shock }\end{array}$ & $\begin{array}{c}\text { Year } 70 \\
\text { after the } \\
\text { shock }\end{array}$ \\
\hline & \multicolumn{4}{|c|}{ Productivity shock } \\
\hline \multicolumn{5}{|l|}{ DB scheme } \\
\hline Difference in balance (in \% of baseline revenues) & -0 & -7 & -17 & -5 \\
\hline Difference in average pension (in \%) & -3 & -13 & -16 & -44 \\
\hline \multicolumn{5}{|l|}{ Point DC scheme } \\
\hline Difference in average pension (in \%) & -3 & -20 & -33 & -50 \\
\hline \multirow[t]{2}{*}{ Difference in point service value (in \% of baseline value) } & -2 & -17 & -30 & -22 \\
\hline & \multicolumn{4}{|c|}{ Migration shock } \\
\hline \multicolumn{5}{|l|}{ DB scheme } \\
\hline Difference in balance (in \% of baseline revenues) & -2 & -5 & -7 & 0 \\
\hline Difference in average pension (in \%) & 0 & 0 & 0 & -2 \\
\hline \multicolumn{5}{|l|}{ Point DC scheme } \\
\hline Difference in average pension (in \%) & -2 & -5 & -7 & -2 \\
\hline \multirow[t]{2}{*}{ Difference in point service value (in \% of baseline value) } & -2 & -4 & -6 & 0 \\
\hline & \multicolumn{4}{|c|}{ Ageing shock } \\
\hline \multicolumn{5}{|l|}{ DB scheme } \\
\hline Difference in balance (in \% of baseline revenues) & -7 & -23 & -26 & -29 \\
\hline Difference in average replacement rate (in \% points) & -4 & -3 & -4 & -5 \\
\hline \multicolumn{5}{|l|}{ Point DC scheme } \\
\hline Difference in average replacement rate (in \% points) & -7 & -10 & -12 & -13 \\
\hline Difference in service value (in \%) & -4 & -14 & -18 & -21 \\
\hline
\end{tabular}

Note: The scheme is balanced in the baseline scenario. The productivity shock is a reduction in the growth rate of the real wage by 1 percentage point. The migration shock is a permanent negative shock. The size of the cohort entering the labour market (aged 20) is lowered permanently by $5 \%$. In the long run the labour force is $5 \%$ lower than in the baseline. The ageing shock induces a fall in the support ratio from 2.3 to 1.5 in the long run. The average pension is the annual average of pensions among all pensioners. The average replacement rate is the average pension over the annual average wage among all workers.

Source: OECD simulations; Fall (2014), "Comparing the Robustness of PAYG Pension Schemes", OECD Economics Department Working Papers, No. 1134.

\section{The impact of a migration shock}

The migration shock is a permanent negative shock. From the initial year of the shock, the size of the cohort entering the labour market (aged 20) is lowered permanently by $5 \% .40$ years later all working cohorts are $5 \%$ smaller than in the baseline. The support ratio (contributors per pensioner) decreases continuously from the initial year of the shock to year 40 as the cohorts of lower size age. 40 years after the shock, these smaller cohorts start retiring which improves the support ratio progressively. 70 years after the shock, all retired cohorts are $5 \%$ smaller than in the baseline.

The impact of the negative migration shock on the balance of the DB scheme follows the evolution of the support ratio and is temporary. From the initial year of the shock to year 40 the balance of the scheme deteriorates. Then, as these cohorts of lower size retire, the support ratio improves and so does the balance of the scheme. In the long run, the DB scheme reverts to balance.

The DC point scheme is balanced by definition. The negative impact of the migration shock is absorbed by declining pensions. As revenues of the scheme decline, the service value of the point is reduced to balance the scheme. The average pension decreases in line with contributions and stays below the baseline in the long run. 


\section{Box 4. Key features of two stylised pension models and their reaction to shocks (cont.)}

\section{The impact of ageing}

The demographic shock scenario corresponds to a longevity shock. The longevity shock induces a fall of the support ratio from 2.3 to 1.5 in the long run.

In the DB scheme, ageing induces a progressive deterioration of the balance of the scheme. The average replacement rate (the ratio of the average pension to the average wage) in the ageing scenario is lower than in the baseline due to a decline in the average pension, reflecting the fact that pensions are averaged among all cohorts in retirement, with the oldest pensioner cohorts having lower pensions than younger cohorts as pensions are indexed to prices, rather than wages.

The DC point scheme is balanced by definition. The negative effect of the same ageing process is reflected in a decline in the replacement rate. The decline in the replacement rate is larger than for the DB scheme. Also, the service value of the point diminishes in line with the support ratio whereas the purchasing value of the point - defined as the price of one unit of differed life annuity - increases with life expectancy. Therefore, individuals gain a lower number of points at a lower service value. The adjustment of the point values keeps the scheme in balance.

\section{Reforming PAYG pension schemes to cope with ageing}

To maintain the sustainability of pension systems in the face of an ageing population, governments have the following policy options: they can increase the contribution rate, decrease the pension rate or increase the retirement age.

Increasing the contribution rate generates more immediate revenues. However, this policy affects the balance of DC and DB schemes differently as higher contribution rates raise pension rights in the former (in the absence of other adjustments) but not in the latter. Public pension contribution rates (employee plus employer's contributions) have remained broadly stable since the mid-1990s (OECD, 2013b). The only significant increase in contribution rates was in the Czech Republic. Concerns over the effect of higher labour taxes on employment have acted against raising contribution rates further in the other countries.

The impact of ageing is accentuated by generous pension benefits in some countries, especially in PAYG DB schemes. In that case, reducing the pension rate lowers pension spending and improves financial sustainability. This can be done in an ad-hoc way, but in some countries, pension benefits can be reduced through indexation rules, which take into account financial imbalances (Canada, Germany, Japan, Portugal and Sweden).

Increasing the retirement age has been one of the most often used measures to improve the financial health of pension schemes. The official retirement age has already been increased or is legislated to increase in most OECD countries, with increases programmed for men in 19 countries and for women in 23 countries. The Netherlands, Poland and Sweden plan to raise the pension age, while in Iceland and Norway, the pension age is already 67 . While 65 is the current retirement age in half of the OECD countries, 13 countries are moving towards 67 or higher. The official retirement age is projected to reach 69 in Denmark and Italy by 2050 thanks to the link with life expectancy. Luxembourg (60), France and the Slovak Republic (62 both) have the lowest pensionable age for men and Chile, Luxembourg and Poland (60) for women.

The implications of reforms are illustrated for PAYG schemes using again the two stylised pension models (Box 5). 


\section{Box 5. Pension reforms to cope with an ageing shock}

\section{The impact of increasing the contribution rate in the two schemes}

In the $\mathrm{DB}$ scheme, the contribution rate needs to be increased by 5 percentage points as compared to the baseline to cope with the ageing shock (Table 2). In the long run, the balance of the DB scheme reverts to the baseline level.

In the point DC scheme, the contribution rate is increased by the same amount as in the DB scheme. Increasing the contribution rate limits the reduction in the average replacement rate due to the ageing shock to 5 percentage points (against a 13 percentage point reduction in the ageing scenario). However, as the contribution rate is increased, the service value of the point decreases to keep the point scheme in balance.

Table 2. Reforming PAYG schemes to cope with the ageing shock Difference with respect to baseline

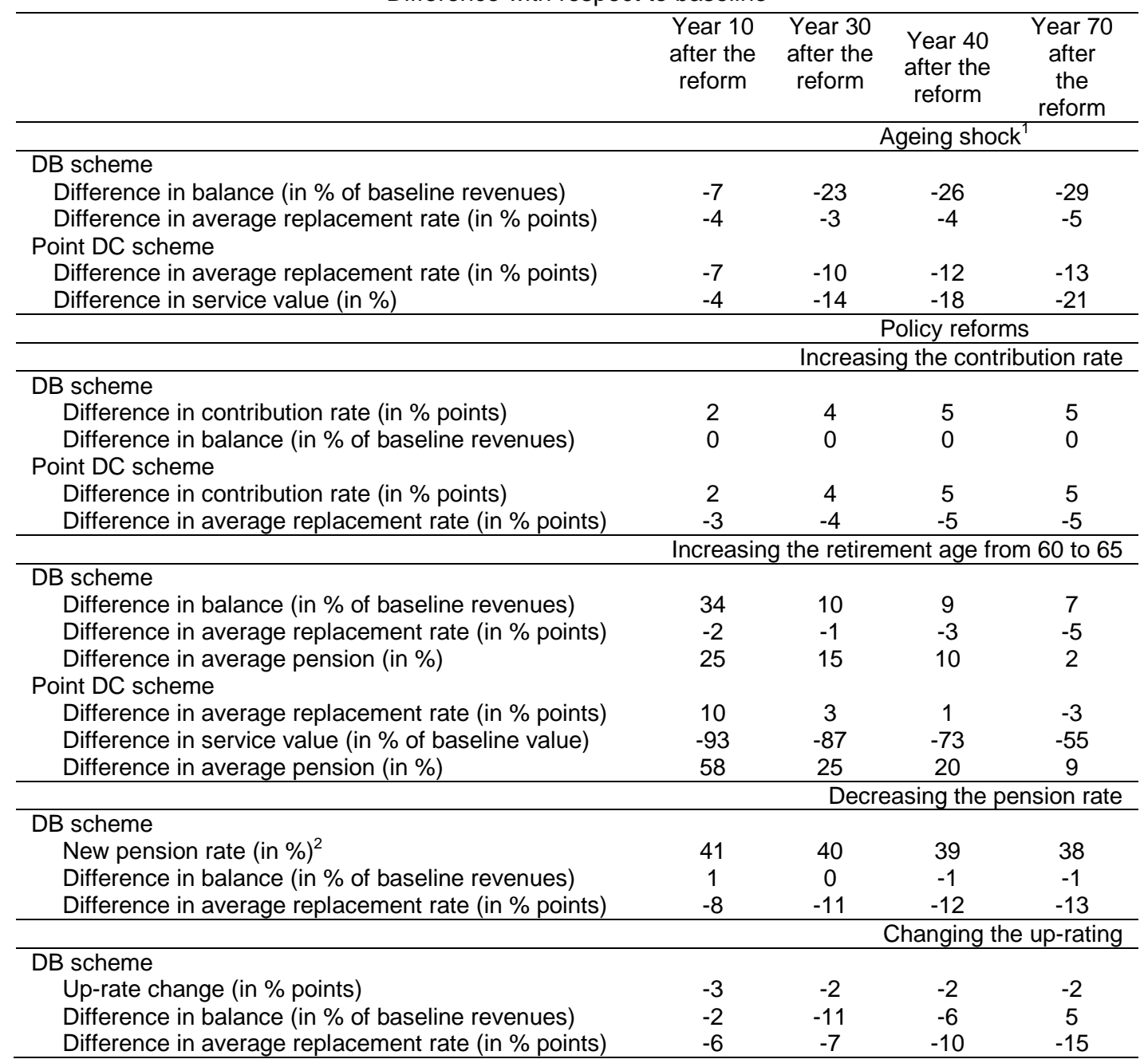

Note: The impacts of the reforms are expressed in differences from the baseline scenario and should be compared with the impact of the ageing shock (at the top of the table). The simulation results show how much the reforms counteract the effect of the ageing shock as compared with the baseline.

1. The ageing shock is the same as in Table 1. It is repeated to make comparisons easier.

2. The new pension rate is the rate that brings the scheme into balance. The pension rate is $50 \%$ in the baseline scenario. Source: OECD simulations; Fall (2014), "Comparing the Robustness of PAYG Pension Schemes", OECD Economics Department Working Papers, No. 1134. 


\section{Box 5. Pension reforms to cope with an ageing shock (cont.)}

Increasing the contribution rate alone is not the best way of adjusting the balance of the point scheme. In principle, it is the purchasing value and/or the service value of the point that is adjusted to ensure the actuarial balance of the scheme. However, in some countries, the short-run funding needs are financed by increasing the contribution rate but the additional contributions do not generate additional pension rights.

\section{Increasing the retirement age in the two schemes}

A higher retirement age lowers pension payments as the number of cohorts in retirement diminishes. The retirement age increase is put in place swiftly from age 60 to age 65 in the first year of the reform. In the long run, the deficit due to ageing is reduced from $29 \%$ to a surplus of $7 \%$ of baseline revenues in the DB scheme. In the short run, the reform improves the balance of the scheme because the revenues increase swiftly while the spending increases progressively with the retirement of cohorts with 45 years of contributions. However, when increasing the retirement age, the average replacement rate is lower than in the baseline scenario without ageing due to the increase of the average wage. But, the pension level is still 2 percentage points higher in the increasing retirement age scenario.

However, the final outcome for individual pension benefits depends on labour market developments. Increasing the official retirement age is not enough. Options for early retirement also need to be removed. Well-functioning labour markets and targeted policies to increase the employment of older workers are key factors to raise the employment of older workers. Otherwise, lower pension spending would be offset by higher spending on other social programmes.

In the point scheme, increasing the retirement age induces an increase in pension benefits as compared with the baseline by 9 percentage points over the long run. Also, the average replacement rate is only 3 percentage points below that of the baseline against 13 percentage points in the ageing scenario. The service value of the point goes down considerably to balance the point DC scheme.

\section{Decreasing the pension rate to balance a DB scheme}

The pension rate is reduced by more than 10 percentage points from $50 \%$ to $38 \%$ to fully counteract the ageing shock. The impact on the replacement rate is large as the average replacement rate declines by 13 percentage points in the long run.

\section{Changing the up-rating of past wages in the DB scheme}

In the DB scheme, the pension at retirement is calculated based on the average career wage. The calculation of the career average wage is done by up rating past wages to the retirement year with the growth rate of the economy-wide average wage. The reform consists of up-rating with inflation instead of the average wage growth rate. As the inflation rate is lower than the average wage growth rate, the reform induces a decrease of the individual average career wage and then of the pension level at retirement.

On average, the reform reduces the up-rating rate by 1.75 percentage points. The balance of the DB scheme improves progressively (compared to the ageing shock scenario) and in the long run it improves by $5 \%$ of baseline revenues, while the average replacement rate decreases by 15 percentage points. 


\section{Automatic adjustment mechanisms can shelter pension systems from the ageing shock}

Many OECD countries have introduced automatic adjustment mechanisms to cope with ageing (Table 3). For instance, Sweden automatically adjusts benefit levels through downward changes in the return on accumulated notional capital and revaluation of current pensions when the balancing ratio (present and futures resources over liabilities of the pension system) is below one. Automatic adjustment mechanisms are an alternative to frequent and difficult pension reforms (Box 6) and create greater clarity about the future shape of the pension system.

\section{Table 3. Automatic adjustment mechanisms to ensure the sustainability of pension} schemes

\begin{tabular}{|c|c|c|c|c|}
\hline & $\begin{array}{c}\text { Link of } \\
\text { pension } \\
\text { benefit to life } \\
\text { expectancy }\end{array}$ & $\begin{array}{c}\text { Pension } \\
\text { valorisation and } \\
\text { indexation }\end{array}$ & $\begin{array}{l}\text { Retirement } \\
\text { age }\end{array}$ & $\begin{array}{l}\text { Contribution } \\
\text { rate }\end{array}$ \\
\hline Australia & $x$ & & & \\
\hline Canada & $x$ & $x$ & & $x$ \\
\hline Chile & $x$ & & & \\
\hline Czech Republic & & & $x$ & \\
\hline Denmark & & & $x$ & \\
\hline Estonia & $x$ & & & \\
\hline Finland & $x$ & & & \\
\hline France & & & $x^{1}$ & \\
\hline Germany & $x$ & $x$ & & $x$ \\
\hline Greece & & & $x$ & \\
\hline Ireland & $x$ & & & \\
\hline Israel & $x$ & & & \\
\hline Italy & $x$ & & $x$ & \\
\hline Japan & $x$ & $x$ & & $x^{2}$ \\
\hline Mexico & $x$ & & & \\
\hline Netherlands & & & $x^{3}$ & \\
\hline Norway & $x$ & & & \\
\hline Poland & $x$ & & & \\
\hline Portugal & $x$ & $x$ & & \\
\hline Slovak Republic & $x$ & & & \\
\hline Sweden & $x$ & $x$ & & \\
\hline United Kingdom & $x$ & & & \\
\hline United States & $x$ & & & \\
\hline
\end{tabular}

Note: Pension valorisation refers to rates applied to past contributions or past wages in DB schemes that determine their value at the retirement date. Indexation refers to annual pension increases, including rates of return in NDC schemes. Link of pension benefit to life expectancy may be partial.

1. For France, it is the contribution period for the receipt of a full pension which is linked to life expectancy and the adjustment is not completely automatic as the government has to enact it.

2. For Japan, the measures are temporary up to 2017.

3. For the Netherlands, the retirement age will be adjusted to life expectancy from 2023 after the pension age has gradually increased to 67 years.

Source: OECD (2012), OECD Pensions Outlook 2012.

Three key variables (the pension level, the pensionable age or the contribution rate) can be adjusted to bring the sustainability of pension systems in line with changes in life expectancy. In Finland, the life expectancy coefficient automatically adjusts pension payments as life expectancy changes. In notional defined-contribution schemes (Sweden, Chile, Estonia, Mexico and Italy) and some defined-contribution plans, accumulated contributions and investment returns are converted 
into a pension or annuity in retirement, with the conversion factor depending on life expectancy. Canada and Germany are two countries, with several adjustment mechanisms. In Germany, for instance, benefits can become lower, but not go below $40 \%$ of the average wage, while the contribution rate can go up, but not beyond $21 \%$. Still, ten countries do not have automatic adjustment mechanisms linked to gains in life expectancy. However, in most of these countries, the retirement age is already planned to increase.

\section{Box 6. Political economy of reforms: Independent bodies and consensus building}

Different factors shape the success of pension reforms. Having an independent body in charge of the assessment of pension schemes, of the projections of pension expenditure and the evaluation of the impact of demographic changes is very helpful at least for the diagnosis and acceptance of the need for reform (EU-EPC-AWG projections; France, Sweden and Belgium among others have independent bodies in charge of the assessment of the pension system). ${ }^{1}$ Ad hoc Commissions also played an important role (Germany, Sweden and United Kingdom) in preparing reforms and building consensus. Building trust in such institutions can take time, as their effectiveness depends greatly on their reputation, but in countries where they exist, it appears that they have enhanced the prospects for reform (Tompson, 2009).

Economic and financial crises may make pension reforms inevitable (OECD, 2010). In deep recessions, the fall in pension contributions, which are typically linked to the payroll, may threaten the payment of pension benefits (Greece during the crisis), unless compensatory transfers from the central government are provided. Crisis may thus make an increase in the retirement age or a reduction in pension benefits, at a time when sacrifices are necessary also elsewhere in the economy, more acceptable.

The success of reforms depends on country-specific factors and the national political landscape. However, OECD (2010) shows that there are common factors that favour success. For instance, sequencing measures affecting different groups is a strategy that has been successfully applied in pension and other reforms. However, sequencing implies that it may take time to accomplish the overall agenda. The French pension reform started in 1993 with changes in pension rules, in 2003 contribution periods were increased, in 2008 special regimes were reformed, in 2010 the retirement age was increased and in 2013 contribution periods were further increased and contribution rates are planned to rise. In the Swedish case pension reform was an overhaul started by setting up a commission in 1991, but the first payment of pensions under the new scheme started only in 2003.

1. Hagemann (2011) and Curristine et al. (2013) review fiscal council functions and impacts.

\section{Policies to safeguard the sustainability of funded schemes}

\section{Prudential regulation and assets price and interest rate risks}

Prudential regulation is important for safeguarding the financial sustainability of pension schemes, especially private ones, facing large financial market risks. Among the instruments of regulation used in the different countries are some restrictions or limits on investments in different asset classes and minimum funding ratios (Fall and Bloch, 2014). Prudential regulation faces a tradeoff between preventing excessive risk-taking and allowing for sufficiently high returns on investments to provide adequate pensions.

The recent economic crisis precipitated a large fall in asset prices and showed the importance of protecting pension assets, in particular those of older workers. Private pension funds in the OECD countries had an aggregate loss of $23 \%$ of their real value in 2008 (D'Addio et al., 2009). As an individual gets closer to retirement or is already in retirement it makes sense that a higher proportion of their pension capital should be invested in safer assets even though they have lower returns. Investment strategies based on this life-cycle approach should be the default investment strategy, as 
shown by OECD work, using a stochastic model (Antolín et al., 2010). Also, in voluntary and occupational private plans, including life insurance, individuals should be encouraged to annuitise their withdrawal from schemes as a protection against longevity risk.

Private plans should be sufficiently well-funded. While full funding exists in principle for defined-contribution plans, other types of plans should be subject to minimum funding rules or other mechanisms to ensure adequate funding of pension liabilities (OECD, 2011b). The funding ratio requirements should be flexible given the long-term liabilities of pension plans. The funding ratio or activation for additional capitalisation is normally stricter for defined-benefit pension plans. In addition, countries may need to have funding rules that seek to assure that plan assets at least equal all promised benefits to date if the plan were to be wound-up (the accumulated benefit obligation or termination liability). Pension funds in Portugal, Germany, Sweden and Norway were overfunded in 2010 and 2011 with an average funding ratio around 110\% (Fall and Bloch, 2014). In contrast, pension funds were underfunded at the end of 2011 in the Netherlands, Austria and Iceland.

The funding standard has an important impact on the investment strategy followed by private pension plans. In particular for occupational defined-benefit plans where the liabilities are borne ultimately by the sponsors, clear rules and guidance should be in place to avoid the underestimation of the liabilities. Prudential ratios require the sponsors to adjust the funding in line with the liabilities and the performance of the plans.

\section{Private occupational pension plans and DC schemes should be covered by an insurance mechanism}

Despite funding standards, following economic or asset prices shocks there is a tail risk that private pension plans may become unable to fulfil their pension promises. For instance, if an enterprise sponsoring an occupational pension plan goes bankrupt, it is unable to honour its liabilities vis-à-vis the pension plan. To protect individuals from these shocks an insurance mechanism is in place in some countries. Such schemes exist, for instance, in the United States, Sweden, Germany, Ontario - Canada, Switzerland, Japan and in the United Kingdom, more recently. For instance, in the United States, in 2012 the Pension Benefit Guaranty Corporation (PBGC) assumed responsibility for 47000 people in 155 failed single-employer plans and started paying benefits to the 17000 retirees in those plans (PBGC, 2012).

The existence of such schemes can lead to moral hazard, adverse selection and potentially systemic risk (as bankruptcies tend to be correlated). One of the key conclusions from Stewart's (2007) analysis is that, to work effectively, these schemes must be independent and have powers to set and collect appropriately risk-adjusted premiums - but they also need to be considered along with other benefit protection policies (notably effective funding rules). For instance, the PBGC in the United States is running deficits since 2002, partly because it has not sufficient powers to control the benefits paid or the premiums charged.

\section{Pension adequacy is key to combat old-age poverty}

Because of high rates of old age poverty, the adequacy of pensions is already an issue in some OECD countries (Fall and Bloch, 2014). On average, 13\% of the over 65 year olds live in income poverty, defined as an income below half the national median income. In 2010, poverty rates of people aged over 65 were very high in Korea (47\%), Australia (36\%) and Mexico (28\%). 4 Moreover, in lower income countries with many workers in the informal sector and thus not enrolled in a pension scheme, the coverage rate is still low. Only about $60 \%$ of the labour force is covered in Chile and Turkey, and less than $50 \%$ in Mexico (OECD, 2012b). This means that many people will reach pensionable age with little or no pension entitlement.

4. For some countries, the poverty indicator based on income may not give an accurate measure of individual's deprivation. In particular, the elderly often have financial and non-financial assets, such as housing that limits the impact of lower income on living standards. 
Pension adequacy is poised to become an even more burning issue in the future. Reforms of public pension schemes recently implemented imply that replacement rates will decline by $23 \%$ on average for workers with average earnings compared to pre-reform level (OECD, 2012b). In 21 OECD countries, replacement rates are not expected to reach $60 \%$ for workers on average earnings. Even for low income workers (those with half of average earnings), there are eleven countries for which the replacement rate is expected to fall below 60\% (OECD, 2012b). While improving sustainability, recent reforms risk increasing old age poverty.

Lower pension adequacy may transfer the ageing cost to social assistance. Safety net transfers exist in almost all OECD countries to prevent poverty. Old age safety nets are in general means-tested and designed to complement pensions. There are three types of benefits: a non-contributory benefit in 21 countries including the Netherlands and New Zealand, where basic pensions are residencytested; a targeted safety-net income in 13 countries; and a contributory minimum pension defined as the minimum income of a low-earning, full-career worker.

In some countries, elderly individuals receive either a non-contributory benefit (basic or targeted benefit) or a minimum pension (Fall and Bloch, 2014). In Greece, for example, some $60 \%$ of older people are on the contributory minimum pension and a further $19 \%$ on safety-net benefits, with slightly lower proportions for both kinds of schemes in Portugal. Nearly $80 \%$ of Australians receive at least some payment from the resource-tested scheme and nearly $90 \%$ in Denmark. In Finland, France and Sweden, minimum contributory benefits are the most significant, covering $37-47 \%$ of retirees (OECD, 2013b).

\section{There is scope to broaden private pension coverage to support old age income}

Increasing the coverage of private pensions can help to cope with the ageing shock without affecting social budgets. Funded private pensions play already an important complementary role for pension adequacy in Canada, Ireland, the United Kingdom and the United States. Income from capital, predominantly private pensions, accounts for between $25 \%$ of income of the over-65 year olds in Ireland and 40\% in Canada. The OECD's pension gap analysis (OECD, 2013b) compares future replacement rates of mandatory pension schemes with average earnings. Among the countries with a big pension gap, some already have old age poverty rates above the OECD average (Australia, Mexico, the United States, Chile, Japan and Slovenia), illustrating the need to increase the coverage of low income earners or workers in the informal sector.

Increasing the coverage of private pensions can be achieved through compulsion, softcompulsion via automatic enrolment, or improving the existing financial incentives (which should be targeted at low income people). Compulsion is the most effective approach to increase the coverage of private pensions (OECD, 2012b). Automatic enrolment is a second-best. Its success in increasing coverage depends on how it is designed and on its interaction with incentives in the system. Among countries with voluntary private pensions, New Zealand has experienced a substantial increase in coverage thanks to the introduction of automatic enrolment and government subsidies ("KiwiSaver scheme").

\section{Challenges for the BRIICS countries}

Although the demographic dependency ratio is still favourable in the BRIICS countries, it will converge rapidly to the OECD average, except for South Africa and India (Figure 7). All BRIICS countries are enacting pension reforms or preparing a reform of their pension systems.

Raising pension adequacy is one of the main objectives of the reforms. The most acute challenge is to enrol workers in the informal sector in voluntary pension schemes (India, Indonesia, South Africa and China). Many workers do not earn enough or on a regular basis to contribute to pension schemes. The tools used to incentivise people with low earnings and informal workers to save for retirement are co-payments and tax incentives. These instruments may, however, weigh on budget resources and undermine sustainability. 
Financial sustainability issues are already present in all the countries due to generous pensions (Brazil), insufficient funding and fragmentation (China), early retirement (Indonesia), carry-over of unfunded past liabilities (India and Russia) and important safety net benefits (South Africa). In Brazil, Russia and South Africa, the coverage of old age benefits were broadened and benefits were increased to tackle old age poverty. The coverage is almost universal in Brazil and reaches $75 \%$ of those aged 60 and above in South Africa. Improved adequacy of the pension system has been achieved at the expense of the public finances as these benefits are budget funded. In Indonesia, particularly generous early retirement rules are threatening the financial sustainability of pension schemes.

\section{Overcoming vulnerabilities of health care systems}

Assessing the effects of shocks on health care systems is challenging for various reasons. Unlike pension and unemployment insurance schemes, the overall functioning of health care systems is not governed by specific parameters, which can help quantifying the effects of adverse shocks on their sustainability and adequacy. Also, health care system characteristics vary greatly across OECD countries (Paris et al., 2010) and it is not clear how they affect the vulnerability of health care systems to shocks. For instance, Joumard et al. (2010) have identified six types of health care systems and underlined that none of them systematically outperforms the others in terms of delivering health care services in an efficient way.

Policies to make the health care system more resilient to shocks can be grouped according to whether they help dealing with adverse long-term trends or temporary shocks.

\section{Long-term trends}

Over the long run, the main source of vulnerability relates to the main drivers of spending, which are ageing, income, and price and technology developments (de la Maisonneuve and Oliveira and Martins, 2013). Policy improvements could make health care systems more robust to shocks and help bringing about the large health care efficiency gains estimated in previous OECD studies (Joumard et al., 2010 and Hribernik and Kierzenkowski, 2013). Efficiency savings could offset future spending pressures, therefore counteracting the effect of adverse long-term trends.

The adoption of best practices (Box 7) could yield sizable public health care savings (Pisu, 2014 discusses reform options in more detail). According to the latest OECD efficiency estimates (Hribernik and Kierzenkowski, 2013), OECD countries could lower health care spending by about a third, while maintaining the same health outcomes. Achieving such efficiency gains could significantly help in curbing public health care spending pressures in the coming years. Countries with the highest potential savings are characterised by a large projected increase in health spending, large inefficiencies or both (e.g. United States, Germany and Austria). For other countries (such as Korea and Chile) potential health expenditure savings are much smaller, but still sizeable.

Health care reforms, like other social policy reforms, are characterised by strong path dependence (Wilsford, 1994). This will make it challenging to achieve large savings in the short term, as these would require radical changes. However, these estimates provide a rough gauge of the magnitude of savings countries could reap by moving towards the efficiency frontier through incremental policy changes. 


\section{Box 7. Review of policies to contain the secular increase in health care spending}

Several OECD countries have adopted budgetary caps of different forms. Countries with an integrated health care system, relying on public provision and insurance (i.e. the financing and supply of health care are managed by the same entity) have the most stringent budget controls. Some countries with social insurance-based health care systems (e.g. Belgium, France, Luxembourg) also apply budgetary caps, which, however, provide indicative rather than binding targets. ${ }^{1}$ de la Maisonneuve et al. (2014) provide evidence that stringent budget constraints help curbing the growth of health care spending (Pisu, 2014).

Moving away from volume-incentive payment methods (e.g. fee for service) would help contain the rising demand for and supply of health care services associated with rising incomes. Payment for hospital care based on patient characteristics - e.g. diagnosis-related groups (DRGs) - contribute to improving the sustainability of health care systems. These payment methods provide strong incentives to reduce unnecessary tests and treatments without negatively affecting the quality of care.

More competition among health care providers, accompanied by strong and effective regulation, can curb spending growth and improve the quality of care. Regulated competition can strengthen incentives to achieve efficiency gains, better align health care service characteristics with patient preferences and promote access to care (with, for instance, means-tested subsidised insurance premiums). Strict regulation, enforcing quality standards and promoting access to care is, however, paramount to achieve these outcomes as unfettered market forces will lead to low-quality services because of asymmetric information and under-provision for the most vulnerable segments of the population because of inability to pay. Empirical evidence suggests that regulated competition among hospitals (Gaynor et al., 2013; Cooper et al., 2011; Kessler and McClellan, 2000) can lower expenditure, enhance the quality of care, or both.

OECD countries have used, to a different extent, workforce supply and wage controls to curb the ever-rising costs of health care personnel. ${ }^{2}$ In the short term, wage controls can be effective in containing spending. Countries with public-integrated systems and where health-care personnel is paid on a salary basis (e.g. Denmark, Finland, Ireland, Spain, Sweden, the United Kingdom) have used these policies more frequently than others (Docteur and Oxley, 2003). Workforce supply controls, through entry regulations for medical schools for instance, have instead been less effective. The experience of some countries is that personnel supply restrictions can lead to wage pressures. Also, the experience of Finland in the early 1990s shows that imposing supply restrictions in the wake of a severe economic shock can have adverse long-term effects. The reduction in the number of doctors resulted in fewer medical students and eventually in an insufficient number of doctors that has yet to be fully reversed (OECD, 2012c).

Relying heavily on cost sharing to reduce health care demand is inefficient and inequitable. Raising cost sharing may help curb public expenditure in the short term, but it also tends to be regressive and worsens adequacy of services for the least well off. Cost sharing shifts health risks back to individuals, thus reducing risk pooling. All OECD countries rely on cost sharing. Greece, Korea and Mexico rely on cost sharing the most whereas the Netherlands, Luxembourg and France the least. A high degree of cost sharing is likely to induce poor people to postpone or forego necessary treatments and reduce preventive care, therefore leading to higher spending in the future.

Decentralisation in service delivery coupled with at least some central-government financing could provide the benefits of both decentralised and centralised systems while avoiding their drawbacks. On the one hand, central financing would shelter local authorities from a drastic drop in local revenues and prevent large interregional disparities in health-care spending. On the other hand, local responsibility for health care delivery could permit to better tailor health services to local needs, stimulate competition among local jurisdictions and promote experimentation of new practices that could eventually be extended to the national level.

1. In these systems, targets are based on the expected social insurance contributions, with the government having limited control over them.

2. Baumol (1996) dubbed this phenomenon the "cost disease" and ascribed it to the stagnant labour productivity of the health care sector accompanied by regular wage increases. 
Ageing

Longevity gains are a source of vulnerability for health care systems. If longevity gains do not translate into additional years of good health, the projected health spending-to-GDP ratio in 2060 will be 1.2 and $2.3 \%$ percentage points higher for the OECD and BRIICS countries, respectively (under the cost pressure scenario).

Prevention policies and those that encourage healthier lifestyles can be effective in mitigating vulnerabilities associated with an ageing population and the growth in chronic conditions. By augmenting the number of years spent in good health, these policies will help avoiding that ageing results in a rising share of old people needing health and long-term care. These policies include a variety of interventions such as: information campaigns; the use of market mechanisms to influence the consumption of certain goods and services; health standards and bans of goods and services (Pisu, 2014).

"Sin" taxes have received growing attention as a way to discourage unhealthy behaviour and to finance health care. These taxes can be highly effective in discouraging unhealthy behaviour. There is robust evidence on the impact of taxes for tobacco and alcoholic beverages, while in the case of taxes on food, the effectiveness of the tax depends on its design (Sassi et al., 2013). The rates of these taxes should be set based on the marginal negative externalities generated by the goods they apply to. Raising them to match the growth of health care spending would risk creating large distortions as these would have to go far above their optimal rates (Heady, 2013).

\section{Technology and price developments}

The introduction of new expensive technologies in health care is one of the main causes of escalating health care costs. Health Technology Assessment (HTA) can be a useful instrument to rigorously evaluate the costs and benefits of new technologies and therapies with the aim of identifying those that are most cost effective. HTAs can help in shaping healthcare guidelines (e.g. inclusion of drugs in pharmaceutical formularies), cost-sharing schedules (e.g. lower user charges for cost-effective preventive interventions) and the definition of publicly funded benefit packages.

HTAs can limit the growth in health spending due to new technologies by helping to identify and apply the most cost-effective ones. For instance, more than half of HTA studies conducted in the last 20 years in the United Kingdom found that new technologies are no better than traditional ones (Raftery and Powell, 2013).

As concerns prices, HTA may provide the authorities with better information to negotiate with providers the prices of new treatment and drugs based on sound cost-benefit analyses. Preferred drug lists and mandated generic substitution have proved effective in reducing pharmaceutical spending by identifying and promoting the use of the most cost-effective or cheaper bioequivalent drugs. The evidence indicates that these policies have helped contain public expenditure on pharmaceuticals without worsening service adequacy.

\section{Temporary shocks}

Both the adequacy and financing of health care systems are vulnerable to large temporary personal income and GDP shocks. Personal income shocks can be detrimental especially in countries characterised by a large share of out-of-pocket payments and well-developed private (primary) health insurance markets. Public health spending is countercyclical (Darby and Melitz, 2008; Pisu, 2014) and OECD countries' health care systems have proved to be able to weather normal macroeconomic fluctuations. However, the last crisis is a reminder of the importance of health care system's preparedness to deal with unexpected and prolonged negative GDP shocks. The experience of Greece shows that drastic health spending cuts during economic crises to meet fiscal targets, especially if they are not targeted to reduce ineffective spending, can damage adequacy of services and worsen health outcomes (Stuckler and Basu 2013), which can eventually lead to higher spending. 
For countries relying on private (primary) health insurance, it is important to have policies in place, which ensure that coverage is not unduly affected by economic shocks at the individual level. Negative personal income shocks or unemployment spells can result in lower private health insurance coverage as some may not afford private health insurance premiums any longer (Figure 19). The loss of health care coverage can result in substantial welfare losses. During the latest economic crisis, the United States, for instance, prevented a sharp rise in young adults without health insurance by allowing them to stay on their parents' health insurance plans. Other countries relying heavily on private health insurance, like the Netherlands and Switzerland, have instead been able to guarantee universal health coverage through the individual mandate and targeted subsidies to people who cannot afford insurance premiums.5

\section{Figure 19. Real disposable income shocks affect private health insurance coverage} 2008-11 change

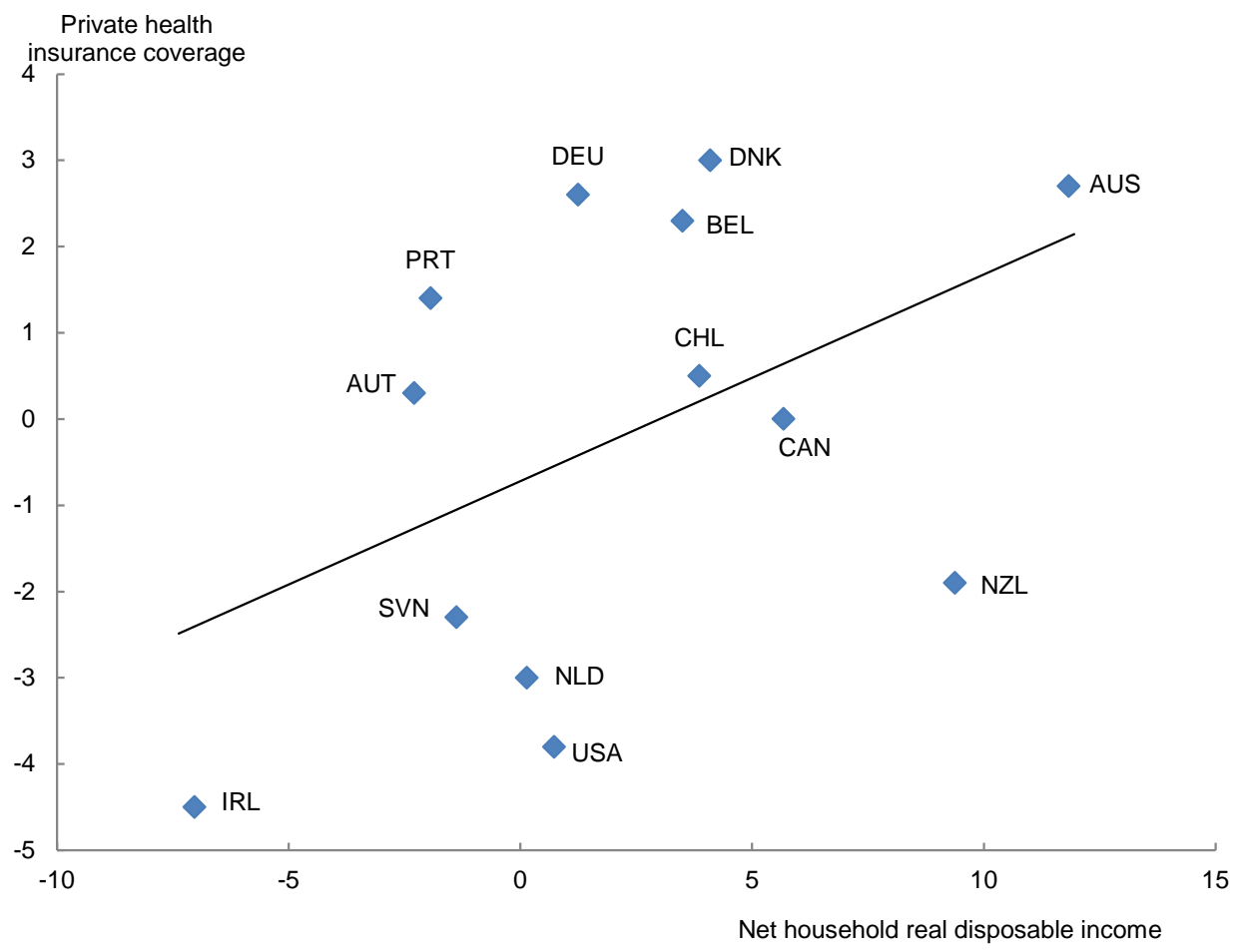

Note: The change in private health insurance coverage is in percentage points; the change in net household real disposable income is in percentage.

Source: OECD Health Statistics (database); OECD (2012), OECD Economic Outlook, Vol. 2012/1.

StatLink -ints http://dx.doi.org/10.1787/888933080808

Over time, repeated or large shocks may worsen the sustainability of health care systems and trigger policy reforms entailing a drop in the adequacy of health care services. Large negative economic shocks can make it impossible to postpone reforms further. For instance, Greece has had to introduce, at an exceptional speed, reforms overhauling its health care system after ignoring efficiency and sustainability issues for many years (Fall et al., 2014). However, hastening policy changes during crisis periods can face strong social and political opposition as they do not allow for a thorough consultation process. Also, deep spending cuts during a crisis, may cut effective health programmes, such as preventive care, and result in a shortage of general medical supplies (e.g. in Greece), which could lower the health status and eventually result in lower potential growth and higher health spending.

5. The individual mandate consists in the obligation of people to enrol in health insurance plans. 
As shown by the experience of Estonia during the last crisis, buffer funds specifically designed for health care systems can be an effective instrument in the face of large adverse GDP shocks. By accumulating funds during good times and spending them during recessions, buffer funds can help avoiding drastic health care cuts during downturns. Estonia was able to smooth health expenditure, even though the revenues of the social health insurance fund collapsed. The share of the population reporting unmet medical needs for cost reasons, rose from 2008 to 2011, but by less than in other OECD countries similarly hard hit by the crisis. Moreover, the use of reserve funds seems to have guaranteed the same level of equity in access to health care services as the poor did not experience a larger increase in unmet medical needs than the rich (Fall et al., 2014).

\section{Challenges for the BRIICS countries}

The health care systems of the BRIICS countries face different challenges from OECD countries. Per capita health spending in BRIICS countries is substantially lower than in the OECD countries. In Indonesia, India and China, it is below 10\% of the OECD average whereas in Russia, South Africa and Brazil it is close to $30 \%$ (Figure 20). Overall, the low risk pooling results in a large share of out-of pocket payments. In Indonesia, India and China out-of-pocket payments account for more than $50 \%$ of total health spending against an OECD average of less than $20 \%$.

Figure 20. Health care spending is low in the BRIICS countries

Average 2006-10

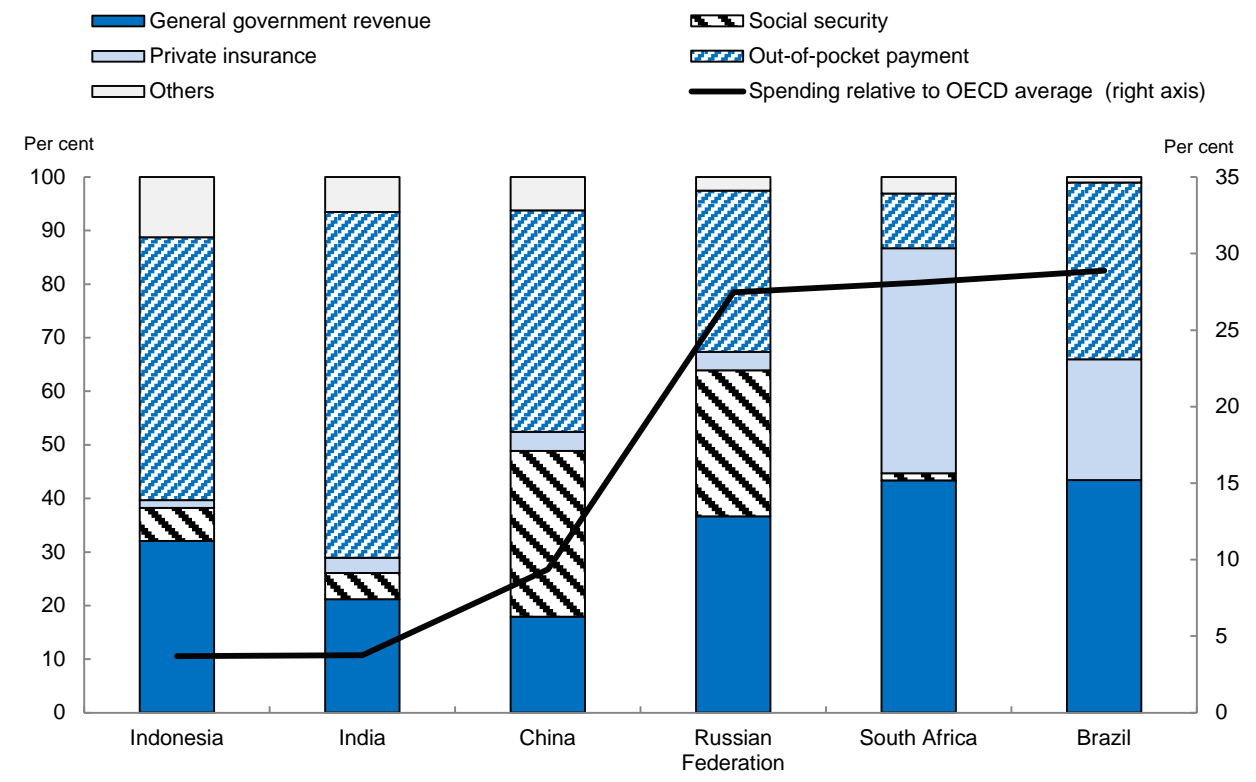

Note: Health care spending relative to the OECD is in per capita 2005 PPP.

Source: World Health Organisation, Global Health Observatory Data Repository.

StatLink तillsh http://dx.doi.org/10.1787/888933080827

The BRIICS countries should enhance service adequacy, by expanding coverage and improving the quality of services. But over the next decades fast population ageing and rising income will make the health care challenges for the BRIICS more similar to those of the OECD countries as the rising demand for better and more equitable services will result in higher health expenditure as a share of GDP (Pisu, 2014).

The development of health technology assessment (HTA) can contribute to reaching the goal of ensuring health coverage for all without excessive cost increases. Adopting HTAs early on in the process of establishing and developing national health systems might allow BRICS countries to avert the steep health care cost increases linked to the extensive use of new expensive technologies that OECD countries have experienced. 
Governments in the BRIICS countries need both to extend their health care systems and adopt policies that will ensure their sustainability, while accommodating demands for more and better quality services. Too high a reliance on out-of-pocket spending may render access to health care services inequitable and discourages the take up of curative and preventive care, especially among the poor. Moreover, by reducing risk pooling, out-of-pocket spending results in a high risk of catastrophically high health expenditure.

The BRIICS countries rely, to a different extent, on social insurance contributions to finance the public health care sector (Pisu, 2014). Increasing the role of general taxation has the potential to make the financing of the health care system less sensitive to fast-ageing populations and to the attendant erosion of the total wage bill due to the rising dependency ratio, more equitable (as general taxation is more progressive than social insurance contributions) and will contribute to increase risk pooling (as general taxation allows for the pooling of risks among all residents and not just among those contributing to the social insurance funds) (e.g. Wagstaff, 2010). There may be an adverse feedback loop between informality and social contributions, with wide-spread labour market informality making it difficult and expensive to collect contributions, which may eventually prevent the attainment of universal coverage, while high contribution rates foster informality.

\section{Overcoming vulnerabilities of unemployment insurance schemes}

The main purposes of unemployment insurance schemes are risk-sharing and redistribution across individuals. In addition, unemployment insurance has a counter-cyclical effect, thus enhancing macroeconomic stability (Andersen, 2012). An unemployment insurance scheme can be said to be resilient even during deep recessions if the system:

- does not run out of funds and does thus not require emergency transfers from the sovereign or resort to emergency rule changes to meet its financial obligations (financial soundness),

- ensures adequate income support to the unemployed according to social preferences (adequacy), and

- $\quad$ supports, or does not unduly hamper return to work, labour market flexibility and productivity growth (efficiency).

Each of these elements is affected both by the settings of an unemployment insurance scheme itself and by the wider labour market institutions in a country. Vulnerabilities are often created by complex interactions between unemployment insurance and other labour market institutions, such as active labour market policies (ALMP), regulations of markets for products and services and wage setting institutions, rather than the set-up of the unemployment insurance per se (Pareliussen, 2014).

\section{Trade-offs between financial sustainability and adequacy}

\section{Replacement rates and benefit duration}

Unemployment insurance is highly counter-cyclical and contributes to dampen negative GDP shocks. When an unemployment shock hits, generous unemployment insurance benefits can shield people from being pushed into poverty and also allow for better job matching. Replacement rates in a number of OECD countries are, however, too low to keep individuals out of relative poverty. When becoming unemployed, a single person with previous in-work earnings of $67 \%$ of the national average wage will, for example, end up living in poverty (50\% of the median wage) in half of the OECD countries. Workless households in the OECD are on average more than seven times as exposed to poverty than households in which at least one of the household members are in work.

While generous unemployment insurance schemes provide a powerful shock absorption mechanism, they can also reduce job search incentives when they are combined with long unemployment insurance duration. This is especially true for low income earners and for those unemployed who are likely to earn a lower wage when re-entering the labour market. Countries who 
offer high initial replacement rates should therefore provide generous benefits only for a short duration to ensure that incentives for job search are not undermined. Countries with the highest generosity in the OECD (Ireland and Austria), exhibit very high initial replacement rates that are also reduced very little for the first five years of unemployment.

\section{Unemployment insurance eligibility criteria}

If eligibility criteria are too strict, unemployment insurance will not perform its core function as a risk sharing tool in the face of an unemployment shock.6 Also the automatic stabilisers will be less powerful. In countries with very strict eligibility criteria, such as Italy and Slovakia,7 a very low percentage of the unemployed is covered by unemployment insurance. Strict eligibility criteria together with labour market duality can further accentuate inequalities between workers on fixed term contracts, which often do not fulfil the eligibility criteria and open-ended contracts, and may disproportionately affect youth. Youth and medium-skilled workers were the most hit by the surge in unemployment since 2009, but the social impact was hardest for the young, who have faced soaring poverty (Figure 21). Countries hard hit by the crisis (such as Estonia, Greece, Spain, Portugal and Italy), have been the least able to shield their youth from rising poverty (Pareliussen, 2014).

Figure 21. Youth poverty has soared during the crisis, while older people were better protected

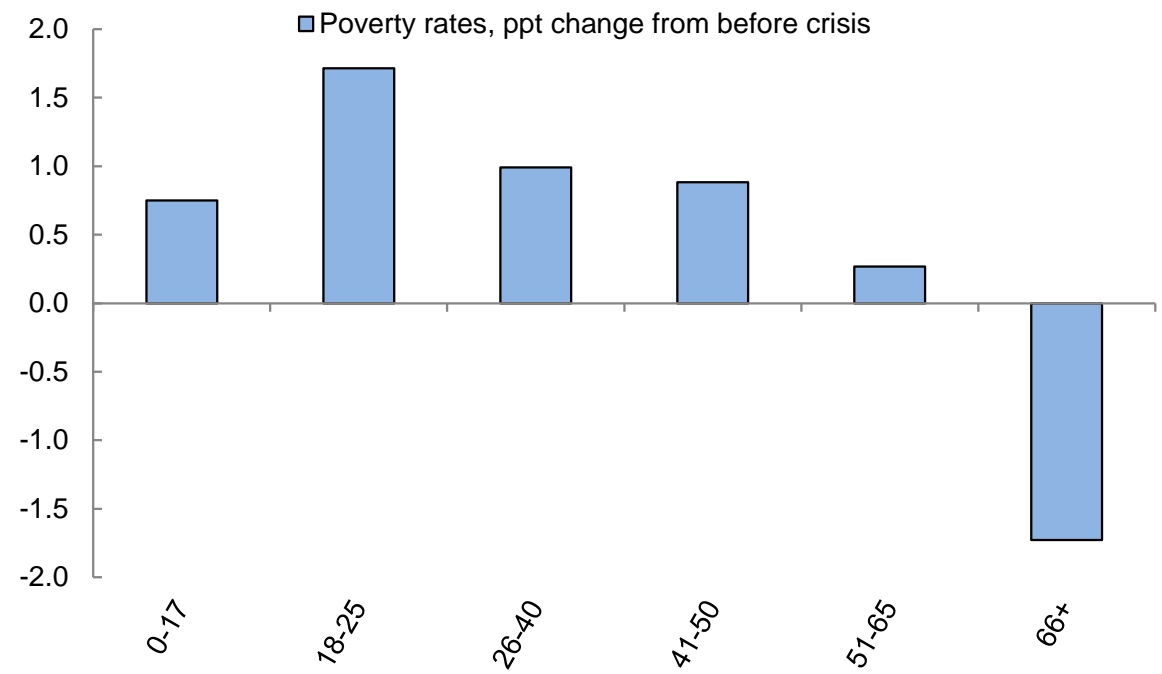

Note: The figure shows the average of 32 OECD countries The poverty rates refer to $50 \%$ of the median income after taxes and transfers, percentage point change from 2007 (2006 for Chile and Japan, 2005 for Switzerland, France, Israel and the United States and 2004 for Australia, Germany, Finland, Mexico, Norway and Sweden) to 2010 (2009 for Switzerland, Chile, Hungary, Ireland, Japan and Turkey).

Source: OECD (2013), "Income Distribution", OECD Social and Welfare Statistics (database), accessed September 2013.

StatLink :inlsh http://dx.doi.org/10.1787/888933080846

6. A well-designed social safety net incentivises labour market entry. This is an argument for applying eligibility criteria, especially in the case of generous unemployment benefits. The average eligibility threshold in the OECD is 11 months of work, unemployment insurance membership or equivalent earnings.

7. In Slovakia unemployment insurance eligibility requires 36 months of working (the highest in the OECD) and in Italy 24. Unemployment insurance duration (total benefits the first five years of unemployment divided by initial monthly benefits) is 2.3 months in Italy and 4.8 months in Slovakia. This is low compared with the OECD average and contributes to low coverage. 


\section{Short-time working schemes}

During the recent crisis, the sensitivity of unemployment to GDP has differed significantly from country to country. While some countries shed a lot of workers and increased productivity (Estonia, Iceland, Ireland and the United States amongst others), others experienced less severe losses of employment, compensated by a fall in hours worked or hourly productivity. In those countries that absorbed the slump mainly through lower output per worker, the labour market consequences have been less severe. In Germany, Luxembourg and Switzerland employment actually increased while GDP fell during the latest recession (Pareliussen, 2014). The design of short-time working schemes is, however, crucial to limit deadweight losses caused by less efficient reallocation of workers and collusion between employers and employees to extract state transfers (Boeri and Bruecker, 2011).

\section{Policies that support both adequacy and financial soundness}

\section{Activation policies}

When a crisis hits, there is a tension between ensuring financial soundness on the one hand and adequate income support for the unemployed on the other. Even though they are costly in the short term, effective activation policies with job search conditionality as the core make it possible to improve financial soundness with a minimum sacrifice of adequacy. They lower the cost borne by individuals who lose their jobs by more efficient matching and shorter unemployment spells. The costs for society are reduced by both higher activity and lower unemployment insurance expenditure (Bassanini and Duval, 2006; Andersen and Svarer, 2007; Andersen, 2012).

Figure 22 shows that activation policies in some of the countries with the strongest rise in unemployment during the recent crisis have probably not been as responsive as required. Strong increases of unemployment combined with fiscal consolidation have left active labour market policies lagging in countries such as Ireland and Spain. These countries already boasted fairly high levels of spending on activation policies, but were not able to increase spending at the same pace as the rise in unemployment. In Mexico, the United States and New Zealand spending on activation policies was relatively low at the outset, and it has not kept pace with the surge in unemployment either. Other countries, such as Hungary, Portugal, Poland and Belgium, have scaled up active labour market policies more than the rise in unemployment. Korea, Slovenia, Estonia and Japan have scaled up activation policies significantly in percentage terms during the crisis, but from very low initial levels compared with the OECD average. 
Figure 22. The responsiveness of active labour market policies to unemployment

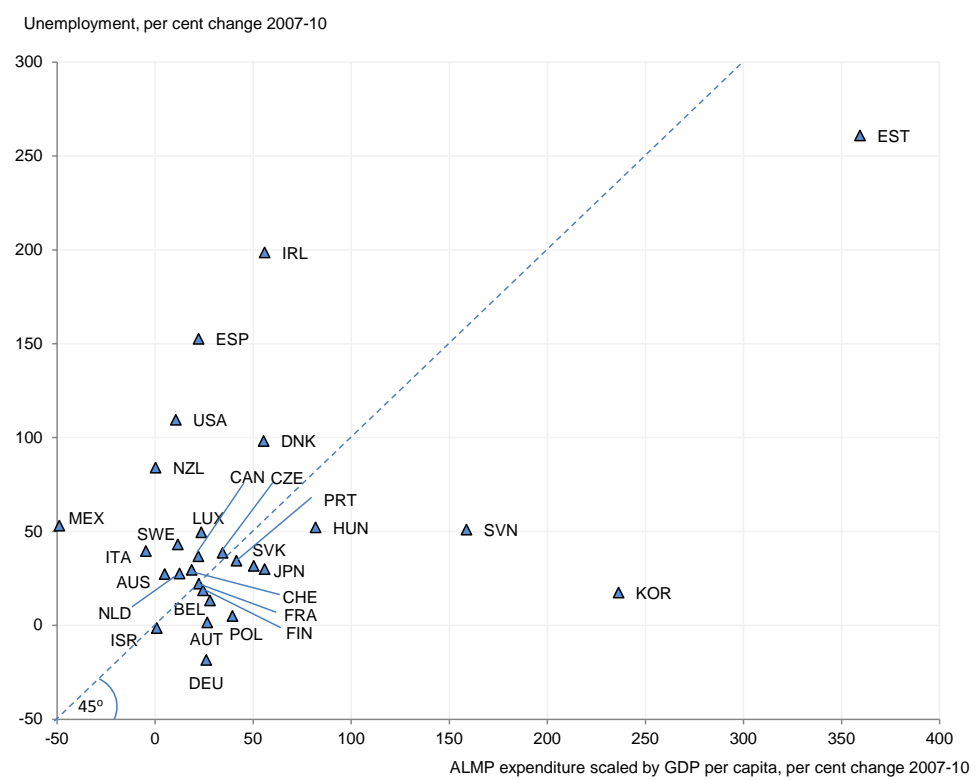

Note: ALMP expenditure is scaled by GDP per capita to ensure comparability across currencies.

Source: OECD (2013), OECD Social Expenditure Statistics (database).

StatLink -inाs http://dx.doi.org/10.1787/888933080865

\section{Closing routes to early retirement and disability schemes}

Early retirement and disability schemes can be a substitute for unemployment insurance. As such, they tend to improve the financial soundness of unemployment insurance schemes, when an unemployment shock hits. But they also undermine both labour supply and potential growth and the sustainability of the overall government finances, because they are not necessarily subject to activation measures and people tend to stay in these schemes until retirement. While curbing inflows into these other benefit schemes will increase unemployment insurance expenditure, it will also increase chances of re-employment, reduce benefit dependency, increase growth and generally also increase earnings prospects for the individuals concerned. The effect on the public finances from curbing inflows to early retirement and disability schemes is likely to be positive, but depends on the generosity of the different benefits and to which extent such curbs raise the employment of older workers, which is still low in many countries (Figure 23). 
Figure 23. Employment and unemployment of older workers

People aged 55 to 64

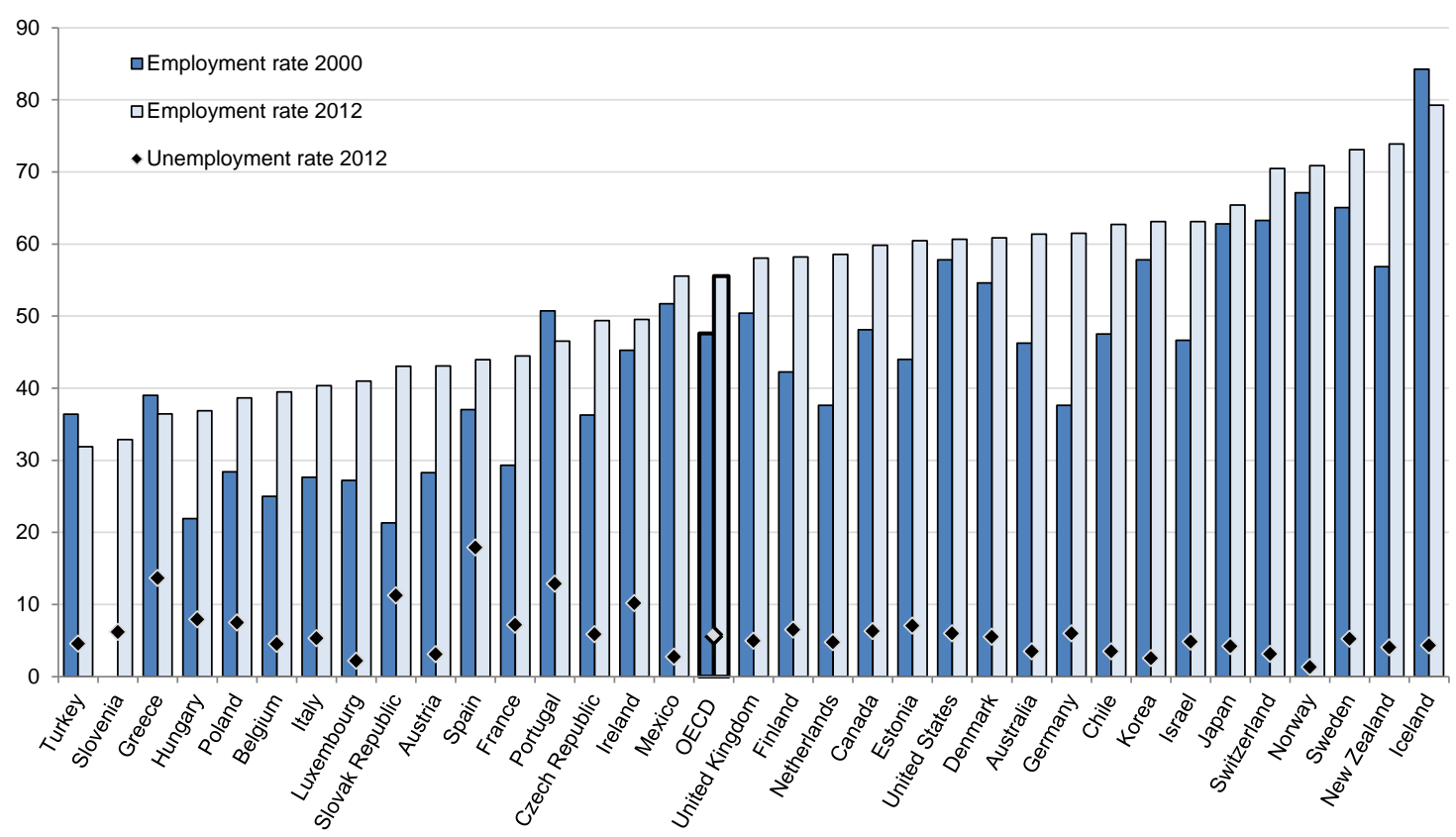

Source: OECD (2014), OECD Employment and Labour Market Statistics (database), accessed 13 January 2014.

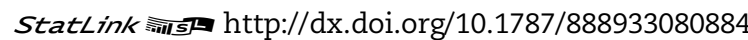

\section{Contingency planning}

\section{Increasing generosity during crises}

Temporary extensions of the maximum period of unemployment benefit receipt may have a useful role to play during a recession, especially in countries where the normal duration of these benefits is relatively low and access of the long-term unemployed to last-resort benefits such as social assistance is limited. There is some evidence that the generosity of unemployment insurance can increase as the unemployment rate rises without detrimental effects, largely due to weaker job search externalities $^{8}$ (De Serres et al., 2012; OECD, 2011a). For the same reasons, a temporary increase in replacement rates during crises in countries where they are low could also be warranted, as a tool to fight poverty and to smooth consumption for cash-strapped individuals. Rules-based adjustments of unemployment benefit parameters during crises feature in the benefit systems of Canada (eligibility criteria, replacement rates and duration), Israel (eligibility criteria) and some states in the United States (duration), while both the United States and Iceland implemented discretionary policies to extend the duration of unemployment insurance during the great recession (OECD, 2011a).

8. As the ratio of unemployed to vacancies increases, vacancies will tend to be filled by a qualified job seeker despite a drop in the job search intensity of each unemployed. In other words, when an unemployed person fills a vacancy during a recession, the person is more likely to crowd out another unemployed person who is also qualified for the position, while in normal times lower search intensity can lead to poorer matching of qualifications to vacancies or vacancies not being filled. 


\section{Social assistance}

Long-term unemployment tends to shoot up during crises and with a slow recovery many individuals could lose their unemployment benefits. While this reduces the vulnerability of unemployment insurance schemes to shocks, this raises the vulnerability of those out of work. Last resort assistance, which is paid out of the general budget, should be available to those in need, on condition that they search for jobs. Such benefits are available in most OECD countries. They are means-tested and provide a last resort for individuals who are not eligible to receive unemployment insurance, individuals who have lost eligibility during the unemployment spell, or as top-ups to the unemployment benefit to cover e.g. housing costs or living expenses in general. If the means-testing of these benefits is too strict, normally self-supporting families who experience long-duration unemployment during a deep recession may encounter difficulties in accessing these benefits or be obliged first to run down their savings or even sell their assets, potentially jeopardising their longterm economic status. This suggests that it is important to pay attention to whether asset tests or other eligibility rules for these programmes are too strict for them to function effectively as a backstop to unemployment insurance during an unemployment shock (OECD, 2011a) in terms of adequacy, hysteresis effects and public finances.

\section{Adjusting the scale and scope of activation policies}

Active labour market policies should be ramped up during crises to cater for the rising number of unemployed. At the same time, while conditionality should be kept as a cornerstone of active labour market policies, some of the resources devoted to promoting and enforcing job search could instead be redirected towards education and training to increase future job prospects, as positive job search externalities are lower during downturns. Several countries have increased the relative importance of training measures during the current downturn, while others where unemployment has increased drastically have moved in the opposite direction. Since it is a challenge to expand capacity quickly without a drop in quality, the active labour market policy administration should plan for contingencies and maintain sufficient resources during good times to be able to scale up effectively during a crisis.

\section{Challenges for the BRIICS countries}

In the BRIICS countries, the poor are very vulnerable to crises, as many of them work in the informal sector or are not eligible to receive income replacement benefits (Figure 24). The consequences of job losses amongst the poor can be very serious, because poor individuals tend to be liquidity constrained, and the vulnerability to shocks may make them adopt an overly risk adverse behaviour (Holzmann and Jørgensen, 2001). Policies designed to increase formality, increase social insurance coverage and make sure that there is a safety net for the poorest individuals could therefore, in addition to stabilise the economy and individual incomes following a shock, increase growth and resilience in the long term. 
Figure 24. Affiliation to social security by earnings quintile in lower income countries Latest available year

口Lower quintile aUpper quintile -Average

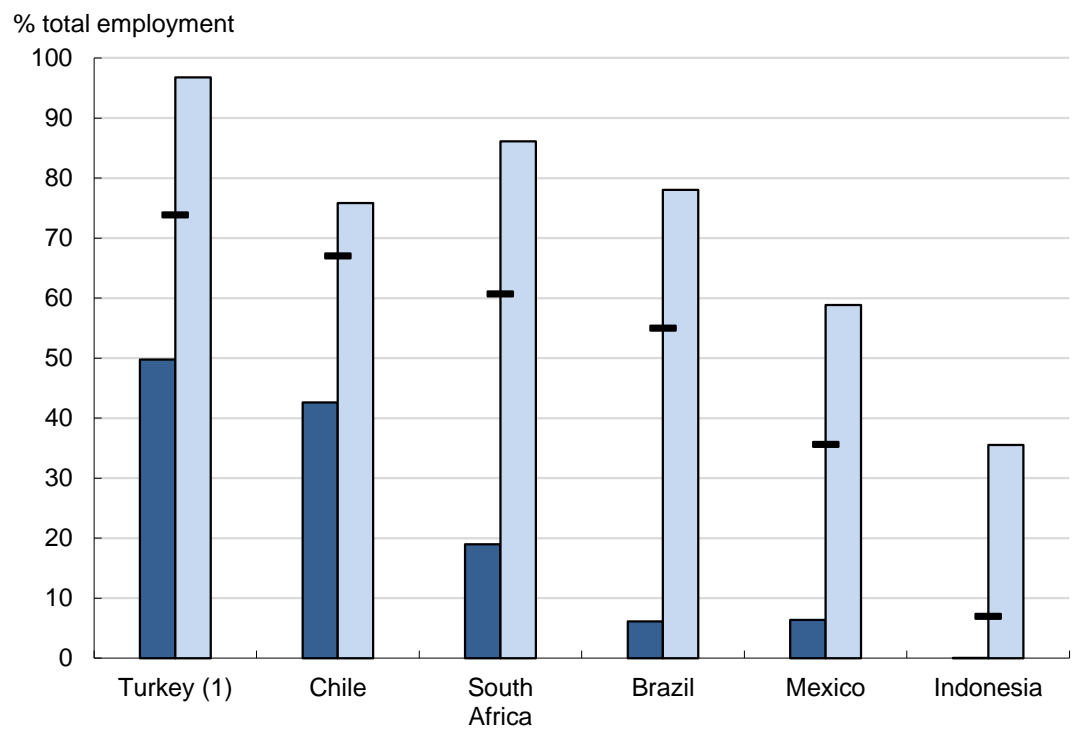

1. Data refer to salaried workers only.

Source: OECD (2011), OECD Employment Outlook 2011.

StatLink ज्ञाजा http://dx.doi.org/10.1787/888933080903 


\section{BIBLIOGRAPHY}

Andersen, T. M. and M. Svarer (2007), "Flexicurity - Labour Market Performance in Denmark", CESifo Economic Studies.

Andersen, T. M. (2012). Collective Risk Sharing: The Social Safety Net and Employment. School of Economics and Management, Aarhus University.

Antolín, P. (2007), "Longevity Risk and Private Pensions", OECD Working Papers on Insurance and Private Pensions, No. 3, OECD Publishing, Paris. doi:10.1787/261260613084

Antolín, P., A. De Serres, and C. de la Maisonneuve (2004), "Long-Term Budgetary Implications of TaxFavoured Retirement Plans", OECD Economics Department Working Papers, No. 393, OECD Publishing, Paris.

Antolin, P., S. Payet and J. Yermo (2010), "Assessing Default Investment Strategies in Defined Contribution Pension Plans", OECD Journal: Financial Market Trends, Vol. 2010/1, OECD Publishing, Paris. doi: $\underline{10.1787 / f m t-2010-5 k m 7 k 9 t p 4 b h b}$

Barr, N. (2012), Economics of the Welfare State, Oxford University Press.

Bassanini, A. and R. Duval (2006), "Employment Patterns in OECD Countries: Reassessing the Role of Policies and Institutions", OECD Social, Employment and Migration Working Papers, No. 35, OECD Publishing, Paris.

doi: $10.1787 / 702031136412$

Baumol, W. J. (1996), "Children of Performing Arts, the Economic Dilemma: The Climbing Costs of Health Care and Education", J Cult Econ, Vol. 20(3), 183-206.

Boeri, T, and H. Bruecker (2011), "Short-time Work Benefits Revisited: Some Lessons from the Great Recession”, Economic Policy, Vol. 26, No. 68, pp. 697-765.

Brown, J. R., and A. Finkelstein (2007), "Why Is the Market for Long-Term Care Insurance so Small?", Journal of Public Economics, Vol. 91(10), 1967-1991.

Chetty, R. and A. Finkelstein (2012), "Social Insurance: Connecting Theory and Data", NBER Working Paper, No. 18433.

Cooper, Z., S. Gibbons, S. Jones, and A. McGuire (2011), "Does Hospital Competition Save Lives? Evidence from the English NHS Patient Choice Reforms", The Economic Journal, Vol. 121(554), F228-F260.

Cournède, B., A. Goujard and Á. Pina (2013), "How to Achieve Growth- and Equity-friendly Fiscal Consolidation? A Proposed Methodology for Instrument Choice with an Illustrative Application to OECD Countries", OECD Economics Department Working Papers, No. 1088, OECD Publishing, Paris.

doi: $\underline{10.1787 / 5 k 407 l w v z k k h-e n}$

Curristine, T., J. Harris and J. Seiwald (2013), "Case Studies of Fiscal Council - Functions and Impact", IMF Policy Paper, July 2013. 
D'Addio, A. C., J. Seisdedos and E. R. Whitehouse (2009), "Investment Risk and Pensions: Measuring Uncertainty in Returns", OECD Social, Employment and Migration Working Papers, No. 70, OECD Publishing, Paris. doi: $10.1787 / 224016838064$

Darby, J. and J. Melitz (2008), “Social Spending and Automatic Stabilizers in the OECD”, Economic Policy, Vol. 23(56), 715-756, October.

De Serres, A., F. Murtin and C. de la Maisonneuve (2012), "Policies to Facilitate the Return to Work", Comparative Economic Studies, Vol. 54/1, pp. 5-42.

Docteur, E. and H. Oxley (2003), "Health-Care Systems: Lessons from the Reform Experience”, OECD Health Working Papers, No. 9, OECD Publishing, Paris. doi: $10.1787 / 865047648066$

Fall, F. and N. Ferrari (2008), "The Outlook for Pension Spending and the Role of a Reserve Fund”, Tresor-Economics, n. 39.

Fall, F. et al. (2014), "Vulnerability of Social Instiutions: Lessons from the Recent Crisis and Historical Episodes”, OECD Economics Department Working Papers, No. 1130, OECD Publishing, Paris.

Fall, F. and D. Bloch (2014), "Overcoming Vulnerabilities of Pension Systems”, OECD Economics Department Working Papers, No. 1133, OECD Publishing, Paris.

Fall, F. (2014), "A Framework of Comparing the Robustness of PAYG Pension Schemes", OECD Economics Department Working Papers, No. 1134, OECD Publishing, Paris.

Gaynor, M., R. Moreno-Serra and C. Propper (2013), "Death by Market Power: Reform, Competition, and Patient Outcomes in the National Health Service", American Economic Journal: Economic Policy, Vol. 5(4), 134-166.

van Ginneken, E., K. Swartz and P. Van der Wees (2013), "Health Insurance Exchanges in Switzerland and the Netherlands Offer Five Key Lessons for the Operations of US Exchanges", Health Affairs, 32(4).

Hagemann, R. (2011), "How Can Fiscal Councils Strengthen Fiscal Performance?”, OECD Journal: Economic Studies, Vol. 2011/1, OECD Publishing, Paris. doi: $10.1787 /$ eco studies-2011-5kg2d3gx4d5c

Heady, C. (2013), "The Effects of Ageing on the Financing of Social Health Provision", Paper presented at the 2nd Meeting of the Joint Network on Fiscal Sustainability of Health Systems, 26 March, OECD, Paris.

Holzmann, R. and S. Jorgensen (2001), "Social Risk Management: A Conceptual Framework for Social Protection, and Beyond”, International Tax and Public Finance, Vol. 8, pp. 529-556.

Holzmann, R., J. Koettl and T. Chernetsky (2005), "Portability Regimes of Pension and Health Care Benefits for International Migrants: an Analysis of Issues and Good Practices”, Social Protection Discussion Papers, No. 32750, The World Bank.

Hribernik, M. and R. Kierzenkowski (2013), “Assessing the Efficiency of Welfare Spending in Slovenia with Data Envelopment Analysis", OECD Economics Department Working Papers, No. 1058, OECD Publishing, Paris. doi: $10.1787 / 5 \mathrm{k} 44 \mathrm{v} 5373 \mathrm{q} 0 \mathrm{q}$-en

Johnson, R.W. and C.E. Uccello (2005), “Is Private Long-Term Care Insurance the Answer?”, Tax Policy Centre, available at www.taxpolicycenter.org/UploadedPDF/1000795.pdf 
Joumard, I., P. Hoeller, C. André and C. Nicq (2010), Health Care Systems: Efficiency and Policy Settings, OECD Publishing, Paris. doi: $\underline{10.1787 / 9789264094901-e n}$

Kessler, D. P. and M. B. McClellan (2000), "Is Hospital Competition Socially Wasteful?", The Quarterly Journal of Economics, Vol. 115(2), 577-615.

Martin, J.P. and E. Whitehouse (2008), "Reforming Retirement-Income Systems: Lessons from the Recent Experiences of OECD Countries”, IZA Discussion Paper, No. 3521.

de la Maisonneuve C., R. Moreno-Serra, F. Murtin and J. Oliveira Martins (2014), "Health Systems, Institutions and Health Expenditure Drivers", OECD Economics Department Working Papers, forthcoming.

de la Maisonneuve, C. and J. Oliveira Martins, J. (2013), "A Projection Method for Public Health and Long-term Care Expenditures", OECD Economics Department Working Papers, No. 1048, OECD Publishing, Paris.

OECD (2009), Pensions at a Glance 2009: Retirement-Income Systems in OECD Countries, OECD Publishing, Paris. doi: 10.1787/pension glance-2009-en

OECD (2010), "Making Reform Happen, Lessons from OECD Countries", OECD Publishing, Paris. doi: 10.1787/9789264086296-en

OECD (2011a), OECD Employment Outlook 2011, OECD Publishing, Paris. doi: $10.1787 / \mathrm{empl}$ outlook-2011-en

OECD (2011b), OECD/IOPS Good Practices for Pension Funds' Risk Management Systems, OECD Publishing, http://www.oecd.org/site/iops/principlesandguidelines/46864307.pdf

OECD (2012a), Settling In: OECD Indicators of Immigrant Integration 2012, OECD Publishing, Paris. doi: $10.1787 / 9789264171534-e n$

OECD (2012b), OECD Pensions Outlook 2012, OECD Publishing, Paris. doi: 10.1787/9789264169401-en.

OECD (2012c), OECD Economic Surveys: Finland 2012, OECD Publishing, Paris. doi: $10.1787 /$ eco surveys-fin-2012-en

OECD (2013a), OECD Employment Outlook 2013, OECD Publishing, Paris. doi: $10.1787 / \mathrm{empl}$ outlook-2013-en

OECD (2013b), Pensions at a Glance 2013: OECD and G20 Indicators, OECD Publishing, Paris. doi: 10.1787/pension_glance-2013-en.

OECD (2013c), Pension Markets in Focus 2013, OECD Publishing, Paris. www.oecd.org/finance/PensionMarketsInFocus2013.pdf

OECD (2014), "Policy Challenges for the Next 50 Years", OECD Economics Department Working Papers, No. 9, OECD Publishing, Paris.

Pareliussen, J. (2014), “Overcoming Vulnerabilities of Unemployment Insurance Schemes", OECD Economics Department Working Papers, No. 1131, OECD Publishing, Paris.

Paris, V., M. Devaux and L. Wei (2010), "Health Systems Institutional Characteristics: A Survey of 29 OECD Countries", OECD Health Working Papers, No. 50, OECD Publishing, Paris. 
Pisu, M. (2014), “Overcoming Vulnerabilities of Health Care Systems”, OECD Economics Department Working Papers, No. 1132, OECD Publishing, Paris.

PBGC (Pension Benefit Guaranty Corporation) (2012), “Annual Report 2012: Excellence in Customer Service", Washington D.C.

Raftery, J. and J. Powell (2013), "Health Technology Assessment in the UK”, The Lancet, Vol. 382(9900), 1278-1285.

Sassi, F., A. Belloni and C. Capobianco (2013), "The Role of Fiscal Policies in Health Promotion," OECD Health Working Papers, No. 66, OECD Publishing, Paris. doi: $10.1787 / 5 \mathrm{k} 3$ twr94kvzx-en

Stewart, F. (2007), "Benefit Security Pension Fund Guarantee Schemes", OECD Working Papers on Insurance and Private Pensions, No. 5, OECD Publishing, Paris. doi: $10.1787 / 260604113335$

Stuckler, D. and Basu, S. (2013), The Body Economic, Basic Books.

Sutherland, D. and P. Hoeller (2014), "Growth Policies and Macroeconomic Stability", OECD Economic Policy Papers, No. 8, OECD Publishing, Paris. doi: 10.1787/5jz8t849335d-en

Tapay, N. and F. Colombo (2004), "Private Health Insurance in OECD Countries: The Benefits and Costs for Individuals and Health Systems", in OECD, Towards High-Performing Health Systems, The OECD Health Project, OECD Publishing, Paris. doi: 10.1787/9789264015562-en

Toder, E.J., B.H. Harris and K. Lim (2009), “Distributional Effects of Tax Expenditures”, Tax Policy Centre Discussion Paper, the Urban-Brookings Tax Policy Institute, www.taxpolicycenter.org/UploadedPDF/ 411922_expenditures.pdf.

Tompson, W. (2009), The Political Economy of Reform: Lessons from Pensions, Product Markets and Labour Markets in Ten OECD Countries, OECD Publishing, Paris.

Wagstaff, A. (2010), “Social Health Insurance Reexamined”, Health Economics, Vol. 19 (5), 503-517.

Wilsford, D. (1994), "Path Dependency, or Why History Makes it Difficult but not Impossible to Reform Health Care Systems in a Big Way", Journal of Public Policy, Vol. 14(3), 251-283.

Wyplosz, C (2012), "Fiscal Rules: Theoretical Issues and Historical Experiences”, NBER Working Paper No 17884.

Yoo, K. and A. De Serres (2004), "Tax Treatment of Private Pension Savings in OECD Countries", OECD Economic Studies, Vol. 39(2), pp 73-110, OECD Publishing, Paris. 


\section{APPENDIX}

Table A1. Social spending before and after the crisis

As a percentage of GDP

\begin{tabular}{|c|c|c|c|c|c|c|c|c|c|c|}
\hline & \multicolumn{2}{|c|}{$\begin{array}{l}\text { Old age and } \\
\text { survivors } \\
\text { pensions }\end{array}$} & \multicolumn{2}{|c|}{ Health } & \multicolumn{2}{|c|}{$\begin{array}{l}\text { Unemployment } \\
\text { and active labour } \\
\text { market } \\
\text { programmes }\end{array}$} & \multicolumn{2}{|c|}{ Other } & \multicolumn{2}{|c|}{ Total } \\
\hline & $\begin{array}{l}\text { Pre- } \\
\text { crisis }\end{array}$ & $\begin{array}{c}\text { Most } \\
\text { recent }\end{array}$ & $\begin{array}{l}\text { Pre- } \\
\text { crisis }\end{array}$ & $\begin{array}{c}\text { Most } \\
\text { recent }\end{array}$ & $\begin{array}{l}\text { Pre- } \\
\text { crisis }\end{array}$ & $\begin{array}{c}\text { Most } \\
\text { recent }\end{array}$ & $\begin{array}{l}\text { Pre- } \\
\text { crisis }\end{array}$ & $\begin{array}{c}\text { Most } \\
\text { recent }\end{array}$ & $\begin{array}{l}\text { Pre- } \\
\text { crisis }\end{array}$ & $\begin{array}{c}\text { Most } \\
\text { recent }\end{array}$ \\
\hline Australia & 5.7 & 5.6 & 6.0 & 6.3 & 0.4 & 0.5 & 4.8 & 5.4 & 16.9 & 17.9 \\
\hline Austria & 12.6 & 14.0 & 6.7 & 7.3 & 0.9 & 1.1 & 6.8 & 7.6 & 27.1 & 30.0 \\
\hline Belgium & 9.0 & 10.2 & 7.0 & 8.1 & 3.2 & 3.7 & 6.8 & 7.7 & 26.0 & 29.7 \\
\hline Canada & 4.1 & 4.4 & 6.9 & 7.9 & 0.6 & 0.8 & 5.3 & 5.5 & 16.8 & 18.6 \\
\hline Chile & 6.1 & 4.6 & 2.8 & 3.6 & 0.0 & 0.1 & 1.7 & 1.3 & 10.7 & 9.5 \\
\hline Czech Republic & 7.6 & 9.0 & 5.6 & 6.7 & 0.6 & 1.0 & 4.6 & 4.6 & 18.4 & 21.3 \\
\hline Denmark & 7.3 & 8.2 & 6.7 & 7.7 & 2.0 & 2.4 & 10.7 & 12.2 & 26.7 & 30.4 \\
\hline Estonia & 5.2 & 8.0 & 3.8 & 5.1 & 0.1 & 1.1 & 3.5 & 5.8 & 12.7 & 20.0 \\
\hline Finland & 9.2 & 11.2 & 5.9 & 6.8 & 1.6 & 2.0 & 8.0 & 9.4 & 24.7 & 29.4 \\
\hline France & 13.1 & 14.3 & 8.7 & 9.0 & 1.4 & 1.6 & 7.0 & 7.6 & 30.1 & 32.4 \\
\hline Germany & 10.6 & 10.9 & 7.7 & 8.5 & 1.4 & 1.6 & 6.5 & 6.1 & 26.2 & 27.1 \\
\hline Greece & 12.1 & 13.2 & 5.9 & 6.5 & 0.5 & 0.7 & 3.1 & 3.4 & 21.6 & 23.9 \\
\hline Hungary & 9.7 & 10.4 & 5.1 & 5.1 & 0.7 & 0.9 & 7.5 & 7.5 & 23.0 & 23.9 \\
\hline Iceland & 2.3 & 2.2 & 5.7 & 6.2 & 0.2 & 1.7 & 8.5 & 9.8 & 16.8 & 19.9 \\
\hline Ireland & 3.9 & 5.8 & 5.9 & 6.3 & 1.0 & 2.6 & 5.9 & 9.0 & 16.7 & 23.7 \\
\hline Israel & 4.9 & 5.0 & 3.8 & 3.9 & 0.3 & 0.3 & 6.5 & 6.6 & 15.5 & 15.8 \\
\hline Italy & 15.2 & 16.8 & 6.6 & 7.4 & 0.5 & 0.8 & 4.0 & 4.4 & 26.3 & 29.4 \\
\hline Japan & 10.6 & 12.3 & 6.2 & 7.3 & 0.3 & 0.3 & 2.3 & 2.5 & 19.5 & 22.3 \\
\hline Korea & 2.3 & 3.1 & 3.6 & 4.2 & 0.3 & 0.4 & 2.2 & 1.5 & 8.4 & 9.2 \\
\hline Luxembourg & 6.6 & 8.1 & 6.0 & 7.0 & 0.9 & 1.3 & 7.2 & 8.1 & 20.6 & 24.4 \\
\hline Mexico & 1.3 & 1.8 & 2.6 & 2.7 & 0.0 & 0.0 & 3.0 & 3.1 & 6.9 & 7.7 \\
\hline Netherlands & 5.6 & 6.0 & 7.0 & 7.9 & 1.2 & 1.5 & 8.1 & 8.4 & 21.8 & 23.8 \\
\hline New Zealand & 4.3 & 4.7 & 7.1 & 8.4 & 0.2 & 0.5 & 6.9 & 7.6 & 18.6 & 21.2 \\
\hline Norway & 6.4 & 7.3 & 5.6 & 6.1 & 0.2 & 0.4 & 9.5 & 10.9 & 21.7 & 24.8 \\
\hline Poland & 10.7 & 11.9 & 4.5 & 5.2 & 0.3 & 0.3 & 4.2 & 4.2 & 19.7 & 21.5 \\
\hline Portugal & 10.8 & 12.5 & 6.7 & 7.2 & 1.2 & 1.2 & 4.4 & 4.9 & 23.1 & 25.8 \\
\hline Slovak Republic & 6.3 & 7.4 & 5.2 & 6.0 & 0.4 & 0.7 & 4.1 & 4.7 & 15.9 & 18.8 \\
\hline Slovenia & 9.7 & 10.9 & 5.6 & 6.8 & 0.3 & 0.5 & 3.8 & 4.4 & 19.5 & 22.6 \\
\hline Spain & 8.5 & 9.9 & 6.1 & 7.0 & 1.8 & 3.5 & 4.9 & 5.6 & 21.3 & 26.0 \\
\hline Sweden & 9.5 & 10.7 & 6.5 & 7.3 & 0.7 & 0.8 & 11.0 & 11.4 & 27.7 & 30.2 \\
\hline Switzerland & 12.2 & 11.9 & 5.4 & 5.8 & 0.6 & 0.5 & 7.5 & 7.2 & 25.7 & 25.4 \\
\hline Turkey & 6.2 & 6.9 & 4.1 & 5.4 & 0.0 & 0.1 & 0.1 & 0.4 & 10.5 & 12.8 \\
\hline United Kingdom & 6.4 & 7.4 & 6.8 & 8.0 & 0.4 & 0.7 & 7.7 & 8.9 & 21.2 & 25.0 \\
\hline United States & 5.7 & 6.6 & 7.2 & 8.3 & 0.3 & 1.1 & 3.4 & 3.9 & 16.6 & 19.9 \\
\hline
\end{tabular}

Note: Pre-crisis refers to 2007 for all countries. Most recent refers to 2011 for Chile, Israel and Mexico; to 2010 for Australia, Canada, Germany, Ireland, Japan, Korea, New Zealand and the United States; to 2008 for Switzerland; and to 2009 for all other countries. Data refer to public and mandatory private expenditures. Other spending includes family, housing and incapacityrelated spending.

Source: OECD Social Expenditure database and OECD Economic Outlook database, accessed 9 January 2014. 